UNIVERSIDADE DE SÃO PAULO

INSTITUTO DE FÍSICA, INSTITUTO DE QUÍMICA, INSTITUTO DE BIOCIÊNCIAS, FACULDADE DE EDUCAÇÃO

VICTOR ALEXANDRE ALVES DE CARVALHO

PESQUISAS NA INTERFACE ENTRE HISTÓRIA DA CIÊNCIA E ENSINO DE CIÊNCIAS: ANALISANDO AS FONTES DE DADOS HISTÓRICOS NA PRODUÇÃO DO PIEC 


\title{
PESQUISAS NA INTERFACE ENTRE HISTÓRIA DA CIÊNCIA E ENSINO DE CIÊNCIAS: ANALISANDO AS FONTES DE DADOS HISTÓRICOS NA PRODUÇÃO DO PIEC
}

\author{
Versão Original
}

Dissertação de mestrado apresentada ao Programa de PósGraduação Interunidades em Ensino de Ciências do Instituto de Física, Instituto de Química, Instituto de Biociências e à Faculdade de Educação da Universidade de São Paulo, para obtenção do título de Mestre em Ensino de Ciências.

Orientadora: Profa $^{a}$. Dra ${ }^{\mathrm{a}}$. Valéria Silva Dias

São Paulo 


\section{FICHA CATALOGRÁFICA \\ Preparada pelo Serviço de Biblioteca e Informação do Instituto de Física da Universidade de São Paulo}

Carvalho, Victor Alexandre Alves de

Pesquisas na interface entre história da ciência e ensino de ciências: analisando as fontes de dados históricos na produção do PIEC. São Paulo, 2021.

Dissertação (Mestrado) - Universidade de São Paulo. Faculdade de Educação, Instituto de Física, Instituto de Química e Instituto de Biociências.

Orientador: Profa. Dra. Valéria Silva Dias

Área de Concentração: Ensino de Física.

Unitermos: 1. Física - Estudo e ensino; 2. Fontes históricas; 3. História da Ciência; 4. Ensino. 


\section{AGRADECIMENTOS}

Agradeço ao meu pai, Márcio, que me ensinou a questionar e a sempre querer buscar mais. Sinto sua falta! Agradeço também à minha mãe, lone, pelo seu incondicional e imensurável carinho. Dálite, minha irmã, te agradeço imensamente pelo seu companheirismo! Agradeço a toda minha família pelo suporte e pela motivação.

Meus sinceros agradecimentos a todos meus amigos que ofereceram importantíssimos momentos de conversa. Vocês tornaram essa caminhada muito mais fácil!

Agatha, obrigado pela paciência para ouvir meus desabafos e pelos momentos de conversa ao longo desses anos. Seu amor tornou muitas coisas possíveis.

Agradeço minha orientadora, Valéria, pelos ensinamentos e aconselhamentos. Obrigado pela paciência e por me motivar a zelar pelo meu desejo de ser professor. Agradeço também ao grupo de pesquisa onde surgiram vários debates frutíferos e interessantes, sempre com um clima de amizade!

Agradeço ao professor Breno Moura e à professora Lilian Martins pelas valiosas contribuições durante o exame de qualificação. Vocês me deram confiança pra continuar nessa jornada.

Agradeço aos meus colegas do Colégio Britânico pelas trocas de ideias e momentos de risada. Obrigado pelo espaço para me desenvolver profissionalmente e aplicar o que aprendi durante a graduação.

Por fim, agradeço também a todos os professores do Instituto Federal de São Paulo e da Universidade de São Paulo que deram, cada um de seu jeito, importantes contribuições através das disciplinas ministradas. 


\section{RESUMO}

CARVALHO, Victor A. A de. Pesquisas na Interface entre História da Ciência e Ensino de Ciências: analisando as Fontes de Dados Históricos na Produção do PIEC. Dissertação (Mestrado em Ensino) - Instituto de Física, Instituto de Química, Instituto de Biociências, Faculdade de Educação - Programa Interunidades em Ensino de Ciências, Universidade de São Paulo, 2021.

Analisando o desenvolvimento da área de pesquisa em Ensino de Ciências no Brasil, trajeto iniciado com os projetos de ensino e consolidado com o estabelecimento de programas de pós-graduação, é possível notar que há um constante interesse temático pela História da Ciência. Nota-se, então, a existência de uma interface entre a pesquisa em Ensino e a História das Ciências, que foi se modificando ao longo dos anos. A produção de trabalhos com esta interface tem como uma das mais importantes formas de registro as teses e dissertações produzidas dentro dos programas de pós-graduação em Ensino de Ciências. O objetivo da pesquisa que aqui se apresenta é examinar um aspecto específico da produção de um dos programas pioneiros da área, o Programa de Pós-Graduação Interunidades em Ensino de Ciências da Universidade de São Paulo (PIEC). Para guiar nossa pesquisa, formulamos a seguinte pergunta: "Quais são as fontes históricas e como elas têm sido utilizadas nas dissertações e teses produzidas no âmbito do PIEC?". O nosso trajeto em busca da resposta passou por um estudo da história da área e por um estudo de questões relevantes para a historiografia da ciência, como algumas referentes ao internalismo e externalismo e algumas referentes ao uso de fontes historiográficas em pesquisas. Consideramos as fontes como discursos produzidos em condições específicas e, de modo pontual, apresentamos os gêneros discursivos bakhitinianos para dar suporte a essa escolha. Utilizando uma metodologia tanto quantitativa quanto qualitativa, concluímos que as teses e dissertações do programa, da modalidade Física, apresentam uma abordagem mais próxima do internalismo e utilizam, predominantemente, fontes secundárias de dados históricos. Concluímos também que os autores dão pouca atenção ao registro de informações sobre as formas de acesso às fontes históricas e que essas fontes têm nas teses e dissertações, quase que exclusivamente, um papel voltado à metodologia historiográfica.

Palavras-chave: Pesquisa em Ensino de Ciências. História da Ciência. Fontes Históricas, Programa de Pós-Graduação Interunidades em Ensino de Ciências. 


\begin{abstract}
CARVALHO, Victor A. A. de. Researches in the interface between History of Science and Science Teaching: Analyzing the Historical Sources in PIEC's Production. Dissertation (Master in Science Education) - Physics Institute, Chemistry Institute, Biosciences Institute, Education College, University of São Paulo, 2021.

Analyzing the development of the area of science teaching in Brazil, that is started with teaching projects and consolidated with the creation and establishment of postgraduate programs, it is possible to notice that there is a constant thematic interest in the History of Science. There is, therefore, the existence of an interface between research about the area science teaching and the area of history of science. This interaction has been modified through the years. The objective with this research is to explore one specific aspect of one of the pioneering programs in this area, the PósGraduação Interunidades em Ensino de Ciências at the University of São Paulo. To conduct this research, we formulated this question: "What are the historical sources and how are they being used in dissertations and theses produced inside this program?". Our path to discover an answer for this question started with research into the history of the area and about some of the issues related to historiography of science, such as the use of sources and different definitions of internalism and externalism. We understood these sources as speeches created inside specific conditions and briefly explored Bakhtin's ideas to support our choice. Using both quantitative and qualitative methodology, we concluded that the materials analyzed, about Physics Teaching, show an internalist approach and use, predominantly, secondary historical sources. We also concluded that the authors are not very strict about recording the sources and their access. Our last conclusion was about the role of the historical sources in these productions: they are mostly used as part of historical methodology, with no proposals about science teaching.
\end{abstract}

Keywords: Research in Science Teaching, History of Science, Historical Sources, Interunidades em Ensino de Ciências Post-Graduate Program. 


\section{SUMÁRIO}

INTRODUÇÃO

1. A ÁREA DE ENSINO DE CIÊNCIAS: UM PANORAMAHISTÓRICO DO DESENVOLVIMENTO DA ÁREA NO BRASIL. 11

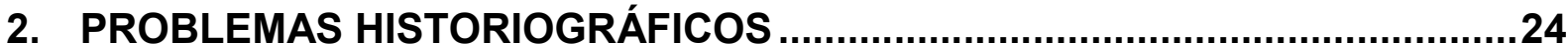

2.1 Relativismo e dogmatismo: mudanças na historiografia da ciência....................24

2.2 Internalismo e externalismo: a abordagem temática .....................................28

2.3 Fontes na historiografia da ciência: dimensões e definições ............................32

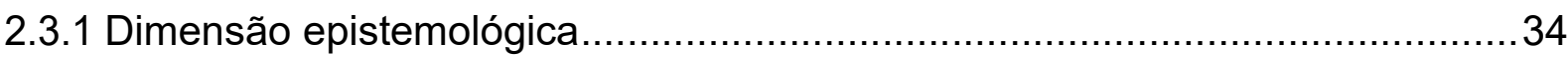

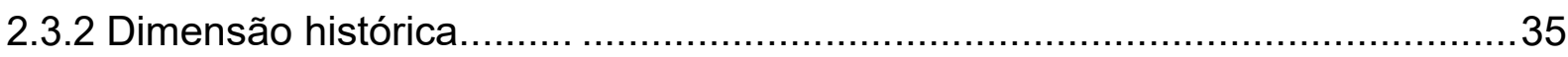

2.3.2.1 Bakhtin e a concepção dialógica da linguagem ...................................... 36

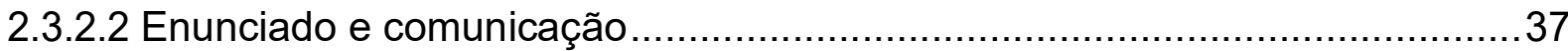

2.3.2.3 Os gêneros discursivos de Bakhtin ...................................................38

2.3.3 Dimensão prática ............................................................................... 41

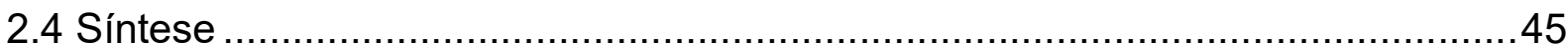

3. PERCURSO DE PESQUISA E METODOLOGIA ...........................................46

3.1 Dimensões de análise, categorias e índices ...........................................49

4. APRESENTAÇÃO E ANÁLISE DE DADOS ...............................................52

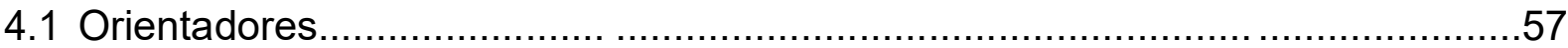

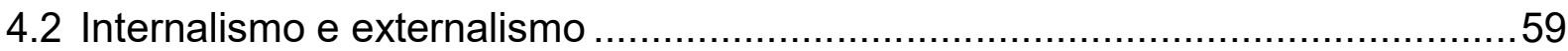

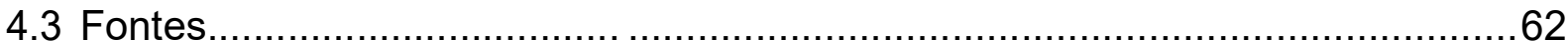

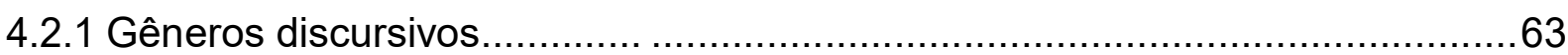

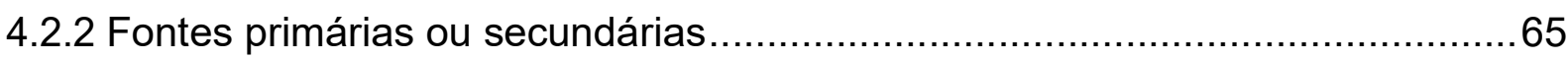

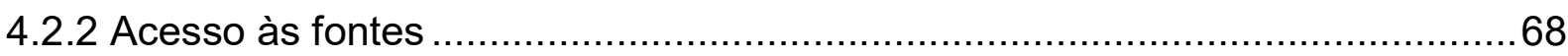

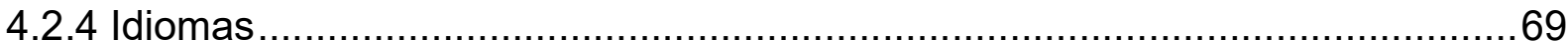

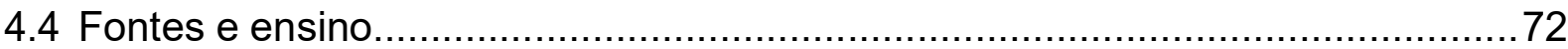

5. CONCLUSÃO: CARACTERIZAÇÃO DE UM ASPECTO DO PROGRAMA......74

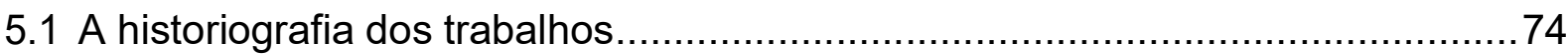

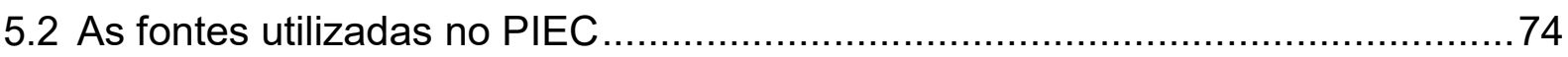

APÊNDICE A - TRABALHOS DO PIEC NA INTERFACE ENTRE HISTÓRIA DA

CIÊNCIA E ENSINO .80

APÊNDICE B - TRABALHOS ANALISADOS PARA A CONSTRUÇÃO DESSE

TRABALHO. 


\section{INTRODUÇÃO}

Esse trabalho tem como ponto de partida - e mais profunda inspiração - a história da ciência. Representa a busca por respostas e preocupações específicas sobre o desenvolvimento histórico da ciência e, principalmente, sobre como a escrita da história da ciência é feita e entendida.

Chegamos ao projeto de pesquisa e ao desenvolvimento desse trabalho motivados pelo papel que a história da ciência pode ter no ensino de ciências. Nesse sentido, buscamos explorar essa temática mantendo em mente um norte, uma pergunta que nos orientou, e que representa, de alguma forma, a contribuição que desejamos dar ao ensino de ciências: Quais são as fontes de dados históricos e como elas têm sido utilizadas nas pesquisas em Ensino de Ciências?

Responder a essa pergunta envolve a análise da utilização de "fontes históricas", que formam uma importante base para o trabalho historiográfico, tão caro a nós no decorrer da trajetória de pesquisa. Como veremos, há uma série de problemáticas envolvendo o uso de dados históricos, que vão desde a obtenção desses materiais até os diversos entendimentos possíveis sobre eles.

Para tornar a investigação possível, fizemos um recorte no qual decidimos analisar parte das dissertações e teses produzidas no âmbito do Programa Interunidades em Ensino de Ciências (PIEC), que também abriga esse trabalho. $O$ PIEC é um dos mais antigos programas de pós-graduação em Ensino de Ciências, abrigando um grande número de teses e dissertações. Além disso, desde seu início, abriga trabalhos que articulam história da ciência e ensino de ciências.

Com isso definimos a pergunta principal da pesquisa como: Quais são as fontes de dados históricos e como elas têm sido utilizadas nas teses e dissertações produzidas no âmbito do Programa Interunidades em Ensino de Ciências (PIEC)?

Para responder nossa pergunta buscamos, em primeiro lugar, identificar a composição das fontes históricas utilizadas em história da ciência nesses trabalhos. São utilizadas cartas? São utilizados artigos? Outros textos históricos? Há predominância no uso de algum determinado tipo de material?

Também fizemos um movimento de caracterizar essas fontes como fontes primárias ou fontes secundárias. É alta a incidência do uso de fontes primárias?

Em terceiro lugar, buscamos compreender como se dá o acesso às fontes de dados históricos. Como são selecionadas as fontes primárias e secundárias? 
Conforme afirma Martins (2005), há uma problemática importante para o historiador da ciência que envolve o contato com materiais diversos, de línguas diversas e que nem sempre são obtidos para consulta com facilidade. Como as fontes são acessadas? Existem dificuldades de acesso? Essas questões são explicitadas nas teses e dissertações do programa?

Por último, após explorar esse conjunto de questões, refletimos sobre o papel dessas fontes na produção do PIEC. São elas apresentadas como recursos didáticos para aulas de ciências? Como materiais para formação complementar dos professores?

Para buscar respostas para essas questões, interpretamos as fontes como manifestações dialógicas. Entendemos, a partir das discussões promovidas por Bakhtin (2017), que a ciência, a historiografia da ciência e o ensino envolvem o uso da linguagem na forma de diálogo.

Nesse sentido, um artigo, por exemplo, pode refletir intenções de um cientista de comunicar aos seus pares o produto de sua pesquisa. Há, então, um movimento comunicativo nessa publicação científica. O mesmo artigo pode ser uma fonte primária de dados históricos, por meio do trabalho de um historiador da ciência (KRAGH, 1987), que também se comunica de alguma forma: ele interpreta o significado desse artigo e constrói um relato com base nesse material.

Para estruturar a dissertação, começamos no capítulo 1, investigando os eventos do estabelecimento da área de Ensino de Ciências no Brasil, entendendo, principalmente, os momentos de inserção da história da ciência nessa trajetória. Esse movimento foi importante para entender a origem da interface entre história da ciência e ensino de ciências na pesquisa em ensino e para identificar o PIEC como um dos programas mais longevos da área.

No segundo capítulo apresentamos algumas concepções e discussões historiográficas que consideramos relevantes para uma compreensão melhor da composição de um relato historiográfico. Além disso, também apresentaremos os gêneros discursivos de Bakhtin que suportam nosso modo de entender a composição discursiva das fontes.

No segundo capítulo apresentamos o panorama geral da produção do PIEC que abriga, hoje, teses e dissertações de ensino de física, ensino de química e ensino de biologia. Procuramos quantificar os trabalhos produzidos na interface entre $\mathrm{HC}$ e $E C$, que foram alvo de nossa análise posterior. 
Dando continuidade ao desenvolvimento dessa pesquisa, apresentamos, no capítulo 3, nosso percurso metodológico. Descrevemos, pois, a obtenção dos dados para a análise e a criação das categorias de análise utilizadas.

O capítulo 4 e 5 representam, respectivamente, a análise e a conclusão retirada do conjunto de dados que escolhemos. Nesses dois capítulos expomos os resultados principais desse trabalho, que consistem da percepção de um uso predominante de fontes secundárias, atendendo a uma abordagem próxima do internalismo. 


\section{A ÁREA DE ENSINO DE CIÊNCIAS: UM PANORAMA HISTÓRICO DO DESENVOLVIMENTO DA ÁREA NO BRASIL}

A área do ensino de ciências tem preocupações específicas referentes ao ensino de física, química, biologia e outras disciplinas correlatas. Mas a produção de pesquisa na área se localiza num contexto mais amplo de valorização da ciência, que envolve a necessidade de formar novos cientistas e de comunicar à sociedade os produtos dessa atividade (NARDI, 2005).

É possível, conforme aponta Megid Neto (2014) pensar em duas dimensões do ensino de ciências no Brasil. A primeira delas é a dimensão escolar, manifestada pela presença longeva das disciplinas científicas nos currículos de ensino básico; a segunda é a dimensão acadêmica, que se refere às pesquisas que se desenvolvem sobre a temática específica do ensino das ciências.

Os primeiros passos da pesquisa na área remetem, conforme citam alguns autores (DIAS, 2008; NARDI, 2005), ao início da década de 1960. É possível identificar, nessa época, medidas ligadas diretamente à melhoria do ensino de ciências na escola básica. Posteriormente, a pesquisa começa a se desenvolver, principalmente através dos programas de pós-graduação, institutos específicos, eventos diversos e publicações. Conforme expõe Nardi (2005), diversos fatores influenciaram e promoveram o desenvolvimento da área de Pesquisa em Ensino de Ciências no Brasil. O objetivo desse capítulo, então, é apresentar alguns desses fatores, construindo um panorama histórico da institucionalização da área. Neste panorama, evidenciaremos as contribuições que a história da ciência tem apresentado à história da área, destacando os diversos contornos que essa interação apresenta.

Para tanto, recorremos a materiais de pesquisadores que se preocuparam em entender a história da área. Nesse sentido, destacam-se Nardi (2005), Megid Neto (2014), Villani, Pacca e Freitas (2009) e Dias (2008). Além disso, Dias (2008) também oferece uma contribuição referente à interpretação específica do papel da história da ciência ao longo da história da área. Além desses textos, alguns outros fornecem contribuições pontuais, relevantes por esclarecer alguns aspectos específicos, como Krasilchik (2000) e Pontes (2014).

Segundo Megid Neto (2014), é possível identificar, na segunda metade da 
década de 1940, um "movimento de renovação da educação científica a partir da criação e implementação de projetos curriculares nacionais nas áreas de Ciências da Natureza e Matemática" nos Estados Unidos. Esta época foi marcada pela Guerra Fria, que teve início pouco tempo após o final da Segunda Guerra Mundial (1945) e cujo fim é simbolizado pela separação da União Soviética.

Durante a segunda metade da década de 40, o mundo vivia reflexos dos violentos combates da Segunda Guerra Mundial. Apesar do envolvimento global, destacavam-se duas potências emergentes da Segunda Guerra - os Estados Unidos (EUA) e a União Soviética (URSS). O período do início da Guerra Fria é marcado por certo pessimismo mundial, justificado pela existência de armas nucleares cujo poder de destruição já havia sido testemunhado no Japão em 1945. A URSS havia adquirido um arsenal nuclear em 1949. A principal tensão internacional se encontrava no grande poder de destruição desse tipo de armamento, que colocava em risco a população mundial (HOBSBAWM, 1995).

Podemos ressaltar que um dos acontecimentos mais relevantes, durante 0 decorrer da Guerra Fria, foi o lançamento do satélite Sputnik, pela URSS. No contexto da corrida espacial, esse evento representou um avanço científico importante, dado o pioneirismo científico soviético em relação ao americano. Uma dianteira tecnológica dessa natureza promoveu, nos EUA, uma autocrítica que reconheceu uma deficiência na educação pública. Como resposta os EUA promoveram um forte investimento em instituições científicas (em especial a National Science Foundation) que, por sua vez, promoveram ações visando a melhoria da escola básica (PONTES, 2014; DIAS, 2008). Essas ações, em um primeiro momento, resultaram numa reforma curricular nos EUA.

Surgiu, então, o Physical Science Study Comitee (PSSC), projeto exemplo dos vários produtos de tal reforma. O PSSC apresentava uma visão empirista da ciência, visando a formação de novos cientistas. Houve também outros projetos semelhantes, que atendiam às outras disciplinas e que foram criados na mesma época que o PSSC. $\mathrm{Na}$ Biologia foi criado o BSCS (que já apresentava preocupações explícitas com questões relacionadas à história da ciência); na química, o CBA; na matemática, o SMSG ${ }^{1}$.

1 Biological Science Curriculum Study, Chemical Bond Approach e School Mathematics Study Groups, respectivamente. 
Um movimento semelhante ocorreu na Inglaterra, onde a reforma curricular local produziu o Nuffield Foundation's Science Teaching Project. Esse projeto é decorrente de pesquisas das universidades, fruto da pressão exercida pelos próprios professores de ciências (DIAS, 2008).

Esses projetos influenciaram fortemente a área de ensino de ciências no Brasil, representando um dos fatores que facilitaram o estabelecimento da área. Isso ocorreu por meio de algumas instituições brasileiras que proporcionaram o contato com esses materiais, mediante tradução e treinamento de professores para implementação desses projetos nas escolas de educação básica.

Uma dessas instituições foi o Instituto Brasileiro de Educação, Ciência e Cultura (IBECC), que tinha como objetivo principal levar a ciência à escola básica, além de, posteriormente, traduzir e adaptar materiais estrangeiros para o contexto nacional (MEGID NETO, 2014). Outra instituição importante foi a Fundação Brasileira para o Desenvolvimento do Ensino de Ciências (FUNBEC), criada em 1966 para produzir protótipos de experimentos científicos importados da Europa, de modo a atender o interesse governamental de substituir os produtos importados pelos nacionais. Além desses protótipos, a FUNBEC também produzia manuais para professores e promovia cursos de atualização didática (VILLANI, PACCAS e FREITAS, 2009).

Além dessas instituições, também foram criados, em 1965, os Centros de Ciência, que desempenharam ações relevantes no treinamento de professores (DIAS, 2008).

No contexto da criação dos projetos de ensino destacamos um que promovia a interação da história da ciência com o ensino de ciências: o Projeto Harvard. Esse projeto apresentava uma concepção diferente da empirista presente no PSSC e nos outros projetos da época.

O PSSC foi construído principalmente por especialistas em física, enquanto o Projeto Harvard reuniu esforços de profissionais de diversas áreas. Participaram da composição desse projeto historiadores e filósofos da ciência, físicos, astrônomos, químicos, educadores em ciência, psicólogos e outros profissionais (PENA, 2012). Além disso, o PSSC e a maior parte dos outros projetos visava a formação de cientistas, enquanto o Projeto Harvard se dirigia a um público mais variado, oferecendo discussões sobre aspectos humanísticos, culturais e históricos da ciência. Matthews (1995) aponta que o Projeto Harvard influenciou a produção de alguns materiais nacionais, mas não foi oficialmente implantado no Brasil. Mesmo nos 
Estados Unidos ele teve pouco alcance, atingindo cerca de $15 \%$ dos alunos de $1^{\circ} \mathrm{e}$ $2^{\circ}$ graus (correspondente ao Ensino Fundamental e Médio no Brasil).

Os projetos e as reformas curriculares decorrentes da Segunda Guerra Mundial exemplificam como demandas bem específicas das sociedades moldam características e papéis da escola na esfera social. No caso abordado, podemos inferir que os Estados Unidos promoveram nacionalmente ações de valorização da ciência na esfera educacional em busca de uma supremacia científica mundial.

O Brasil se encontrava no contexto histórico da Segunda Guerra Mundial e do "pós-guerra" numa posição política bastante distinta dos EUA. Segundo Krasilchik (2000), nesta época o Brasil visava o desenvolvimento científico "autóctone", a fim de desenvolver autonomia e independência, em um momento de crescimento industrial, da necessidade de matéria-prima e de produtos industrializados. Acreditamos haver também um contexto favorável para a produção científica em geral e para a valorização do ensino de ciências no Brasil. Um exemplo disso é a promulgação da Lei de Diretrizes e Bases da Educação Nacional de 1961, que previa a ampliação da carga horária das disciplinas de Física, Química e Biologia e a inclusão da disciplina de Ciências já no primeiro ano do ginásio²(KRASILCHIK, 2000). Através da LDB também era incentivado o uso de experimentação nas salas de aula.

Com incentivo da LDB, os projetos de ensino ganharam importância na educação brasileira, porém os resultados da aplicação dos projetos estrangeiros no Brasil não foram satisfatórios (VILLANI, PACCA e FREITAS, 2009; PONTES, 2014). A pouca efetividade na implementação desses projetos se deveu, segundo Villani, Pacca e Freitas (2009), à pouca participação dos professores na construção dos projetos, somada com a baixa apropriação do conteúdo desses materiais. Nos EUA o pouco alcance dos projetos foi devido a fatores semelhantes:

Hoje em dia, parece ser um consenso que uma das causas desse fracasso foi a estratégia de certo modo autocrática que se adotou para se implementarem tais reformas. Durante a concepção e mesmo a implementação dessas últimas, deu-se muita atenção ao que tinham a dizer os chamados grandes especialistas ou autoridades científicas, o que levou até mesmo à inclusão de pesquisadores vencedores de Prêmios Nobel na confecção dos materiais didáticos utilizados nas escolas de nível Fundamental e Médio. Entretanto, faltou em tudo isso

2 Ginásio corresponde ao atual Ensino Fundamental II, assim como Colégio corresponde ao atual Ensino Médio. 
o convencimento, o engajamento e a participação de certos elementos cruciais para o sucesso de qualquer reforma educacional: os professores, que deveriam implementá-la no dia a dia da sala de aula; e também os gestores de nível local, que deveriam zelar para que tais mudanças ocorressem (BROOKE, 2012 apud PONTES, 2014, p.153).

Os projetos de ensino, as mudanças na legislação específica da educação e esforços individuais e institucionais representaram uma parte importante dos fatores que levaram à composição e delineamento da área de Ensino de Ciências no Brasil. A insatisfação com esses projetos, por exemplo, levou à criação de outros projetos, mais adequados à realidade nacional.

Como exemplo, no Instituto de Física da USP foi criado o Projeto de Ensino de Física (PEF). Segundo Villani, Pacca e Freitas (2009, p. 131, tradução nossa),

a ideia era ter um projeto educacional adequado para as condições brasileiras, cujo conteúdo apresentasse o rigor necessário e que adotasse um formato que pudesse ser manuseado pelo próprio estudante, exigindo pouca participação efetiva do professor. $\mathrm{Na}$ época, o projeto também buscou se adaptar às novas políticas educacionais que estavam sendo anunciadas e que [...] reduziram o tempo em que a ciência era estudada e propôs cursos de qualificação mais curtos para os professores de ciências.

Além do PEF, também foi criado o projeto Física Auto-Instrutiva (FAI) que apresentava um material tecnicista, voltado para o desenvolvimento autônomo do aluno, através de exercícios com dificuldade gradualmente crescente. Neste projeto, os autores ressaltam a importância do aluno gerir seu próprio aprendizado, atribuindo ao professor o papel de sanar eventuais dificuldades durante a resolução dos problemas.

Nesse movimento de criação de projetos nacionais, houve um material que apresentou uma interface relevante com a História da Ciência. Se trata do Projeto Brasileiro para o Ensino de Física (PBEF), que foi objeto de estudo na tese de doutorado de Caniato (1973).

Os projetos, portanto, foram parte significativa no contexto de inovações que se instaurava no ensino brasileiro com incentivo da Lei de Diretrizes e Bases de 1961, porém, a Ditadura Militar, iniciada em 1964, promoveu algumas mudanças no sentido oposto. Krasilchik (2000) aponta que a LDB de 1971 (através da lei № 5692 de 11 de agosto de 1971), promulgada durante o regime militar, modificava o papel 
da escola ${ }^{3}$, atribuindo a ela um papel de formação profissional. Consequentemente, o contexto de inovações dá lugar ao investimento em mão de obra.

As disciplinas científicas, portanto, também deveriam atender aos interesses econômicos e políticos do Governo da época. A preocupação com uma formação cidadã e responsável do aluno é substituída pela educação profissional. Fica claro, então, como a educação nessa época é atingida na sua concepção. Um exemplo disso foi que "o projeto de Paulo Freire para a alfabetização e participação sociopolítica foi substituído por um projeto de alfabetização técnica - o MOBRAL" (VILLANI, PACCA e FREITAS, 2009, p. 130, tradução nossa). As ideias de Paulo Freire, segundo esses autores, promoviam uma educação emancipatória, através da qual os estudantes estariam aptos a tomar decisões que interfeririam nas esferas sociais e políticas. A implantação de um projeto tecnicista no lugar de ideias emancipatórias representa um método de controle pelo Governo Militar, visando atender determinados interesses. A educação operava como controle.

Várias concepções de Paulo Freire continuariam a ser invocadas por movimentos estudantis de oposição à Ditadura (VILLANI, PACCA e FREITAS, 2009). Além desses movimentos, as sociedades científicas, nas quais se incluem a Sociedade Brasileira de Física (SBF), Sociedade Brasileira de Química (SBQ) e Sociedade Brasileira para o Progresso da Ciência (SBPC), também oferecem resistência ao regime, principalmente no âmbito da democratização de oportunidades educacionais (DIAS, 2008).

O período da ditadura militar, no que se refere à produção científica em geral nessas décadas, também é marcado pelo controle. Entretanto, ao mesmo tempo em que professores e estudantes de universidades públicas sofriam perseguição, nesse período também é presente o fomento aos programas de pós-graduação (MOTTA, 2014). Ainda assim, as universidades foram pressionadas para restringir suas ações à esfera acadêmica (VILLANI, PACCA e FREITAS, 2007 apud DIAS, 2008).

A LDB havia apontado um papel para o ensino superior no país, que envolvia a formação de pessoal e a pesquisa. No Título IX ("Da Educação de Grau Superior"), Capítulo I, Art. 66, a LDB de 1961 atribui ao ensino superior o papel de realizar pesquisas e desenvolver as ciências, artes e letras, além da formação dos profes-

\footnotetext{
${ }^{3}$ Há uma discussão sobre a natureza dessa lei. Alguns pesquisadores consideram que essa lei não é uma Lei de Diretrizes e Bases. Por fugir do escopo desse trabalho, optamos por não discutirmos detalhes desse debate.
} 
sores de nível universitário. Foi a primeira referência aos cursos de pós graduação na legislação educacional (MEGID NETO, 2014). Além da LDB, outro fator que impulsionou a institucionalização dos cursos de pós-graduação nas universidades brasileiras foi a reforma universitária de 1968, mediante a Lei Federal 5540. De modo geral, essa lei fixa normas de organização do ensino superior no Brasil.

O desenvolvimento da área de EC durante a Ditadura Militar é complexo: ao mesmo tempo em que há o controle e a mudança na concepção da educação no país, é incentivado a criação dos programas de pós-graduação e ações de investimentos na formação dos professores universitários.

Com o fortalecimento dos programas de pós-graduação no âmbito financeiro, dois acontecimentos especialmente importantes para a pesquisa em Ensino de Ciências ocorrem no início da década de 1970: em 1971, é criada, no Instituto de Física da UFRGS, a linha de pesquisa em Ensino de Física; em 1973 é criado o Programa de Pós-Graduação Interunidades em Ensino de Ciências, em uma ação colaborativa entre o Instituto de Física e a Faculdade de Educação da USP.

Além disso, aconteceu, em 1970, o primeiro Simpósio Nacional em Ensino de Física (SNEF), na cidade de São Paulo, promovido pela Sociedade Brasileira de Física. No decorrer desse Simpósio, que contou com a participação de diversos professores de várias regiões do Brasil, foram discutidas as seguintes questões, em formato de sessões específicas:

1) Ensino de Física no Curso Médio;

2) Ensino Médio - Novos Currículos;

3) O curso de Licenciatura em Física;

4) Tecnologia Educacional Moderna;

5) Ensino básico de Física na Universidade;

6) Bacharelado em Física;

7) Pós-graduação e Pesquisa;

Nesta última sessão o enfoque se dirigia a problemas específicos da pósgraduação em Física, já estabelecida no Brasil. São discutidos problemas referentes ao número de mestres e doutores, financiamento, formação dos alunos, pesquisa, etc. A pós-graduação em Ensino de Física, cujo programa surgiria no ano seguinte já se daria no ano seguinte, tinha pouco espaço no evento.

De modo semelhante, outras sociedades científicas também organizaram eventos, como o Encontro de Debates sobre o Ensino de Química (EDEQ, realizado 
no Rio Grande do Sul, no ano de 1980) e o Encontro Nacional de Ensino de Química (ENEQ). A realização dos eventos científicos, conjuntamente com a criação dos primeiros programas de pós-graduação em Ensino de Ciências, indicava a necessidade da sistematização da pesquisa na área (NARDI, 2005). Nesse contexto, um terceiro elemento importante foi a criação de periódicos especializados em Ensino de Ciências.

Nardi (2005) cita os periódicos Cultus, a Revista de Ensino de Ciências (da FUNBEC), a Revista de Ensino de Física (do IFUSP) e o Caderno Catarinense de Ensino de Física (da Universidade Federal de Santa Catarina) como pioneiros nesse ramo da pesquisa e constituintes desse outro importante fator para o estabelecimento da área no Brasil.

Moreira (2000) aponta que o desenvolvimento da área de Ensino de Ciências no Brasil experimentou paradigmas diversos, se encontrando, no ano 2000, em época de ciência normal. Os paradigmas aos quais esse autor se refere às diferentes abordagens feitas no ensino de ciências ao longo da história: primeiramente, investimento nos livros e manuais didáticos; em um segundo momento, investimento nos projetos de ensino (importados e nacionais); o paradigma seguinte é a pesquisa, decorrente, em parte, do insucesso dos projetos na questão da aprendizagem em ciências e outras questões problemáticas em relação ao ensino.

Em seu início, as pesquisas na área podem ser caracterizadas, de modo geral, por apresentarem preocupações imediatas em relação ao ensino, resultando em materiais didáticos (como os projetos nacionais), metodologias de ensino, recursos didáticos, dentre outros. Essas pesquisas, segundo Megid Neto (2014), são conhecidas como "Pesquisa e Desenvolvimento" (P\&D).

Esse tipo de pesquisa parte de um problema específico de pesquisa, cuja causa nem sempre é investigada. A pesquisa, mediante o desenvolvimento de um método (que pode envolver algum material ou metodologia de ensino específica), é feita visando a resolução desse problema. Por fim, há a aplicação do material e discussão sobre seus resultados. (MEGID NETO, 2014).

A estratégia de pesquisa adotada pelo Instituto de Física da UFRGS valorizava o teste de novos métodos de ensino, principalmente pelos novos professores, numa tentativa de solucionar os problemas do ensino de física geral (MOREIRA, 1977 apud NARDI, 2005).

O Instituto de Física da USP, por sua vez, apresentou uma dedicação maior 
aos projetos de ensino. Além do Projeto Piloto da UNESCO, os projetos FAI e PEF foram finalizados no IFUSP, sendo pontos relevantes para a fundação da pósgraduação (DIAS, 2008).

Um pouco posteriormente ao desenvolvimento desses projetos, a pesquisa em ensino de ciências passou a adotar diferentes referenciais teóricos, abrigando uma pluraridade maior em suas abordagens. Um desses movimentos foi 0 das “concepções alternativas", ideia já explorada desde o final da década de 1960. Essas ideias, em conjunto com a noção de aprendizado significativo, representavam um resgate da importância do professor, ao qual seria atribuído um papel ativo nos processos de ensino (VILLANI, PACCA e FREITAS, 2009).

Alguns outros referenciais e métodos de análises foram importantes nessa época inicial das pesquisas em programas de pós-graduação. Dias (2008) analisa esse processo de pesquisa na Universidade de São Paulo:

Estas pesquisas em geral realizavam análises, parciais e sob diferentes aspectos, dos vários projetos produzidos e adotavam sistematicamente como referenciais teóricos: Skinner (principalmente suas ideias sobre condicionamento operante), Keller (principalmente sua proposta de instrução personalizada) e Piaget (principalmente sua teoria dos estágios de desenvolvimento). (DIAS, 2008, p. 24)

Pode-se dizer que a área de ensino de ciências estava em processo de relevante expansão. Dias (2008) aponta que um dos principais fatores desse crescimento é a contribuição de pesquisadores de diversas áreas, acoplando Institutos de Ciências (primeiramente Física e depois Química e Biologia) e as Faculdades de Educação. Ambos serviam, inclusive, como sede para os programas de pesquisa em ensino de ciências.

Ao longo do desenvolvimento da pesquisa em ensino de ciências, é possível notar alguns enfoques importantes, principalmente na questão do nível de ensino ao qual a pesquisa se dirige.

No início dessas pesquisas, uma parte relevante dos trabalhos de pesquisa se dirigia aos cursos de nível superior. Megid Neto (2014) aponta que uma das principais causas desse enfoque foi a ampliação de vagas nas universidades, visando, assim, a melhoria nas disciplinas de física nos cursos de graduação.

Aos poucos, principalmente com o ingresso de professores da educação básica no ensino superior, houve uma ampliação da abordagem dos trabalhos. Pode-se dizer 
que os primeiros trabalhos voltados à escola básica foram de avaliação da aplicação dos projetos nacionais, havendo uma expansão de trabalhos destinados a esse público na década de 1980.

Fazendo uma análise das pesquisas até 2010 percebe-se um enoque maior para o ensino médio, sendo que a porcentagem de trabalhos voltados para o ensino fundamental e educação infantil é menor (MEGID NETO, 2014). O gráfico abaixo apresenta uma aproximação da distribuição dos níveis de escolaridade na pesquisa em ensino de ciências.

Gráfico 1 - Estimativa da Distribuição Percentual por Nível Escolar das Dissertações e Teses Brasileiras em Ensino de Ciências (1972 - 2010)

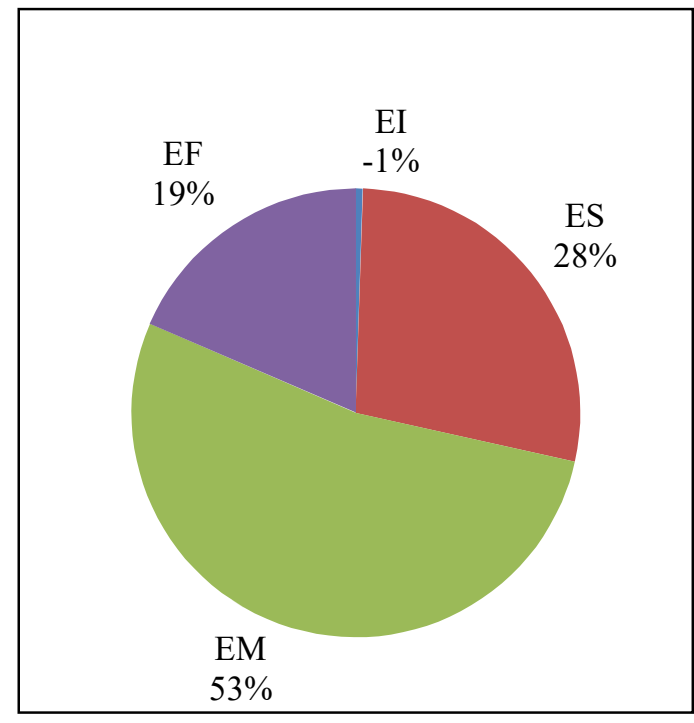

Fonte: MEGID NETO, 2014

Nas décadas seguintes, ao decorrer dos anos 1980 até 2010, a expansão da área é clara. Em nossa interpretação da história da área, destacamos algumas evidências dessa expansão:

- Aumento do número dos programas e cursos de pós-graduação: até o ano 2000 existia um total de sete programas, principalmente, de mestrado. Ao longo do tempo, surgem também os cursos de doutorado e, na década seguinte o número de programas de pós-graduação salta para sessenta (FERES e NARDI, 2014). A formação de doutores em ensino de ciências é muito importante, uma vez que, no início das pesquisas, os mestrandos eram orientados, geralmente, pelos doutores em "ciências duras" ou pelos professores doutores das faculdades de educação. Feres e Nardi (2014) construíram um gráfico que indica o crescimento do número de 
programas da área:

Gráfico 2 - Evolução no número de Programas de Pós-Graduação

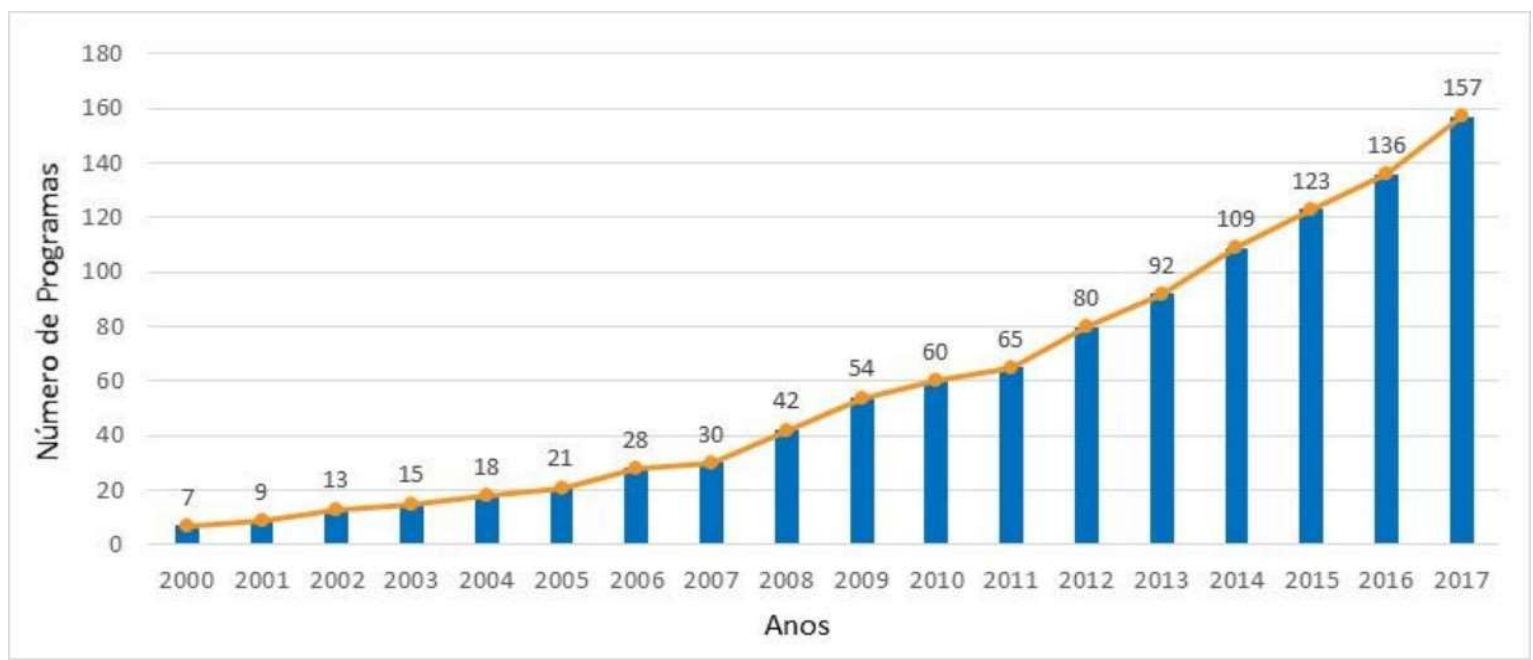

Fonte: CAPES, 2017

Um "personagem" mais recente na história da área é o mestrado profissional, que é fundado em 2001 na UFRN. Atualmente o número de programas dessa nova modalidade, que visa a formação profissional e aplicação mais pragmática ao ensino, já é maior do que o número de programas de mestradoacadêmico.

- $\quad$ Aumento do número dos eventos e publicações específicas: a criação dos simpósios e outros eventos específicos para ensino de ciências aumentou em número e estabilidade na frequência de ocorrências. O pioneiro SNEF, por exemplo, acontece bienalmente, variando a localização pelos estados do Brasil. Além do SNEF, EDEQ e ENEQ, surgiram também o EPEB (Encontro Perspectivas do Ensino de Biologia, em 1982), o SSBEC (Simpósio Sul Brasileiro de Ensino de Ciências, em 1983), o ENPEC (Encontro Nacional de Pesquisa em Ensino de Ciências, em 1997) e outros (FERES e NARDI, 2014). De modo semelhante, também há um aumento da publicação em periódicos. Além da revista Cultus, criada pela IBECC, surgem a Revista Brasileira do Ensino de Física, o Caderno Catarinense do Ensino de Física, Ciência \& Educação, Experiências em Ensino de Ciências, Alexandria e outras. O aumento do número dos programas, dos simpósios e das publicações, que em outrora constituiu um fator importante para a institucionalização da área, passa a compor um espaço para o compartilhamento de ideias em comum e fortalecimento da área. 
- Reconhecimento do Ensino de Ciências como área de pesquisa institucionalizada: a área de ensino de ciências, conforme afirma Nardi (2005), encontrou obstáculos nos primeiros passos de sua institucionalização. Um desses principais obstáculos é referente ao reconhecimento dos pesquisadores das áreas de "ciências duras", que tendiam a diminuir ou questionar a qualidade da "pesquisa" daqueles que se envolviam com a nova área, principalmente pela alocação dos novos programas nos Institutos de Física. O reconhecimento do Ensino de Ciências como área de pesquisa se dá após ações de pressão e encontros, tais como o I EPEF (NARDI, 2005; DIAS, 2008), que focaliza questões específicas de pesquisa em ensino de física (de natureza diferente do SNEF, por exemplo). Além disso, a nível "oficial", algumas medidas valorizavam a área: uma delas é o edital PADCT/CAPES, na forma de financiamento para a formação acadêmica no exterior, incluindo os pesquisadores em Ensino de Ciências. Outra delas é, no ano de 2000, a criação da Área de Ensino de Ciências e Matemática, que posteriormente foi incorporada à Área de Ensino (Área 46 da CAPES).

- $\quad$ Ampliação dos enfoques de pesquisa, incluindo referenciais teóricos e metodologias: esse ponto é bastante relevante na definição das principais características da área. Os primeiros referenciais teóricos, baseados no modelo da mudança conceitual e concepções alternativas, dão espaço a novas abordagens, mediante insuficiência para a resolução dos problemas propostos. Partindo de uma crença inicial de que esses referenciais teóricos seriam suficientes para resolver todos os problemas, os novos referenciais assumem natureza diversa, recorrendo a abordagens linguística, sociológica, filosófica, etc. Consequentemente, há uma "dispersão" da publicação dos participantes da área, que, além de comunicar seus resultados aos pares da área de ensino, também interagiram com pesquisadores de outras áreas.

O momento atual da área, em suma, é caracterizado por tal pluralidade de abordagens, em formato interdisciplinar. Depois de um longo período percorrido, hoje pode-se dizer que há, de fato, uma área de ensino de ciências, que realiza pesquisa específica. Nesse contexto, há reconhecimento de vários dos grupos responsáveis pela prática científica no Brasil, inclusive de órgãos oficiais de fomento e de pesquisadores pertencentes a outras áreas.

Dada a especificidade desse trabalho, uma síntese importante a se fazer é sobre a presença dos trabalhos que integram a história da ciência ao ensino de 
ciências: essa interface não é recente, sendo presente na formulação dos projetos de ensino (especialmente projeto Harvard), nos eventos científicos e na publicação específica, que inclui também a produção vinculada aos programas de pós- graduação da área de Ensino de Ciências.

Assim, em todo esse processo de estabelecimento da área, a linha de trabalho em história da ciência e ensino marca presença constante. Nos primeiros momentos, marcados pelas pesquisas do tipo P\&D e referenciais teóricos como a mudança conceitual e aprendizagem significativa, a história da ciência fornecia analogias para a compreensão dos processos de construção de conhecimento.

Optamos assim, pela análise das fontes de dados históricos utilizadas na produção do PIEC, um dos mais longevos programas na área, buscando fornecer subsídios para melhor entendimento de como esta interface entre História da Ciência e Ensino de Ciências tem sido construída. Para tanto, iremos no próximo capítulo explorar alguns pontos que nos parecem relevantes nessa interface, começando pela discussão de alguns elementos da historiografia da ciência. 


\section{PROBLEMAS HISTORIOGRÁFICOS}

Nesse capítulo vamos nos debruçar sobre algumas questões e problemas que a historiografia da ciência vem enfrentando ao longo do tempo. Nosso propósito é construir um conjunto de reflexões que poderão ser úteis na análise de nossos dados.

\subsection{Relativismo e dogmatismo: mudanças na historiografia da ciência}

Essa questão, posta propositalmente como uma dicotomia, como uma oposição, tem sido alvo de grandes discussões, em especial no campo da filosofia, envolvendo as sub áreas da ética, epistemologia, dentre outras. É uma temática importante também no campo da História da Ciência, principalmente por envolver aspectos relacionados ao seu objeto de estudo e sua relação com a epistemologia envolvendo a ciência. Optamos, então, por trazer essa discussão como um modo de, posteriormente, entender algumas abordagens presentes nas teses e dissertações analisadas e também para ressaltar que critérios diferentes têm sido mobilizados para justificar os estudos sobre a ciência.

Interpretamos o relativismo como a atribuição de um sentido convencional às afirmações que já possuíram conotação absoluta, tendo seu sentido atribuído ao contexto. Essa definição encontra ressonância em um artigo da Stanford Encyclopedia of Philosophy, escrito por Baghramian (2015):

O relativismo, grosso modo, é a visão de que a verdade e a falsidade, o certo e errado, padrões de raciocínio e procedimentos de justificação são produtos de diferentes convenções e estruturas de avaliação e que sua autoridade está confinada ao contexto que lhes dá origem (BAGHRAMIAN, 2015, p. 1, tradução nossa).

Essa temática se faz relevante nos estudos teóricos sobre a Ciência porque uma característica muito importante do trabalho de lidar com diversos tipos de conhecimento é a inevitabilidade do contato com tradições diferentes (BURKE, 2012). O trabalho com história da ciência, em particular, muitas vezes lida com conceitos já não utilizados mais pela comunidade científica atual, além de lidar com concepções diferentes de atividade científica que podem diferir da prática da época em que se localiza o historiador. Exemplos variados revelam que grupos diversos, mesmo no 
interior da ciência, desenvolvem formas distintas de interpretar o mundo e de descrever fenômenos naturais.

Diante desse quadro, é possível traçar ao menos dois caminhos distintos emrelação às múltiplas formas de conceber a história do conhecimento humano.

Uma delas, mais dogmática, é a da adoção de um ponto de vista considerado correto e que possa servir de critério para avaliação do conhecimento científico do passado. A outra, mais próxima ao relativismo, é a do entendimento da igualdade entre as diversas tradições, como se fossem equivalentes. Certamente há também uma multiplicidade enorme de abordagens intermediárias entre esses dois extremos.

No caso da História da Ciência, em especial por recorrer à Filosofia da Ciência para "reconhecer" as manifestações da Ciência ao longo da história, tomar um posicionamento nesse debate se faz especialmente importante. $O$ historiador, ao propor uma interpretação vinculada a qualquer um dos pontos de vista, inevitavelmente revela aspectos relevantes de sua concepção do que é a Ciência e de seu valor no entendimento dos fenômenos de seu escopo.

Uma delas, bastante conhecida, é o valor atribuído à Ciência em relação aos outros tipos de conhecimento (como misticismos em geral, alquimia, astrologia, etc.). Tal questão pode ser abordada tanto de uma forma extremamente dogmática quando de uma forma completamente relativista, havendo confusões e malefícios para ambos os lados.

Outra delas é em relação ao papel dos fatores externos que influenciam na atividade científica. Uma posição extremamente dogmática interpreta a ciência como um empreendimento livre dos fatores sociais, enquanto outra abordagem atribui à ciência um papel puramente determinado pelos fatores externos (como contextos políticos, econômicos, religiosos, etc.)

Antes de prosseguir com exemplo mais claros sobre esses posicionamentos, cabe esclarecer a falta de consenso em relação a essa questão. É fato que a historiografia da ciência, tal como a própria filosofia da ciência, sofreu mudanças ao longo do tempo, com uma tendência de relativizar algumas concepções extremamente rígidas que hoje são tidas como ingênuas pelos historiadores e filósofos. Junto com tal relativização permaneceram também os críticos dessas abordagens, fazendo render um debate importante.

De modo geral, por motivos que serão explicitados, a historiografia da ciência ao longo de sua trajetória tendeu a uma maior relativização, no âmbito do escopo 
do seu objeto de estudo e também em algumas questões epistemológicas, como a questão dos critérios de avaliação do conhecimento científico e da demarcação do que é essa atividade.

Um autor que consideramos importante nessa discussão é Thomas Kuhn (1922-1996). Ele é o escritor de um livro bastante conhecido por interessados em história e filosofia da ciência em geral, A Estrutura das Revoluções Científicas ${ }^{4}$. A nosso ver, é justo considerar suas concepções numa discussão sobre relativismo, principalmente, porque ele é um marco importante para a historiografia da ciência. Videira (2007), por exemplo, diz:

A "antiguidade" da história da ciência parece ter lhe causado um problema sério, uma vez que ela não possui uma definição única. $A$ ausência de um consenso a respeito de como definir a história da ciência tornou-se evidente, parece-me, a partir da década de 1960, com as reações, fortemente críticas, à famosa obra de Thomas Kuhn, A estrutura das revoluções científicas. (VIDEIRA, 2007, p. 112)

Fato é que a ciência, para Kuhn, está sempre em mudança, e é sempre incompleta. A ciência, para Kuhn, sempre encontra momentos de crise, em que o paradigma vigente se mostra insuficiente para resolver alguns "quebra-cabeças". A substituição de um paradigma traz consigo, eventualmente, novos instrumentos, novas metodologias e novas formas de interpretar os eventos da natureza.

Dessa forma, Kuhn apresenta elementos, em sua concepção de ciência, que podem ser considerados, em certo grau, relativistas. lan Hacking afirma que, embora Kuhn rejeite "uma explicação completa, objetiva e verdadeira da natureza" (HACKING, 2017 , p. 44), ele "leva a sério" (ibid) a verdade. A questão é que, mesmo que Kuhn tenha rejeitado o rótulo de relativista (ASSIS, 2014), ele influenciou muitos outros autores que têm uma tendência considerada relativista (principalmente em relação aos fatores sociais), como o grupo dos pesquisadores pertencentes ao Science Studies (VIDEIRA, 2006).

Portanto, é fato que a História da Ciência tem mudado ao longo do tempo e adotado tendências sociológicas mais relativistas. Durante a realização dessa pesquisa pudemos perceber alguns pontos relevantes de mudança na percepção

${ }^{4}$ KUHN, Thomas S. A Estrutura das Revoluções Científicas. 13 ed. São Paulo: Pesrpectiva, 2017. 
sobre a história da ciência.

Thomas Kuhn argumenta que, no século XX, a história da ciência sofreu algumas mudanças importantes, dentre as quais está uma mudança de concepção em relação ao próprio objeto de estudo: a ciência deixaria de ser vista como um "acúmulo cronológico de resultados positivos numa especialidade técnica definida em retrospecto" (KUHN, 1968, p. 130). Para ele, alguns fatores envolvidos nessa mudança de concepção são:

1. A influência da História da Filosofia, que passa a adotar uma postura de maior ceticismo em relação à distinção feita entre os conhecimentos considerados corretos e errados ao longo da história;

2 A impossibilidade de entender algumas descobertas feitas (por Pierre Duhem) sobre a ciência medieval quando feitas de forma não-contextual. Esse fator também abriu portas para novas temáticas, principalmente por associar o papel do conhecimento medieval à ciência posterior;

3. A problemática envolvida na escrita de uma História Geral da Ciência, assim como a impossibilidade de aplicar às ciências do passado as mesmas divisões das ciências contemporâneas.

Todos esses fatores de mudança indicados por Kuhn são indícios da necessidade de uma relativização maior para uma melhor compreensão do passado da ciência. Dessa forma, de meados do século XX até atualmente, a História da Ciência passou por um processo de incorporar, por exemplo, fatores sociais como elementos cruciais para o desenvolvimento de um determinado corpo de conhecimentos de uma determinada época. Nesse contexto surgiram alguns autores, como David Bloor e os autores da tradição dos Science Studies, como Bruno Latour, Peter Galison, Steven Shapin, dentre outros.

A questão do relativismo tem sido alvo de discussões importantes entre autores de história da ciência, principalmente porque assumir que há uma suposta igualdade entre as diversas tradições científicas recai no risco de confundir as barreiras do conhecimento considerado válido ou não. Quando se trata do conhecimento científico, uma posição relativista extrema é especialmente prejudicial justamente por tender a extinguir o possível valor de verdade presente nas proposições científicas. 


\subsection{Internalismo e externalismo: a abordagem temática}

Outro ponto de importância, ao se estudar o conhecimento histórico sobre a ciência, entender que as mudanças exploradas no item anterior, em especial aquelas que levaram ao surgimento dos Science Studies, também envolvem o modo como se entende as mudanças no corpo de conhecimento científico.

Estabelecemos, pois, aqui, uma discussão que consideramos central para entender parte dos trabalhos que analisamos do ponto de vista da construção de um relato historiográfico. Embora a discussão sobre relativismo e dogmatismo na história da ciência seja extremamente relevante, é por meio da discussão entre internalismo e externalismo que gostaríamos de entender se há alguma relação entre a abordagem temática e a utilização de determinados tipos de fontes.

Particularmente gostaríamos de ressaltar que esse nos é um tópico muito caro. Apesar de essa discussão ser, por muitas vezes, considerada obsoleta quando posta como uma dicotomia, ela mesmo foi ressignificada e continua sendo de extrema importância para o entendimento da historiografia das ciências e do próprio papel de ciência na sociedade.

A área de ensino de ciências, por sua vez, ainda demonstra preocupação com essas abordagens, e autores se debruçam por entender as implicações da escolha por uma delas.

Apresentaremos uma visão mais recente desse debate e que apresenta uma visão menos dicotômica, fruto da escola dos Science Studies e, portanto, apresentando uma visão de ciência próxima ao externalismo. Antes de apresentar aspectos desse debate, gostaríamos de tecer alguns comentários sobre a definição geral dessas escolas.

Antes de conceituar cada uma dessas vertentes, buscamos localizar esse debate numa questão mais ampla, a qual Burke (2015, p. 154) exemplifica de modo interessante. Segundo ele, "a grande pergunta é se o formato de uma certa sociedade determina ou simplesmente influencia os conhecimentos a serem encontrados dentro dela".

Além do questionamento sobre a influência da sociedade no conhecimento, cabe também o entendimento contextual das diversas concepções sobre a ciência ao longo da história. Para entendermos mais dessa dicotomia, recorremos ao estudo do 
pensamento de Círculo de Viena e debates ao redor dessa escola. Após isso, apresentamos a definição mais ampla de internalismo e externalismo e, por último, a concepção de Latour.

Rudolf Carnap, um importante membro do Círculo de Viena, sustentava a ideia de que os estudos científicos deveriam se voltar, todos, à investigação do "contexto de justificativa”. Segundo Silva (2009, p.62), os filósofos do Círculo de Viena se preocupavam exclusivamente sobre "a forma como um cientista leva sua descoberta ao público a fim de angariar reconhecimento e legitimidade para sua pesquisa”.

Pode-se imaginar, então, que um grupo com tais concepções seria crítica de outras formas de narrativa do conhecimento científico, em especial àquelas preocupadas com fatores "extracientíficos", ou os contextos de descoberta. Essa nova tendência, surgida na década de 1920, é marcada pela sociologia do conhecimento de Mannheim.

De modo geral, a novidade trazida por Mannheim aos estudos científicos é a de considerar a interligação da obtenção de conhecimento ao contexto mais amplo no qual ele está localizado. Além disso, Mannheim não se preocupou "com a demarcação entre o científico e o não científico" e nem "com 'a assepsia lógica e empírica' das proposições a respeito do conhecimento empreendida pelos vienenses" (SILVA, 2009, p. 61).

Olhar para essas duas escolas permite entender a problemática envolvida na análise mais interna da ciência, com suas características bem demarcadas e imunes ao contexto; e na análise mais externa, onde o contexto é de extrema importância para entender o conhecimento.

Dessa forma, à abordagem que interpreta que o formato da sociedade determina o conhecimento, damos o nome de externalismo. A historiografia externa, então, incorpora termos relacionados ao amplo contexto em que os cientistas vivem. o externalismo "admite que as circunstâncias sociais, econômicas, políticas e culturais afetariam a busca do conhecimento científico propriamente dito" (MAGALHÃES e SALATEO, 2015, p.17).

A concepção internalista, por sua vez, entende que há uma divisão clara entre o contexto e a ciência. A ciência operaria através, unicamente, de sua lógica interna, e a "dimensão social da ciência surgiria então e no máximo apenas por ocasião da disseminação do conhecimento científico" (ibid). 
Essa dicotomia tem lugar nas críticas que o Círculo de Viena e outros estudiosos fazem à abordagem de Mannheim, em especial quando Reichenbach propõe uma separação entre os contextos de justificativa e descoberta. Pode-se dizer que aquilo que Carnap propõe é análogo ao que chamamos de internalismo. A problemática surge, pois, "os 'internalistas' acham a abordagem externa insensível, enquanto os 'externalistas' consideram a abordagem interna restrita demais" (BURKE, 2015, p. 154). "Insensível", pois, considera que a lógica científica não é imune ao contexto e "restrita" porque a abordagem internalista justamente não considera o contexto em torno do núcleo científico.

Uma forma de compreender esse debate é por meio das concepções do grupo dos Science Studies. De modo resumido, tal concepção visa uma apresentação com categorias mais flexíveis e que se definem através dos próprios acontecimentos históricos estudados.

A abordagem do grupo dos Science Studies é, muitas vezes, considerada extremamente sociológica e relativista. Dessa crítica surgiu a necessidade de esclarecer a natureza dessa crítica (posta em termos de dogmatismo e relativismo no item anterior) e, agora, gostaríamos de expor uma nova concepção de internalismo e externalismo pautada nas ideias desse novo grupo. Para tanto, nos pautamos nas ideias de Bruno Latour.

A ideia básica defendida por esse autor é a rejeição a priori da narrativa historiográfica separada em "interna" ou "externa". Latour defende que o objetivo dos Science Studies não é a construção social da realidade científica ou da determinação dos conceitos científicos pelos fatores sociais, mas sim do entendimento de como a relação da ciência com a sociedade se constrói pelos próprios autores.

Dentro dessa concepção de historiografia, é muito interessante compreender como se dá a interação dos cientistas com a sociedade ao seu redor. Latour argumenta, então, que

Em suma, o projeto dos estudos científicos, contrariamente ao que os guerreiros da ciência queriam induzir todos a crer, não é estabelecer a priori que existe "alguma conexão" entre ciência e sociedade, pois a existência dessa conexão depende daquilo que os atores fizeram ou deixaram de fazer para estabelece-la. Os estudos científicos apenas fornecem os meios de traçar essa conexão quando ela existe. Em vez de cortar o nó Górdio - de um lado a ciência pura, de outro, política 
pura -, eles procuram acompanhar os gestos daqueles que o apertam ainda mais. (LATOUR, 2017, p. 104).

Dessa forma, o modo como se interpreta o debate internalismo vs. externalismo é alterado. De certa forma, o relacionamento da ciência com a sociedade passa de uma concepção pré-estabelecida a uma concepção que se constrói perseguindo os passos do autor e, portanto, muito mais fluida e híbrida. Os limites do que é o internalismo e o externalismo se confundem em prol de uma concepção mais ampla do período estudado.

Entretanto, persiste a dúvida em relação ao mapeamento dessas concepções ao longo de um determinado período histórico. Posto em outros termos, é um pouco mais complicado de se entender os indicadores dessas concepções quando se adota o ponto de vista dos Science Studies. Latour, ao refletir sobre isso, argumenta que há uma espécie de mistura nos discursos presentes no "interior" da ciência e em seu "exterior". Na verdade, esse discurso misto se constitui parte da própria atividade científica e é obtido perseguindo o discurso dos atores, em cadeias de translação que são construídas puramente na atividade, e não categorizadas a priori.

Para esclarecer a complexidade das ideias de Bruno Latour a respeito dasdiferentes concepções internalistas e externalistas, contrapomos duas diferentes formas de se entender esse debate.

Figura 1 - Dois modelos para o debate internalismo e externalismo
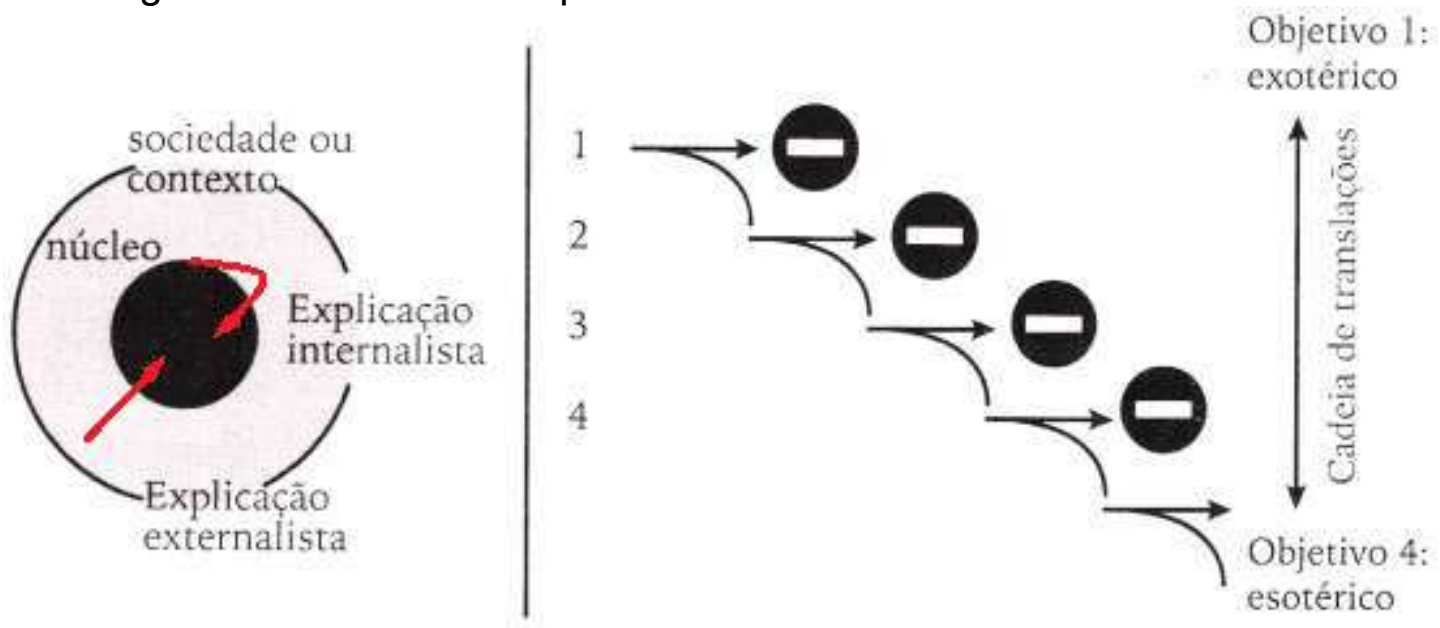

MODELO 1

MODELO 2

Fonte: adaptado de LATOUR, 2017 
$\mathrm{Na}$ figura à esquerda, que corresponde ao modo mais tradicional de se entender "internalismo" e "externalismo", é possível perceber que as abordagens são diametralmente opostas. O núcleo científico aparece como uma categoria a parte dentro do próprio contexto e as diferentes abordagens partem de lugares diferentes e atingem diferentes áreas da ciência em questão, perpassando pelos fatores sociais.

No segundo modelo, o qual é defendido por Latour, a diferença não está em categorias pré estabelecidas, mas sim nos discursos dos atores que se modificam, negociando com as teorias científicas e os diversos atores da sociedade. A própria diferença entre as abordagens internalista e externalista muda conforme os cientistas interagem mais ou menos com a sociedade, e, claro, isso se revela através das fontes de pesquisa.

Decidimos, pois, adotar tal visão desse debate. Não desejamos, neste trabalho, destrinchar cada abordagem temática e fazer as concepções dos autores encaixar nesse modelo. Desejamos, antes de tudo, compreender que há um dinamismo na própria definição de internalismo e externalismo. A adoção de um modelo como esse proposto por Latour nos permite entender essas diferenças e o pluralismo nas diferentes abordagens que os autores carregam.

Referente à relação entre as fontes históricas e a abordagem, consideramos que uma abordagem mais dinâmica dos conceitos de internalismo e externalismo seria mais adequada para entendermos também o processo de procura e seleção de fontes. Em nossa opinião, a adoção de uma concepção mais dinâmica sobre esse debate pode ampliar as formas de entendimento dos discursos dos atores envolvidos.

\subsection{Fontes na historiografia da ciência: dimensões e definições}

Seguindo uma distinção proposta por Kragh (1987), optamos por distinguir os termos relíquia e fontes. Ao primeiro, atribui-se o significado de algo que foi construído em determinadas condições no passado com intencionalidades próprias de alguma época. Esses materiais correspondem às várias produções humanas, das quais muitas são perdidas e destruídas e outras que são mantidas e preservadas pelas forças de interesses diversos que agem sobre tal material (LE GOFF, 1994).

O termo "fonte", por sua vez, surge da interpretação que um historiador faz de uma determinada relíquia $(\mathrm{KRAGH}, 1987)$. Dessa forma, há uma tensão entre 
diferentes períodos, carregando diferentes contextos de diferentes épocas. As fontes constituem, então, o principal material de investigação do historiador. Com base nas fontes é possível fazer afirmações e conclusões sobre o passado.

Para organizar esse tópico, optamos por dividir a questão das fontes em três dimensões interdependentes, que nos ajuda na organização dos tópicos. Essas dimensões são uma construção nossa baseada na leitura dos textos citados, além de outros trabalhos de narrativa histórica.

1) Dimensão epistemológica - lidar com fontes, em especial quando se lida com fontes primárias, envolve lidar com um material produzido em condições específicas do passado. Quando se lida com a história da ciência, por exemplo, o discurso se mantém determinado pelas condições de cada época, como diferentes visões de mundos, terminologias variadas e outras questões particulares de cada ciência. Além disso, como ressaltado nos textos anteriores, a mobilização de fontes se dá com bases historiográficas diversas, envolvendo as questões de demarcação, o valor epistemológico da ciência, dentre outras questões. A dimensão epistemológica se refere à existência de diferentes escolas e abordagens historiográficas que interferem no modo como se interpreta as fontes utilizadas.

2) Dimensão histórica - Jacques Le Goff (1994) mostra que, no início da idade média, era comum haver falsificação de documentos, como diplomas e cartas. Caso essas falsificações não fossem descobertas, haveria a possibilidade de utilizálas como fontes fidedignas. A questão principal é que os variados tipos de discurso são condicionados historicamente, o que determina várias de suas características, impactando seu uso como fontes. Um outro exemplo interessante de como a dimensão histórica (no sentido de "fatos históricos") é importante para se analisar o uso de fontes é a criação de arquivos para armazenar e preservar documentos, o que auxilia na disponibilidade futura de fontes (BURKE, 2012). A dimensão histórica se refere, portanto, ao condicionamento histórico do discurso e como suas características são mutáveis e alocadas em esferas específicas de atividade. Utilizaremos os gêneros discursivos de Bakhtin para um entendimento mais detalhado de como os materiais históricos são construídos, levando em conta sua historicidade.

3) Dimensão prática - outros problemas interessantes na consulta às fontes aparecem pela questão da própria disponibilidade dessas fontes, na afinidade com o idioma de produção delas e, mais recentemente, no importante movimento de 
digitalização e armazenamento dos variados materiais produzidos pela humanidade. Nessa última dimensão, discutimos algumas dessas questão concernentes ao acesso da fonte, como a localização dos materiais e sua língua original de escrita.

\subsubsection{Dimensão epistemológica}

Há uma frase do historiador Fustel de Coulanges (1830 - 1889) que é bastante profunda e significativa do ponto de vista do que significa a existência, a seleção e utilização de fontes pelo historiador.

Onde faltam os monumentos escritos, deve a história demandar às línguas mortas os seus segredos [...] Deve escutar as fábulas, os mitos, os sonhos da imaginação [...] Onde o homem passou, onde deixou qualquer marca da sua vida e da sua inteligência, aí está a história. (COULANGES, 1901 apud LE GOFF, 1994, p. 88; grifos nossos).

A frase em grifo pode ter seu sentido transportado à história das variadas atividades humanas, na qual se inclui a ciência. Sendo essa uma atividade da racionalidade e da inteligência humana, é impossível, pois, que não deixe profundas marcas ao longo das sociedades ao longo do tempo.

Cabe ressaltar, entretanto, que, ao longo da história, o próprio significado da existência de vestígios e seu uso como fontes foi modificado pelas diversas concepções historiográficas. Fustel de Coulanges era um historiador positivista e o trecho citado carrega certas concepções dessa escola.

lan Hacking (2017) nos mostra que há seis características principais que orientam o positivismo como filosofia do conhecimento. Aqui, gostaríamos de ressaltar algumas delas, a saber: ênfase na verificação, pró-observação e antientidades teóricas.

Segundo Hacking, as "proposições significativas são aquelas cuja verdade ou falsidade podem ser determinadas de alguma forma" (p.107), sendo que a observação é a melhor forma de fundamentar nosso conhecimento não-matemático sobre o mundo. A terceira característica acima pode ser, de modo bastante resumido, entendida como uma restrição da realidade estritamente ao que é observado, rejeitando inferências puramente teóricas sobre o mundo.

É como se a concepção de Fustel pudesse ser interpretada, dentro da 
característica anti-teórica do positivismo, como o fato de a história só existir onde o ser humano passou, onde o ser humano deixou seus vestígios. A fonte, nesse caso, é a prova direta das atividades humanas e surge da inevitabilidade do surgimento desses vestígios, funcionando como uma revelação inequívoca dos fatos ocorridos no passado.

Apesar das críticas que podem ser dirigidas às concepções positivistas, esse é um exemplo de como a discussão sobre o uso de fontes é uma temática importante para a escrita da história e da história da ciência. Consideramos, então, que não se trata de produzir reveleções inequívocas, mas o trabalocom as fontes trata de interpretação de vários aspectos presentes nos materiais.

Uma questão muito importante, discutida por Kostas Gavroglu (2007), é que o historiador lida com muitas fontes, o que implica em muitas vozes que falam ao mesmo tempo e que às vezes são conflitantes entre si. A dimensão epistemológica do uso das fontes surge da tensão entre um quadro de expectativas prévias próprias do historiador e o que as fontes dizem:

O problema é se os historiadores imporão às vozes que digam aquilo que eles próprios querem ouvir ou se conseguirão dominar o choque fatal que se dá entre aquilo que as vozes dizem e aquilo que os historiadores querem ouvir. $E$ isto porque as vozes da história possuem uma particularidade singular: fazem-se ouvir apenas porque os historiadores, com os seus preconceitos e os seus propósitos, formaram um quadro básico de expectativas concretas a respeito do tipo de respostas que pretendem. (GAVROGLU, 2007, p. 113)

Dessa forma, a interpretação das fontes se dá, necessariamente, dentro de um quadro teórico específico, que formula uma visão de ciência, da sua relação com a realidade e com a ciência, de seu valor epistemológico, etc.

\subsubsection{Dimensão histórica}

O discurso carrega consigo as especificidades das condições em seu entorno. A dimensão histórica das fontes é a dimensão material do discurso, tal como composto em condições específicas e formado por características que nos ensinam sobre tal contexto. Recorremos, aqui, aos gêneros discursivos de Bakhtin para explicar a dinâmica da composição desses gêneros.

Para compreender essa discussão, é importante ter em mente que a linguagem só se constitui através do diálogo. Consideramos que esse referencial é importante 
porque a ciência também é uma atividade dialógica e, portanto, envolve o uso da linguagem pelos seu atores.

\subsubsection{Bakhtin e a concepção dialógica da linguagem}

A discussão sobre os gêneros discursivos nesse trabalho tem esse propósito de valorização de variadas formas discursivas. No contexto científico, conhecemos bem essas formas: artigos científicos, livros e manuais, etc.

Tal discussão também sinaliza o entendimento da importância do diálogo, do reconhecimento das várias esferas de uso da palavra e da necessidade de se aproximar do repertório de gêneros de discurso utilizado pela ciência e pelos historiadores para se comunicarem.

A riqueza e a diversidade dos gêneros do discurso são infinitas porque são inesgotáveis as possibilidades da multifacetada atividade humana e porque em cada campo dessa atividade vem sedo elaborado todo um repertório de gêneros do discurso, que cresce e se diferencia à medida que tal campo se desenvolve e ganha complexidade. (BAKHTIN, 2017, p. 12)

Dessa forma, conforme aponta Bakhtin (2017), se encaixam na análise discursiva situações aparentemente simples (como, por exemplo, o cumprimento cotidiano) até as composições mais complexas e elaboradas (como, por exemplo, uma obra filosófica extensa). Além disso, as próprias atividades se modificam e se tornam mais complexas, incorporando variados tipos de gêneros em seu interior. Em suma, os gêneros, vinculados às esferas de atividade, possuem historicidade. A ciência como uma atividade dinâmica possui uma infinidade de discursos que se modificam com o tempo e, também, possui certa historicidade.

A linguagem para Bakhtin, então, é necessariamente histórica, social e também cultural. Ela sempre é considerada a partir desses três pontos de vista (BRAIT e MELO, 2005). Daí a valorização que Bakhtin emprega à comunicação entre os sujeitos e a composição de seus discursos sob as diversas condições no entorno deles.

Bakhtin, em suma, propõe um modo de pensar o diálogo, que vai desde as saudações cotidianas até a comunicação em campos mais desenvolvidos, como dentro da ciência.

Ainda que não tenha falado em termos "bakhtinianos", Knorr-Cetina (1999) exemplifica bem a importância da comunicação para o campo científico. Essa forma 
de pensar valoriza, especialmente, a forma social da ciência, que envolve o contato entre vários cientistas.

[...] a comunicação é dita ser intrínseca à ciência pelo facto de a ciência moderna ser um empreendimento colectivo que depende de os resultados obtidos por cientistas individuais serem retomados por outros cientistas que se fundam neles e os desenvolvem. A ciência projecta-se a si mesma no futuro através da comunicação. Uma ciência privada é tão impensável como uma linguagem privada. (KNORR-CETINA, 1999, p. 378, grifos nossos)

Os estudos de Bakhtin são bastante amplos. Nessa pesquisa exploramos apenas alguns aspectos. Primeiramente consideramos os conceitos de enunciado, comunicação e gêneros discursivos.

\subsubsection{Enunciado e comunicação}

Para Bakhtin (2017), a comunicação humana se dá por meio de enunciados concretos e únicos. Para entender o que é um enunciado, podemos imaginar uma situação comunicativa qualquer, como uma saudação/cumprimento seguido de uma resposta. Cada uma das falas se constitui de um enunciado, e aí se dá um diálogo. Tal diálogo pode ser composto de perguntas e respostas, além de comentários diversos.

O enunciado pode ser composto de uma oração ou de um conjunto de orações. O enunciado pode ser composto até mesmo de uma única palavra. A extensão enunciativa, então, não se refere às unidades básicas da língua, mas sim à alternância. Segundo Bakhtin (2017, p. 29), "os limites de cada enunciado concreto como unidade da comunicação discursiva são definidos pela alternância dos sujeitos do discurso, ou seja, pela alternância dos falantes".

A questão dos sujeitos do discurso em Bakhtin é um problema importante, uma vez que toda comunicação é direcionada ao outro, que assume um papel ativo. Dessa forma, Bakhtin construiu uma crítica ao modelo comunicativo baseado no fluxo do discurso do "falante" para um receptor (o "ouvinte"), no qual o ouvinte, ainda que busque entender o discurso, teria papel passivo na comunicação.

Para Bakhtin, a posição do "ouvinte" na comunicação é tão ativa quanto a do falante: ao ouvir, ele se dispõe a entender, a concordar, responder, discordar, completar. O ouvinte assume também uma posição ativa responsiva. Em variadas 
intensidades de "ativismo", o ouvinte sempre é ativo na comunicação.

No caso do diálogo cotidiano, os sujeitos claramente são ativos. Ao ouvir "olá", o segundo falante se dispõe a reagir. Essa reação, a partir do momento de entendimento do primeiro enunciado, pode ser variada: ele pode permanecer em silêncio, buscando lembrar quem é a pessoa que está lhe dirigindo a palavra; pode pronunciar um outro enunciado "olá": pode responder com um estranhamento e aguardar outra manifestação do primeiro sujeito. Seja qual for a "reação" desse segundo indivíduo, ela será uma posição responsiva ativa.

A posição ativa responsiva também está no falante na formulação do seu discurso. Bakhtin afirma que um falante também é "um respondente em maior ou menor grau". Certamente quem fala não é o primeiro a falar. Além disso, quem fala é influenciado por uma série de discursos anteriores e mantém, com eles, uma relação de concordância ou discordância, de dependência, de pressuposição da existência (Bakhtin, 2017). Em resumo, o enunciado assume várias formas e as atitudes responsivas também.

Essa situação é bastante conhecida no campo científico, uma vez que ideias são compartilhadas a todo o tempo. Sempre há alguém para concordar, discordar, discutir e reformular ideias científicas.

\subsubsection{Os gêneros discursivos de Bakhtin}

O estudo dos gêneros discursivos feito por Bakhtin representa um compromisso com a cultura de forma mais ampla através da ampliação dos domínios de entendimento das formas discursivas. Nesse contexto predomina a análise para além da mera classificação dos gêneros discursivos. Mantemos em mente os processos dialógicos que, para nós, representam fluxos de ideias e atitudes responsivas ativas perante o discurso do outro, formulandonovos discursos.

Assumindo o pressuposto proposto por Bakhtin na análise dos gêneros discursivos, as atividades humanas são interligadas ao uso da linguagem. Fiorin (2006) argumenta que essas atividades estão alocadas em esferas, que abrangem campos como o trabalho, a política e as relações de amizade. Para o pesquisador em historia da ciência, provavelmente a esfera de atividade mais relevante é a esfera científica.

Essas esferas de atividade formam um contexto para utilização de enunciados, 
no sentido em que não há uso da linguagem a não ser vinculado a tais esferas. Uma consequência importante disso é que, estando imersos em contextos de utilização, esses enunciados refletem algumas especificidades do campo: a finalidade e as condições específicas. Bakhtin também chama essas esferas de atividade de "campos de comunicação", evidenciando a ligação entre as atividades e o uso da linguagem.

Esses enunciados, alocados nessas esferas de atividade, possuem três características específicas. Os enunciados refletem as especificidades de um campo. Isso se dá por meio de três características enunciativas que são manifestações individuais que refletem as especificidades de um campo por meio do conteúdo temático, do estilo e da construção composicional

É importante notar que, apesar da individualidade dos enunciados, eles são agrupados entre si em determinados tipos relativamente estáveis, os quais denominamos "gêneros do discurso".

Segundo Fiorin (2006), o conteúdo temático se refere ao "domínio de sentido" de um dado gênero discursivo. Se trata de um agrupamento de conteúdos temáticos específicos, como, por exemplo, os artigos científicos que tratam de expor pesquisas científicas e seus resultados.

A construção composicional, por sua vez, se refere à forma organizacional do texto. Os diversos gêneros possuem modos de estrutura textual diferentes, como, por exemplo, o modo das cartas de estarem vinculadas a um local e um momento por meio da indicação direta do local do remetente (FIORIN, 2006).

A estilística do gênero discursivo corresponde à seleção dos meios discursivos: meios lexicais, fraseológicos ou gramaticais e que estão também associados ao gênero discursivo. A discussão de um determinado gênero - ou de formas típicas de enunciados - leva em consideração a individualidade do enunciado e, consequentemente, a individualidade do estilo.

As diferenças dos gêneros do discurso (com as diferentes finalidades e condições específicas) determinam quais daqueles são mais propícios à manifestação do estilo individual do falante (ou do escritor). Bakhtin argumenta que os gêneros ficcionais, em geral, permitem a manifestação do estilo individual do autor, enquanto os gêneros discursivos padronizados (o comando militar, o documento oficial, etc.) tendem a suprimir as manifestações do estilo individual. Apesar dessa tendência, entretanto, sempre há alguma manifestação, ainda que muito pequena, do estilo individual. 
Os nossos enunciados, então, se agrupam todos em algum gênero discursivo, os quais nos são ensinados sem que, necessariamente, tomemos ciência de sua existência:

Falamos apenas através de certos gêneros do discurso, isto é, todos os nossos enunciados têm formas relativamente estáveis e típicas de construção do conjunto. Dispostos de um rico repertório de gêneros de discurso orais (e escritos). Em termos práticos, nós o empregamos de forma segura e habilidosa, mas em termos teóricos podemos desconhecer inteiramente sua existência. [...] Esses gêneros do discurso nos são dados quase da mesma forma que nos é dada a língua materna, a qual dominamos livremente até começarmos o estudo teórico da gramática. (BAKHTIN, 2017, p. 38, grifos do autor)

Ao formular e pronunciar um enunciado, fazemos, na prática, uma opção por um gênero discursivo que se adapta à esfera de atividade na qual estamos imersos no momento da criação discursiva. Como exemplos de gêneros discursivos, citamos as diversas modalidades de escrita científica, nas quais se incluem o artigo científico, o manual didático, os relatórios de pesquisa, a divulgação científica, etc. Isso é um indício de que um mesmo campo de atividade pode abrigar um repertório variado de gêneros discursivos.

Tais gêneros discursivos agrupam tipos relativamente estáveis de enunciados. Segundo Fioran (2006), tal relativização se refere à historicidade contida no desenvolvimento dos gêneros discursivos: eles mudam, além de haver uma imprecisão na delimitação de gêneros semelhantes. A dinâmica de mudanças dos gêneros também se aplica na utilização deles nas esferas de atividade:

Não só cada gênero está em incessante alteração; também está em contínua mudança seu repertório, pois, à medida que as esferas de atividade se desenvolvem e ficam mais complexas, gêneros desaparecem ou aparecem, gêneros diferenciam-se, gêneros ganham um novo sentido. (FIORIN, 2006. p. 65)

Naturalmente, e isso é levado em consideração para a discussão do processo comunicativo através dos enunciados alocados em gêneros discursivos, há uma grande variedade e heterogeneidade de enunciados, refletindo a própria atividade humana que é diversificada e composta de variados gêneros de discurso.

A importância dessa concepção para a construção da dimensão histórica das fontes reside no fato de uma inserção que o pesquisador de História da Ciência faz no discurso, interagindo, numa concepção dialógica, com o autor do material que 
origina a fonte utilizada. Na prática, apreende-se muito do período histórico através do discurso. Isso ocorre, como visto, não só em termos do conteúdo específico, mas também em termos de estilo, composição física e condições específicas de produção.

Além disso, vimos que o discurso é sempre formulado em esferas de atividades. A análise de fontes leva isso em consideração, e muitos relatos historiográficos incluem textos produzidos em atividades diversas, como esfera pessoal, científica, acadêmica, religiosa, etc.

O fato do discurso ser pautado na linguagem também é relevante do ponto de vista da ciência ser uma atividade coletiva. Através da linguagem e, portanto, pautado em gêneros discursivos, o ator da história produz materiais relevantes para a atividade histórica, uma vez que todo seu discurso é influenciado pela cultura e contexto histórico de um período específico.

Os gêneros discursivos de Bakhtin se apresentam para essa pesquisa um referencial frutífero para análise de teses e dissertações que possuem interface com a história da ciência, tendo em vista que permite entender as fontes como produto de condições específicas (principalmente em relação à composição e ao conteúdo) .

\subsubsection{Dimensão prática}

Como temos defendido nesse capítulo, a consulta às fontes é um dos principais problemas presente no estudo da história. É necessário, antes de tudo, encontrar as fontes e separá-las para o uso.

Tomemos como exemplo o trabalho de pesquisa realizado por James Hunt (2015) para escrever o livro "Os Seguidores de Maxwell. Neste livro, ele trata dos principais cientistas que exploraram as teorias de Maxwell após seu falecimento. $O$ trabalho realizado por esse historiador utiliza diversos trabalhos de George Fitzgerald, Oliver Heaviside, Oliver Lodge e Heinrich Hertz para expor o desenvolvimento posterior das ideias de Maxwell entre o seu falecimento e 1873.

Ao construir a narrativa sobre os diversos cientistas que ele estuda, são utilizadas várias correspondências, manuscritos e diários de laboratórios, artigos científicos e alguns outros materiais. É interessante ver o cuidado que o autor demonstra com o manuseio das fontes, zelo este que se manifesta também na identificação das coleções e arquivos que abrigam os documentos exaustivamente estudados para a escrita do livro. Dentre vários outros arquivos, Hunt consulta três 
coleções voltadas apenas a armazenar e preservar a produção do cientista Oliver Lodge, por exemplo.

Essas coleções voltadas a armazenar a produção de Lodge são apenas algumas dentro de várias outras existentes pelo mundo que armazenam uma infinidade de materiais produzidos ao longo da história do conhecimento humano. Incontáveis metros cúbicos são dedicados a armazenar e preservar uma parte do que já foi anotado, escrito e publicado.

Burke explica que a criação e manutenção de arquivos e coleções é uma prática antiga, que data do século XVI:

Foi então que os governos [...] começaram a criar arquivos, contratar pessoas para mantê-los e formular regras que regulamentassem 0 acesso a eles. No século XIX, os arquivos aos poucos foram abertos ao público, "arquivista" tornou-se uma profissão e alguns arquivistas insistiam em preservar documentos que os governos desejavam destruir (BURKE, 2012, p. 82)

Os arquivos são uma forma de organização e preservação localizados fisicamente no espaço e no tempo. Representam uma das formas de perpetuar a materialidade de certos trabalhos produzidos.

Pela própria natureza desses arquivos - e aqui utilizamos o termo num sentido mais amplo, que inclui todos os locais físicos que armazenam trabalhos de interesse histórico - surgem grandes dificuldades na busca pelas fontes. Uma das mais evidente delas é o acesso ao arquivo, o que envolve a locomoção até a localização do arquivo.

Além disso, é necessário identificar quais são as coleções de interesse do pesquisador. Esse é o tipo de trabalho que se constrói a longo prazo e que exige experiência e uma boa rede de contatos, incluindo arquivistas e bibliotecários. Como explica o historiador Brian Ogilvie (2016), muitos arquivos ainda apresentam a dificuldade adicional de limitarem o tempo e a forma de consulta aos materiais ali armazenados. Muitas vezes, além do tempo limitado para a consulta, só é possível registrar o que é lido através do tradicional método de anotações em papel a próprio punho (OGILVIE, 2016).

Até alguns anos atrás a procura de fontes estava restrita àquelas presentes fisicamente nos arquivos. Entretanto, uma nova forma de acessar a história surgiu há algum tempo e impactou a prática da consulta de textos. Trata-se da digitalização 
de materiais presentes nos arquivos físicos.

A digitalização de documentos é uma atividade que mudou de modo bastante relevante a dinâmica de pesquisa em história da ciência, facilitando o acesso a documentos e criando novas formas de interação com o material a ser estudado. Entretanto, há questões relevantes presentes no ato da própria digitalização. Olgivie (2016) traz essas problemáticas em torno de quatro questões: o que é digitalizado? Quem pode acessar os arquivos? O que é perdido na digitalização? Quais são as possibilidades de um arquivo virtual?

No século XVI, a criação e manutenção de arquivos físicos representou, além de tudo que já foi dito, também um investimento financeiro. O mesmo acontece para a digitalização de arquivos. Tanto a iniciativa pública quanto a privada têm investido recursos para digitalizar e sistematizar a produção científica do passado. Uma coleção inteira, ainda que pequena, leva anos para ser digitalizada completamente. Nesse contexto, tudo que já foi digitalizado é fruto de uma seleção. O que se leva em consideração ao escolher o que deve ser digitalizado pode ser, eventualmente, a relevância histórica do material para os historiadores, para os arquivistas e bibliotecários e até mesmo para o público geral.

A princípio, o processo de digitalização implica em uma maior democratização do acesso ao conhecimento. E, de fato, há muitos trabalhos digitalizados e disponíveis gratuitamente. Olgivie (2016) ressalta, entretanto, que há alguns arquivos digitais que têm acesso controlado à informação, restringindo o acesso apenas aos mais interessados naqueles campos de estudo.

Outra questão muito importante na metodologia de trabalho com a história da ciência é, segundo Martins (2005), o fato de haver uma grande variedade de idiomas presentes nas diversas produções científicas ao longo da história. Os pesquisadores de história da ciência necessitam, portanto, dominar diferentes idiomas a fim de consultar fontes em seu idioma (em especial se tratando de fontes primárias). Na realidade, isso é um bom exemplo do condicionamento do discurso ao seu contexto de produção. A predominância da disponibilidade de materiais em certos idiomas não é arbitrária mas sim fruto de fatores diversos.

É possível exemplificar isso com alguns processos ocorridos na história, como, por exemplo, o deslocamento de cientistas para os Estados Unidos ao longo da Guerra Fria e o grande investimento feito nos campos científicos nesses país (HOBSBAWM, 1994). Esse é um dos indícios da maior probabilidade de se 
disponibilizar materiais na língua inglesa, em especial nas produções mais recentes do século $X X$.

Além da existência de materiais produzidos em diversas línguas modernas, a historiografia da ciência e do conhecimento humano em geral também exige, dependendo da temática de interesse do pesquisador, que este conheça, ao menos em alguma medida, línguas já extintas e fora de circulação.

$\mathrm{Na}$ história em geral, e particularmente na história da ciência, a tradução tem sido um processo de grande relevância e que ocorre de variadas maneiras. A existência de um material traduzido, em especial quando o autor não possui domínio da língua original, pode ser determinante na escolha da temática de estudo na história da ciência.

A tradução consiste, de modo simplificado, da reescrita de um discurso em uma outra língua, permitindo que uma pessoa sem conhecimento de sua língua original consulte determinado discurso. Porém, da mesma forma que facilita o acesso a fontes, a tradução também carrega também uma série de problemáticas.

Talvez a mais importante delas, e que é apontada por Martins (2005), é a fidedignidade apresentada na tradução de materiais. Essa autora recomenda que, na impossibilidade de se consultar a fonte em seu idioma original, deve-se fazer o uso do maior número de traduções possível, adotando uma postura comparativa entre elas.

Guerrini (2018) complementa a discussão sobre os problemas inerentes à tradução, argumentando que a tradução envolve escolhas de palavras e expressões para substituir aquelas anteriores no texto original. Eventualmente, imprecisões ocorrem nesse processo resultando em uma possibilidade de más interpretações e equívocos em relação às reais intencionalidades do autor.

Outro problema importante que envolve a leitura de textos traduzidos é a própria mudança que ocorre nos idiomas ao longo do tempo. Segundo Jean Aitchison (2004), esse processo de mudança é inevitável e representa que a linguagem segue o fluxo de mudanças às quais todas as atividades humanas e naturais estão sujeitas.

Naturalmente, há certo ressentimento e, eventualmente, certa resistência às alterações nas linguagens. Nessa transitividade, algumas palavras adquirem novos significados (Aitchison, 2004) e, inclusive, novas palavras são inventadas. Esses processos, principalmente na história da ciência, são de suma importância para a escrita dos relatos e, sobretudo, para a interpretação dos materiais.

Esse dinamismo na língua ocorre também para atender novas descovertas e 
proposições científicas. Guerrini (2018) argumenta, inclusive, que muitas vezes a ciência não só tem a necessidade de ampliar seus domínios de sentido, mas também chega ao caso de inventar novas palavras. A principal implicação para esses processos de mudanças em relação à interpretação de materiais (em especial as primárias) é uma necessidade maior de se entender cada idioma e cada terminologia em seu contexto de utilização, em especial através de fontes secundárias e de dicionários escritos na época.

\subsection{Síntese}

No primeiro capítulo apresentamos reflexões que foram frutos de pesquisa sobre a sobre a constituição da área de pesquisa em Ensino de Ciências no Brasil se alterarou ao longo do tempo. Percebemos que as interações com a história da ciência se alteraram acompanhando tendências de pesquisa e demandas educacionais específicas determinadas por fatores na área de ensino.

No segundo capítulo, exploramos algumas questões referentes à historiografia da ciência, em particular alguns problemas importantes que definem formas variadas de se escrever a história da ciência, como o valor de verdade das proposições científicas e a visão de ciência. Também apresentamos diversas dimensões do uso de fontes na atividade historiográfica.

Dentro desse contexto em que exploramos a dinâmica da área de ensino, da área de história da ciência e da própria interface entre essas duas áreas, cabe agora expor e aprofundar as questões de pesquisa suportadas por essas discussões e pela análise de dados.

No próximo capítulo nosso objetivo é situar nossa questão de pesquisa no contexto dado pelos capítulos anteriores, esclarecendo também como a pesquisa foi desenvolvida. 


\section{PERCURSO DE PESQUISA E METODOLOGIA}

Até aqui descrevemos as bases teóricas que utilizamos para entender melhor os dados que analisaremos e entender a pluralidade envolvida nos processos de construção dos relatos historiográficos contidos em teses e dissertações do PIEC, que envolve a seleção de fontes e os papéis que assumem em cada trabalho. Buscamos compreender fatores variados influentes na escrita historiográfica e relevantes para a compreensão da produção científica na linha de pesquisa em história da ciência do programa.

Nosso intuito agora é descrever mais profundamente nosso percurso metodológico de pesquisa. Cabe, portanto, retomar à pergunta de pesquisa já citada na introdução deste trabalho: "Quais são as fontes históricas e como elas têm sido utilizadas nas dissertações e teses produzidas no âmbito do PIEC?"

Uma vez esclarecida, teoricamente, a questão do significado das fontes em história da ciência, é necessário também esclarecer nossa escolha pela análise dos trabalhos contidos no Programa de Pós-Graduação Interunidades em Ensino de Ciências da Universidade de São Paulo (USP).

A escolha por analisar trabalhos contidos em programas de pós-graduação está na própria gênese desse tipo de produção. Consideramos que é uma das principais formas de conhecer as tendências de pesquisa na área de ensino. Tendo em vista o desejo de contribuir com a produção de conhecimento sobre as formas como a história da ciência pode chegar e auxiliar no ensino de ciências, escolhemos analisar teses e dissertações que vinculam a história da ciência ao ensino de ciências pelo potencial que possuem de impactar propostas didáticas para o ensino de ciências com uma perspectiva histórica.

O recorte em relação ao PIEC é fruto da aplicação de dois critérios que estabelecemos. O primeiro deles é referente à longevidade do programa e o segundo envolve a existência de uma linha de pesquisa na interface entre Ensino de Ciências e História da Ciência.

Com o critério de longevidade, visamos, principalmente, a obtenção de dados produzidos em épocas distintas. Com isso, há a possibilidade de enxergar se e como a produção do programa foi mudando e, principalmente, se possíveis alterações no acesso às fontes se manifesta. Um desses processos de mudança poderia ser 
decorrente da digitalização de arquivos e disponibilização ampla de arquivos digitais na rede, por exemplo. A escolha da longevidade se sustenta, pois, nessa possibilidade de identificar mudanças ao longo das décadas no grupo de teses e dissertações escolhido.

Já com o segundo critério, o objetivo é referente às implicações contidas na existência de uma linha de pesquisa em história da ciência. Entendemos que a existência de tal linha é resultante de uma preocupação específica em relação às questões envolvendo história da ciência e ensino e, portanto, relevante no contexto desse programa de pós-graduação. Nossa aposta principal para a formulação desse critério é que a existência de uma linha de pesquisa com essa temática implicaria em acúmulo desse tipo de produção, ou seja, a existência de um número amplo de teses e dissertações com a interface de nosso interesse.

Para a seleção do programa, levantamos algumas possibilidades, nos baseando nos eventos que marcaram o início da pesquisa na área de Ensino de Ciências. Desse modo, levantamos os dois programas mais antigos da área para verificar a existência de uma produção expressiva na linha de pesquisa de nosso interesse. Assim, identificamos os dois programas mais longevos da área: o programa de Ensino de Física da UFRGS e o PIEC da Universidade de São Paulo e optamos por investigar a produção do PIEC pela existência de uma linha de pesquisa específica em História e Filosofia da Ciência e pela expressiva produção desse Programa, quando comparado ao da UFRGS.

O PIEC, conforme pudemos apurar, produziu 600 teses de doutorado e dissertações de mestrado entre os anos de 1973 e o mês de agosto de 2017 nas variadas linhas de pesquisa que compõe o programa.

Dado o grande número de trabalhos, fizemos uma seleção com contínuos recortes, sendo que o primeiro, evidentemente, foi a seleção das produções envolvendo a interface da história da ciência com o ensino. Desse primeiro passo resultaram 76 trabalhos, equivalente a $10,8 \%$ da produção do PIEC no período. O passo seguinte foi o da seleção de trabalhos alocados na modalidade Ensino de Física, que resultou na permanência de 51 trabalhos. Dado o volume excessivo para o tipo de análise que pretendíamos fazer, optamos por um último recorte: a escolha de um trabalho para cada ano em que houvesse tal disponibilidade. Com isso, o conjunto final de trabalhos a serem analisados foi constituído por 24 produções. Esse número, apesar de representar apenas uma parcela dos trabalhos produzidos sob 
essa temática, é representativo de diversas épocas em que houve produção sobre história da ciência e ensino no PIEC.

Ressaltamos, nesse ponto, que há uma particularidade de se lidar com trabalhos acadêmicos. Foi necessário garantir que consultamos todas as teses e dissertações para selecionar o grupo apropriado para análise. Uma estratégia que utilizamos foi a utilização de diferentes listas, produzidas com base em diferentes métodos.

Em um primeiro momento, trabalhamos com o enfoque de garantir que incluímos nos nossos grupos todos os trabalhos possíveis. Entendemos que lidar com a catalogação desses trabalhos é análogo ao trabalho do historiador que lida com as fontes.

Num primeiro momento, consultamos a secretaria do PIEC, que é a responsável pela gestão das defesas das dissertações e teses no programa. A secretaria consegue, através do sistema de pós-graduação da Universidade de São Paulo (Janus), gerar uma lista com todas as teses e dissertações já defendidas no PIEC desde sua fundação.

Essa lista inclui também o nome dos autores, o ano e o(a) professor(a) que orientou o trabalho. A partir desse documento, chegamos ao primeiro número de 600 teses e dissertações e, a partir da leitura dos resumos e palavras-chave (que podem ser acessados através do sistema da biblioteca da Universidade), selecionamos as 76 teses e dissertações envolvendo história da ciência e ensino de ciências produzidas no programa.

Uma segunda lista, também bastante relevante, foi uma lista oferecida pela biblioteca do Instituto de Física. Essa lista incluiu alguns trabalhos de história da ciência, mas incluiu também vários outros trabalhos de outras faculdades da Universidade de São Paulo, uma vez que buscava por palavra-chave.

Uma terceira e última lista foi fornecida pelo PROFIS (Espaço de apoio, Pesquisa e Cooperação de Professores de Física) setor de apoio da licenciatura em Física. Essa lista possuía o diferencial de organizar as teses e dissertações pelas áreas de concentração: física, química e biologia. Através dessa lista obtemos o número de 51 teses e dissertações defendidas na modalidade Ensino de Física. 


\subsection{Dimensões de análise, categorias e índices}

Após definirmos o grupo de trabalhos que seriam analisados, criamos algumas dimensões de análise, construídas com base nas discussões teóricas feitas nos outros capítulos e enfocando alguns aspectos úteis para uma caracterização mais ampla dos trabalhos.

Na primeira dimensão dirigimos nosso olhar para as questões historiográficas buscando uma caracterização geral dos trabalhos nas abordagens internalista e externalista, uma vez que consideramos que essas questões também envolvem, ainda que em menor medida, tensões relacionadas ao relativismo (em especial o social).

A segunda dimensão de análise é justamente a que mais se aproxima de nosso principal objetivo de pesquisa. Se refere às fontes utilizadas e às questões pertinentes dentro dessa temática. Para essa dimensão de análise, construímos também subdimensões, categorias e indícios. Essa assimetria em relação às outras dimensões de análise é resultado do recorte escolhido em relação às fontes, o que nos levou a dirigir uma atenção especial a essa temática.

Por último, construímos mais uma dimensão de análise, desta vez referente à utilização das fontes no ensino de física. Com isso desejamos investigar eventuais proposições e contribuições em relação ao uso das fontes históricas como recurso didático para a sala de aula.

A tabela 1 abaixo apresenta essas dimensões e subdimensões de análises. Ressaltamos que foi fruto de um longo e frutífero processo de discussão em grupo. 
Tabela 1: Descritores e indicadores para análise dos dados

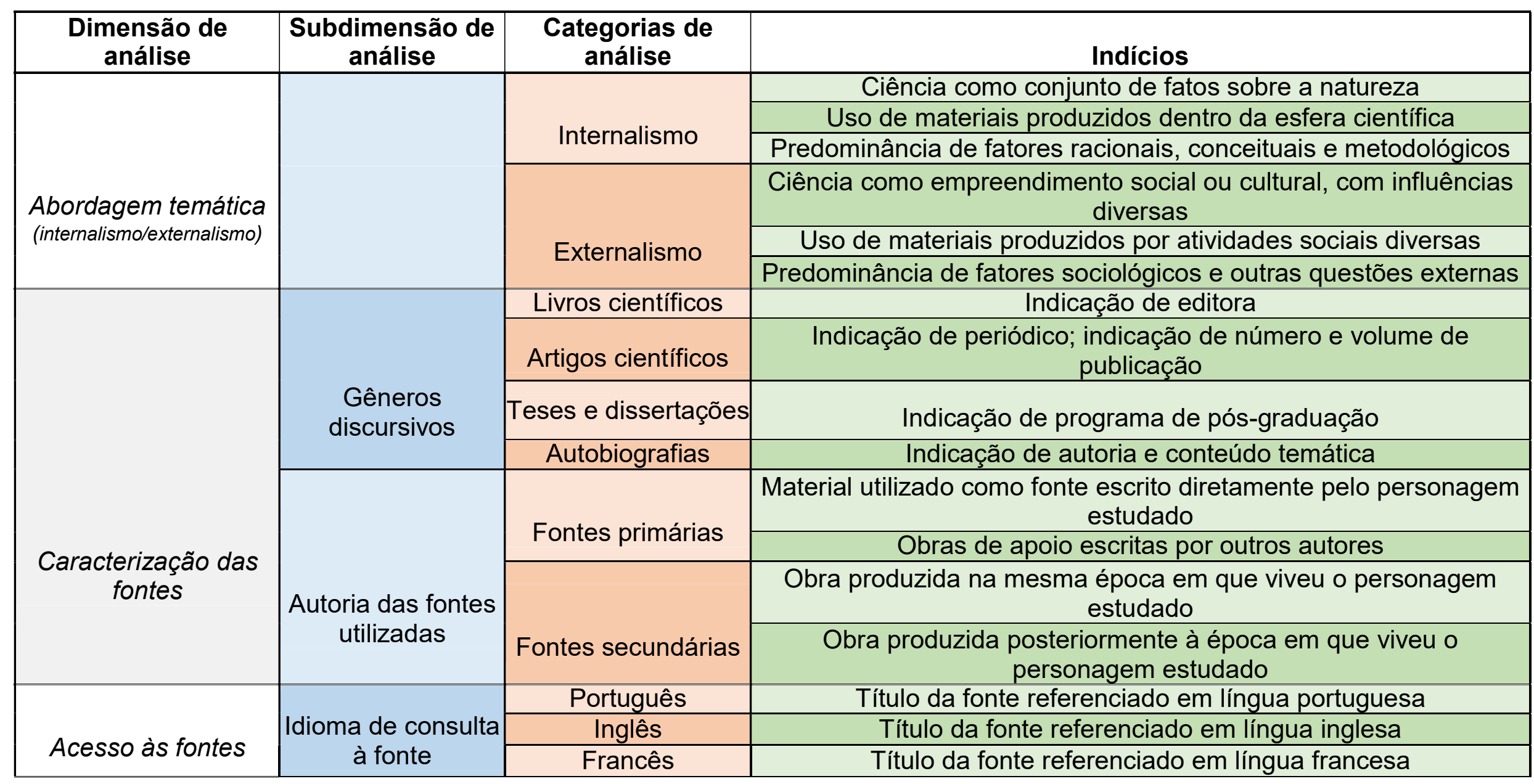




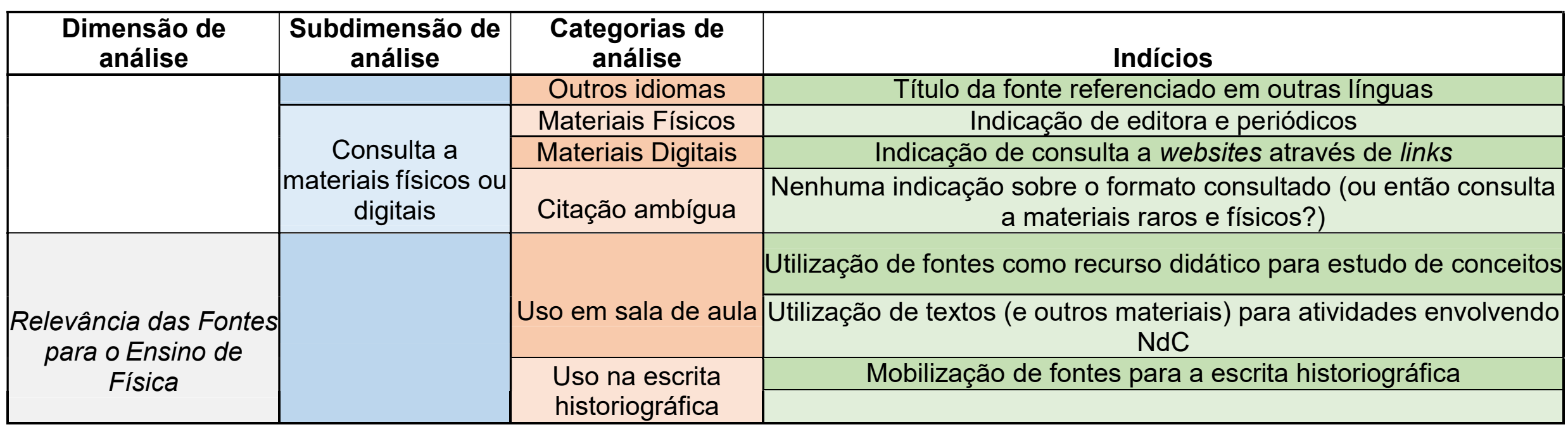

Fonte: Autoria Própria 


\section{APRESENTAÇÃO E ANÁLISE DE DADOS}

Optamos por apresentar os dados utilizando as dimensões de análise, apresentando subitens como as subdimensões que construímos no último capítulo. Ressaltamos um enfoque especial em relação às fontes, embora façamos, também, uma análise da abordagem temática e do papel das fontes no ensino. Cabe lembrar que a análise aqui exposta é referente a todo o conjunto analisado de trabalhos, já explicado no capítulo anterior.

A tabela 2 apresenta o resultado da coleta de dados e consiste do título de cada tese e dissertação seguido do ano de publicação, do orientador e do resumo das fontes utilizadas no relato historiográfico contido naquele trabalho. Compilamos os gêneros das fontes e o idioma conforme indicado pelo autor. A cada trabalho atribuímos um número de 1 a 24 pelo qual nos referiremos ao trabalho na sequência da análise.

Tabela 2: Teses e Dissertações analisadas nessa pesquisa

\begin{tabular}{|c|c|c|c|}
\hline$\#$ & Autor e Título & Orientador & $\begin{array}{l}\text { Resumo das fontes } \\
\text { utilizadas }\end{array}$ \\
\hline 1 & $\begin{array}{l}\text { AURANI, Katya Margareth. } \\
\text { Ensino de conceitos: estudo } \\
\text { das origens da } 2^{\text {a }} \text { Lei da } \\
\text { Termodinâmica e do } \\
\text { Conceito de Entropia a partir } \\
\text { do Século XVIII. Dissertação } \\
\text { de Mestrado. } 1986 .\end{array}$ & $\begin{array}{l}\text { Amélia Império } \\
\text { Hamburguer }\end{array}$ & $\begin{array}{l}6 \text { Fontes Primárias ( } 2 \\
\text { artigos, } 3 \text { livros e uma ata } \\
\text { de evento), } 14 \text { Fontes } \\
\text { Secundárias (dois artigos } \\
\text { científicos, } 7 \text { livros, uma } \\
\text { nota de aula, um artigo de } \\
\text { jornal e três materiais de } \\
\text { divulgação científica). Das } \\
\text { fontes primárias, uma foi } \\
\text { utilizada em inglês, } 4 \text { em } \\
\text { francês e uma em língua } \\
\text { portuguesa. Das fontes } \\
\text { secundárias, } 11 \text { materiais } \\
\text { foram consultados em } \\
\text { inglês e } 3 \text { em português. }\end{array}$ \\
\hline 2 & $\begin{array}{l}\text { ROVIGATTI, Rodinei } \\
\text { Lourenço. O papel da } \\
\text { explicação causal no Ensino } \\
\text { de Física. Dissertação de } \\
\text { Mestrado. } 1987 .\end{array}$ & Alberto Villani & $\begin{array}{l}1 \text { Fonte Primária (um livro } \\
\text { em inglês), } 5 \text { Fontes } \\
\text { Secundárias ( } 5 \text { livros). Das } \\
\text { fontes secundárias, } 4 \text { foram } \\
\text { utilizadas em português e } \\
\text { uma em inglês. }\end{array}$ \\
\hline
\end{tabular}




\begin{tabular}{|c|c|c|c|}
\hline 3 & $\begin{array}{l}\text { HIGA, Teresinha Teruko. } \\
\text { Conservação de Energia: } \\
\text { estudo histórico e } \\
\text { levantamento conceitual dos } \\
\text { alunos. Dissertação de } \\
\text { Mestrado. } 1988 .\end{array}$ & $\begin{array}{l}\text { Ernst Wolfgang } \\
\text { Hamburger }\end{array}$ & $\begin{array}{l}10 \text { Fontes Primárias ( } 3 \\
\text { livros e } 4 \text { artigos } \\
\text { científicos), } 4 \text { Fontes } \\
\text { Secundárias (1 livro, } 1 \text { livro } \\
\text { didático, uma compilação e } \\
\text { um artigo). Das fontes } \\
\text { primárias, } 9 \text { foram } \\
\text { consultadas em inglês e } \\
\text { uma em língua portuguesa; } \\
\text { das fontes secundárias, } \\
\text { duas foram utilizadas em } \\
\text { português, uma em } \\
\text { espanhol e uma em inglês. }\end{array}$ \\
\hline 4 & $\begin{array}{l}\text { VERDEAUX, Maria de } \\
\text { Fátima da Silva. Evolução } \\
\text { histórica do Conhecimento, } \\
\text { utilização e aplicação dos } \\
\text { Raios-X: a relação entre } \\
\text { Ciência, Tecnologia e } \\
\text { Sociedade. Dissertação de } \\
\text { Mestrado. 1989. }\end{array}$ & $\begin{array}{l}\text { Jesuína Lopes } \\
\text { de Almeida } \\
\text { Pacca }\end{array}$ & $\begin{array}{l}33 \text { Fontes Primárias ( } 32 \\
\text { artigos científico e um } \\
\text { artigo de jornal), uma fonte } \\
\text { secundária (um artigo em } \\
\text { inglês). Das fontes } \\
\text { primárias, } 25 \text { foram } \\
\text { utilizadas em inglês, } 5 \text { em } \\
\text { alemão, } 2 \text { em francês e um } \\
\text { em português. }\end{array}$ \\
\hline 5 & $\begin{array}{l}\text { FREIRE JÚNIOR, Olival. } \\
\text { Estudo sobre interpretações } \\
\text { (1927 - 1949) da Teoria } \\
\text { Quântica: Epistemologia e } \\
\text { Física. Dissertação de } \\
\text { Mestrado. 1991. }\end{array}$ & $\begin{array}{l}\text { Amélia Império } \\
\text { Hamburger }\end{array}$ & $\begin{array}{l}4 \text { Fontes Primárias (3 livros } \\
\text { e um artigo, todos em } \\
\text { português), } 13 \text { Fontes } \\
\text { Secundárias ( } 5 \text { artigos, } \\
\text { uma dissertação de } \\
\text { mestrado, } 1 \text { artigo de jornal } \\
\text { e } 6 \text { livros). Das fontes } \\
\text { secundárias, } 10 \text { foram } \\
\text { utilizadas em português, } \\
\text { duas em inglês e uma em } \\
\text { espanhol. }\end{array}$ \\
\hline 6 & $\begin{array}{l}\text { BATISTA, Irinéa de Lourdes. } \\
\text { A concepção física de } \\
\text { Espaço e o ensino de } \\
\text { Mecânica. Dissertação de } \\
\text { Mestrado. 1993. }\end{array}$ & $\begin{array}{l}\text { Maria Regina } \\
\text { Dubeux } \\
\text { Kawamura }\end{array}$ & $\begin{array}{l}2 \text { fontes primárias (dois } \\
\text { livros) e } 7 \text { fontes } \\
\text { secundárias ( } 6 \text { livros e um } \\
\text { artigo. Das fontes } \\
\text { primárias, uma foi utilizada } \\
\text { em francês e outra em } \\
\text { português. Das fontes } \\
\text { secundárias, duas foram } \\
\text { utilizadas em português, } \\
\text { duas em italiano, duas em } \\
\text { inglês e uma em espanhol. }\end{array}$ \\
\hline 7 & $\begin{array}{l}\text { ARRUDA, Sérgio de Mello. } \\
\text { Mudança conceitual na } \\
\text { Teoria da Relatividade } \\
\text { Especial. Dissertação de } \\
\text { Mestrado. } 1994 .\end{array}$ & $\begin{array}{l}\text { Manoel } \\
\text { Roberto } \\
\text { Robilotta }\end{array}$ & $\begin{array}{l}20 \text { fontes primárias ( } 8 \\
\text { artigos, } 3 \text { capítulos de } \\
\text { livros, } 5 \text { compilações e } \\
\text { duas fontes sem } \\
\text { identificação) e } 16 \text { fontes } \\
\text { secundárias ( } 4 \text { livros, } 9\end{array}$ \\
\hline
\end{tabular}




\begin{tabular}{|c|c|c|c|}
\hline & & & $\begin{array}{l}\text { artigos e } 3 \text { sem } \\
\text { identificação). Das fontes } \\
\text { primárias, além das duas } \\
\text { sem identificação, } 12 \text { estão } \\
\text { em inglês, uma em } \\
\text { espanhol e } 3 \text { em português. } \\
\text { As fontes secundárias, } \\
\text { além das } 3 \text { sem } \\
\text { identificação, foram } \\
\text { consultadas em inglês (11), } \\
\text { francês e português (uma } \\
\text { fonte cada); }\end{array}$ \\
\hline 8 & $\begin{array}{l}\text { SIMÕES, Armando Amorim. } \\
\text { A Concepção Dialética do } \\
\text { Conhecimento e o Ensino de } \\
\text { Física. Dissertação de } \\
\text { Mestrado. } 1995 .\end{array}$ & João Zanetic & $\begin{array}{l}8 \text { fontes secundárias. São } 3 \\
\text { livros (sobre história da } \\
\text { ciência), } 3 \text { artigos, um } \\
\text { projeto de ensino e uma } \\
\text { nota de aula. Todas as } \\
\text { fontes foram consultadas } \\
\text { em português. }\end{array}$ \\
\hline 9 & $\begin{array}{l}\text { HENRIQUE, Katia Ferreira. } \\
\text { O Pensamento Físico e o } \\
\text { Pensamento do Senso } \\
\text { Comum: a Energia no } 2^{\circ} \\
\text { grau. Dissertação de } \\
\text { Mestrado. } 1996 .\end{array}$ & $\begin{array}{l}\text { Jesuína Lopes } \\
\text { de Almeida } \\
\text { Pacca }\end{array}$ & $\begin{array}{l}9 \text { fontes secundárias. São } 4 \\
\text { artigos, } 4 \text { livros e uma } \\
\text { dissertação de mestrado. } 4 \\
\text { dessas fontes foram } \\
\text { consultadas em português, } \\
\text { uma em espanhol e quatro } \\
\text { em inglês. }\end{array}$ \\
\hline 10 & $\begin{array}{l}\text { ARAÚJO FILHO, Walter } \\
\text { Duarte de. Galileu e a } \\
\text { Queda de Corpos: Conteúdo } \\
\text { Veiculado nos Livros } \\
\text { Didáticos de Física do } 2^{\circ} \\
\text { Grau: Uma Abordagem } \\
\text { Crítica. Dissertação de } \\
\text { Mestrado. } 1998 .\end{array}$ & $\begin{array}{l}\text { Norberto } \\
\text { Cardoso } \\
\text { Ferreira }\end{array}$ & $\begin{array}{l}1 \text { fonte primária (um livro } \\
\text { consultado em língua } \\
\text { portuguesa). }\end{array}$ \\
\hline 11 & $\begin{array}{l}\text { OLIVEIRA, Ana Maria de. } \\
\text { Pode o ensino de física } \\
\text { prescindir da matemática? - } \\
\text { respostas em estudos } \\
\text { históricos e epistemológicos. } \\
\text { Dissertação de Mestrado. } \\
2001 .\end{array}$ & $\begin{array}{l}\text { Amélia Império } \\
\text { Hamburguer }\end{array}$ & $\begin{array}{l}3 \text { fontes primárias ( } 3 \text { livros, } \\
\text { todos em português) e } 4 \\
\text { fontes secundárias ( } 3 \text { livros } \\
\text { e um artigo, todos em } \\
\text { português). }\end{array}$ \\
\hline 12 & $\begin{array}{l}\text { DONADELLI, Marisilvia. } \\
\text { Exercícios de compreensão } \\
\text { da mecânica quântica, de } \\
\text { seus fenômenos de } \\
\text { correlação à distância e } \\
\text { possíveis aplicações. } \\
\text { Dissertação de Mestrado. } \\
2002 \text {. }\end{array}$ & $\begin{array}{l}\text { Amélia } \\
\text { Império } \\
\text { Hamburger }\end{array}$ & $\begin{array}{l}3 \text { fontes primárias ( } 2 \text { artigos } \\
\text { e } 2 \text { livros) e } 5 \text { fontes } \\
\text { secundárias ( } 5 \text { livros, } \\
\text { sendo } 3 \text { em português em } \\
2 \text { em inglês). As fontes } \\
\text { primárias foram utilizadas } \\
\text { em português (3) e inglês } \\
\text { (1) }\end{array}$ \\
\hline
\end{tabular}




\begin{tabular}{|c|c|c|c|}
\hline 13 & $\begin{array}{l}\text { MOZENA, Erika Regina. A } \\
\text { solução de Planck para o } \\
\text { problema da radiação do } \\
\text { corpo negro (PRCN) e o } \\
\text { ensino de física quântica. } \\
\text { Dissertação de Mestrado. } \\
2003 \text {. }\end{array}$ & João Zanetic & $\begin{array}{l}2 \text { fontes primárias (uma } \\
\text { autobiografia e um livro) e } \\
19 \text { fontes secundárias ( } 3 \\
\text { teses e dissertações, duas } \\
\text { notas de aula, } 6 \text { livros, } 3 \\
\text { artigos científicos, uma } \\
\text { transcrição de palestra, } \\
\text { uma transcrição de } \\
\text { comunicação oral e } 3 \text { livros } \\
\text { didáticos). As fontes } \\
\text { primárias foram } \\
\text { consultadas em inglês. Das } \\
\text { fontes secundárias } \\
\text { utilizadas, } 7 \text { foram } \\
\text { consultadas em inglês e } 12 \\
\text { em português. }\end{array}$ \\
\hline 14 & $\begin{array}{l}\text { GARDELLI, Daniel. } \\
\text { Concepções de interação } \\
\text { física: Subsídios para uma } \\
\text { abordagem histórica do } \\
\text { assunto no ensino médio. } \\
\text { Dissertação de Mestrado. } \\
2004 \text {. }\end{array}$ & $\begin{array}{l}\text { Roberto de } \\
\text { Andrade } \\
\text { Martins }\end{array}$ & $\begin{array}{l}5 \text { fontes primárias (uma } \\
\text { enciclopédia, } 2 \text { livros e } 2 \\
\text { artigos) e } 26 \text { fontes } \\
\text { secundárias ( } 7 \text { livros, } 5 \\
\text { dicionários, } 11 \text { artigos, } 1 \\
\text { artigo de divulgação } \\
\text { científica, } 1 \text { revista, } 1 \\
\text { comunicação oral). Das } \\
\text { fontes primárias, } 4 \text { foram } \\
\text { utilizadas em inglês e uma } \\
\text { em português. Das fontes } \\
\text { secundárias, } 22 \text { foram } \\
\text { utilizadas em inglês e } 4 \text { em } \\
\text { português. }\end{array}$ \\
\hline 15 & $\begin{array}{l}\text { DELGADO, Nely Magdalena } \\
\text { Barrios. Concepções } \\
\text { alternativas e conhecimento } \\
\text { científico: contribuições para } \\
\text { o problema da } \\
\text { incompatibilidade teórica em } \\
\text { ensino de ciências. } \\
\text { Dissertação de Mestrado. } \\
2005 \text {. }\end{array}$ & $\begin{array}{l}\text { Norberto } \\
\text { Cardoso } \\
\text { Ferreira }\end{array}$ & $\begin{array}{l}3 \text { fontes secundárias. São } \\
\text { dois artigos e uma nota em } \\
\text { aula. Dessas fontes, duas } \\
\text { foram utilizadas em inglês e } \\
\text { uma em português. }\end{array}$ \\
\hline 16 & $\begin{array}{l}\text { GURGEL, Ivã. A imaginação } \\
\text { científica como componente } \\
\text { do entendimento: subsídios } \\
\text { para o ensino de física. } \\
\text { Dissertação de Mestrado. } \\
2006 .\end{array}$ & $\begin{array}{l}\text { Maurício } \\
\text { Pietrocola Pinto } \\
\text { de Oliveira }\end{array}$ & $\begin{array}{l}6 \text { fontes primárias (uma } \\
\text { autobiografia, dois livros, } \\
\text { um artigo e duas } \\
\text { compilações de cartas) e } 3 \\
\text { fontes secundárias ( } 2 \text { livros } \\
\text { e um artigo). Das fontes } \\
\text { primárias, } 4 \text { foram } \\
\text { utilizadas em português e } \\
\text { duas em francês e, das } \\
\text { fontes secundárias, duas }\end{array}$ \\
\hline
\end{tabular}




\begin{tabular}{|c|c|c|c|}
\hline & & & $\begin{array}{l}\text { em português e uma em } \\
\text { francês. }\end{array}$ \\
\hline 17 & $\begin{array}{l}\text { BARCELLOS, Marcília Elis. } \\
\text { História, sociologia, massa e } \\
\text { energia: Uma reflexão sobre } \\
\text { a formação de } \\
\text { pesquisadores em física. } \\
\text { Dissertação de Mestrado. } \\
2008 .\end{array}$ & João Zanetic & $\begin{array}{l}2 \text { fontes primárias (um } \\
\text { material de divulgação } \\
\text { científica e uma } \\
\text { autobiografia) e } 9 \text { fontes } \\
\text { secundárias ( } 4 \text { artigos e } 5 \\
\text { livros). As fontes primárias } \\
\text { foram utilizadas em } \\
\text { português e, das fontes } \\
\text { secundárias, } 8 \text { foram } \\
\text { utilizadas em português e } \\
\text { uma em inglês. }\end{array}$ \\
\hline 18 & $\begin{array}{l}\text { PEREIRA, Rafael Andrade. } \\
\text { A física da música no } \\
\text { Renascimento: uma } \\
\text { abordagem histórico- } \\
\text { epistemológica. Dissertação } \\
\text { de Mestrado. } 2010 .\end{array}$ & $\begin{array}{l}\text { Oscar João } \\
\text { Abdounur }\end{array}$ & $\begin{array}{l}2 \text { fontes primárias (duas } \\
\text { fontes sem identificação) e } \\
3 \text { fontes secundárias ( } 2 \\
\text { livros em português e uma } \\
\text { ata de seminário, também } \\
\text { em português). }\end{array}$ \\
\hline 19 & $\begin{array}{l}\text { HENRIQUE, Alexandre } \\
\text { Bagdonas. Discutindo a } \\
\text { natureza da ciência a partir } \\
\text { de episódios da história da } \\
\text { cosmologia. Tese de } \\
\text { Doutorado. } 2015 .\end{array}$ & $\begin{array}{l}\text { Cibelle } \\
\text { Celestino Silva }\end{array}$ & $\begin{array}{l}8 \text { fontes primárias (4 livros } \\
\text { e } 4 \text { artigos, todos em } \\
\text { inglês) e } 30 \text { fontes } \\
\text { secundárias ( } 7 \text { livros, duas } \\
\text { dissertações, } 15 \text { artigos, } 1 \\
\text { filme, duas transcrições de } \\
\text { comunicação oral e três } \\
\text { materiais de divulgação } \\
\text { científica). Das fontes } \\
\text { secundárias, } 15 \text { foram } \\
\text { utilizadas em inglês e } 15 \\
\text { em português. }\end{array}$ \\
\hline 20 & $\begin{array}{l}\text { ALBUQUERQUE, Vanessa } \\
\text { Nóbrega de. O caso Plutão e } \\
\text { a natureza da ciência: uma } \\
\text { proposta para alunos do } \\
\text { ensino médio. Dissertação } \\
\text { de Mestrado. } 2012 \text {. }\end{array}$ & Cristina Leite & $\begin{array}{l}2 \text { fontes primárias (um livro } \\
\text { e uma ata de assembleia, } \\
\text { sendo as duas em inglês) e } \\
8 \text { fontes secundárias ( } 2 \\
\text { livros, uma nota de aula, } \\
\text { dois artigos e } 3 \text { materiais } \\
\text { de divulgação científico). } \\
\text { Das fontes secundárias, } \\
\text { uma foi utilizada em inglês, } \\
6 \text { em português e uma em } \\
\text { espanhol. }\end{array}$ \\
\hline 21 & $\begin{array}{l}\text { SILVA, Djalma Nunes da. } \\
\text { Ensino e aprendizagem da } \\
\text { termodinâmica: questões } \\
\text { didáticas e contribuições da } \\
\text { história da ciência. Tese de } \\
\text { Doutorado. } 2013 \text {. }\end{array}$ & $\begin{array}{l}\text { Jesuína Lopes } \\
\text { de Almeida } \\
\text { Pacca }\end{array}$ & $\begin{array}{l}8 \text { fontes primárias ( } 7 \text { livros } \\
\text { e um artigo) e } 13 \text { fontes } \\
\text { secundárias ( } 8 \text { livros, uma } \\
\text { enciclopédia, duas teses ou } \\
\text { dissertações, um artigo e } \\
\text { uma fonte sem } \\
\text { identificação). Das fontes } \\
\text { primárias, } 5 \text { foram }\end{array}$ \\
\hline
\end{tabular}




\begin{tabular}{|c|c|c|c|}
\hline & & & $\begin{array}{l}\text { utilizadas em francês, uma } \\
\text { em espanhol, uma em latim } \\
\text { e uma em inglês. Das } \\
\text { fontes secundárias, duas } \\
\text { foram consultadas em } \\
\text { inglês, uma em francês e } 9 \\
\text { em português, além de } \\
\text { uma sem identificação. }\end{array}$ \\
\hline 22 & $\begin{array}{l}\text { CAMPOS, Alexandre. A } \\
\text { conceitualização do princípio } \\
\text { de conservação da energia } \\
\text { mecânica: os processos de } \\
\text { aprendizagem e a teoria dos } \\
\text { campos conceituais. Tese de } \\
\text { Doutorado. } 2014 \text {. }\end{array}$ & $\begin{array}{l}\text { Elio Carlos } \\
\text { Ricardo }\end{array}$ & $\begin{array}{l}\text { Duas fontes primárias (dois } \\
\text { livros, um em francês e um } \\
\text { em inglês) e } 5 \text { fontes } \\
\text { secundárias ( } 3 \text { livros e dois } \\
\text { artigos). Das fontes } \\
\text { secundárias, duas foram } \\
\text { utilizadas em português e } 3 \\
\text { em inglês. }\end{array}$ \\
\hline 23 & $\begin{array}{l}\text { LUIZ, Danilo Cardoso } \\
\text { Rodrigues. A } \\
\text { complementariedade dos } \\
\text { pensamentos narrativo e } \\
\text { matemático na gestação da } \\
\text { teoria da relatividade geral. } \\
\text { Dissertação de Mestrado. } \\
2015 .\end{array}$ & Ivã Gurgel & $\begin{array}{l}6 \text { fontes primárias (três } \\
\text { artigos, uma carta, uma } \\
\text { autobiografia e um livro de } \\
\text { divulgação científica) e } 6 \\
\text { fontes secundárias (4 } \\
\text { artigos, uma dissertação e } \\
\text { um livro). Das fontes } \\
\text { primárias, } 4 \text { foram } \\
\text { utilizadas em português. } \\
\text { Das fontes secundárias, } 3 \\
\text { foram utilizadas em } \\
\text { português e } 3 \text { em inglês. }\end{array}$ \\
\hline 24 & $\begin{array}{l}\text { CARVALHO, Tassiana } \\
\text { Fernanda Genzini de. Da } \\
\text { divulgação ao ensino: um } \\
\text { olhar para o céu. } \\
\text { Dissertação de Mestrado. } \\
2016 .\end{array}$ & $\begin{array}{l}\text { Jesuína Lopes } \\
\text { de Almeida } \\
\text { Pacca }\end{array}$ & $\begin{array}{l}10 \text { fontes secundárias. } \\
\text { Todas as fontes foram } \\
\text { utilizadas em português, } \\
\text { sendo } 4 \text { livros, } 4 \text { teses e } \\
\text { dissertações e duas atas } \\
\text { de congresso. }\end{array}$ \\
\hline
\end{tabular}

Fonte: Autoria Própria

\subsection{Orientadores}

Ao sistematizar o conjunto de dados para análise, notamos que há um aspecto muito relevante que possibilitaria um entendimento mais amplo da produção do PIEC: os professores orientadores das teses e dissertações. A tabela 3 condensa, a partir dos 51 dados previamente encontrados na interface do $\mathrm{EC}$ com a $\mathrm{HC}$, o número de trabalhos orientados por cada professor do programa: 
Tabela 3: Quantidade de trabalhos por orientador na interface entre EC e HC do

PIEC

\begin{tabular}{|l|l|}
\hline Orientador(a) & $\begin{array}{l}\text { Número de } \\
\text { Trabalhos }\end{array}$ \\
\hline João Zanetic & 13 \\
\hline Amélia Império Hamburger & 10 \\
\hline $\begin{array}{l}\text { Jesuína Lopes de Almeida } \\
\text { Pacca }\end{array}$ & 6 \\
\hline Alberto Villani & 2 \\
\hline Anna Maria Pessoa de Carvalho & 2 \\
\hline Cibelle Celestino Silva & 2 \\
\hline Ernst Wolfgang Hamburguer & 2 \\
\hline Ivã Gurgel & 2 \\
\hline Manoel Roberto Robilotta & 2 \\
\hline Norberto Cardoso Ferreira & 2 \\
\hline Cristina Leite & 1 \\
\hline Elio Carlos Ricardo & 1 \\
\hline Luís Carlos de Menezes & 1 \\
\hline $\begin{array}{l}\text { Maria Regina Dubeux } \\
\text { Kawamura }\end{array}$ & 1 \\
\hline Maurício Pietrocola Pinto de \\
Oliveira & 1 \\
\hline Oscar João Abdounur & 1 \\
\hline Paulo Alves Porto & 1 \\
\hline Roberto de Andrade Martins & 1 \\
\hline
\end{tabular}

Fonte: Autoria própria. Construída a partir da lista de teses e dissertações fornecida pela secretaria do PIEC.

A tabela 3 acima apresenta alguns dados particularmente interessantes. $O$ primeiro deles é que três professores respondem por 56,8 \% da orientação dos trabalhos, indicando um duradouro interesse desses orientadores na temática de História da Ciência. O segundo resultado é que oito professores orientaram um único trabalho nessa linha até o momento da coleta de dados desta dissertação. Ao consultar a página online do PIEC é possível notar que vários desses professores atuam em outras linhas de pesquisas, mostrando certa flexibilidade do programa à pesquisa em múltiplas temáticas de pesquisa.

Há uma tendência bastante interessante que surge ao analisar os primeiros trabalhos produzidos no PIEC na linha de pesquisa de história da ciência. A tabela a seguir organiza os orientadores desses trabalhos e suas respectivas áreas de formação: 
Tabela 4 - Orientadores dos Primeiros Trabalhos do PIEC

\begin{tabular}{|l|l|}
\hline Orientador(a) & Área de formação \\
\hline Luís Carlos de Menezes & Mecânica Estatística \\
\hline Ernst Wolfgang Hamburguer & Física Nuclear \\
\hline Alberto Villani & Física de Partículas \\
\hline Manoel Roberto Robilotta & Física Nuclear \\
\hline Amélia Império Hamburger & Física Nuclear \\
\hline Jesuína Lopes de Almeida Pacca & Educação \\
\hline Maria Regina Dubeux Kawamura & Biofísica \\
\hline Anna Maria Pessoa de Carvalho & Educação \\
\hline
\end{tabular}

Fonte: Autoria própria.

Os primeiros orientadores do programa foram formados como pesquisadores em áreas da física "dura". Alguns anos depois, alguns professores orientadores provindos originalmente da área de educação foram integrados ao corpo docente do PIEC. Essa tendência pode ser localizada no próprio desenvolvimento da área de Ensino de Ciências. Muitos dos primeiros pesquisadores vieram das suas respectivas áreas das ciências "duras" seguidos dos pesquisadores formados na área de educação.

\subsection{Internalismo e externalismo}

Como exploramos anteriormente, a própria concepção de internalismo e externalismo se alterou ao longo do tempo, passando de uma abordagem mais dicotômica e polarizada para uma noção mais fluida e menos rígida.

Essa questão é de extrema importância para o ensino de ciências, já que forma um conjunto de valores que os pesquisadores (e, em alguns casos, professores e alunos envolvidos com os resultados das pesquisas que analisamos) compartilham como sendo importantes para a definição de ciência. A depender da rigidez de um determinado ponto de vista, a ciência pode ser encarada de um modo desconectado dos fatores sociais ou plenamente determinados por ele, sem uma epistemologia específica.

O conjunto de dados analisados apresenta algumas tendências que havíamos conjecturado a partir da discussão teórica. A mais relevante delas é uma predominância da abordagem internalista, mas que reconhece a existência de fatores 
externos e sociais. Dessa forma, a composição geral dos trabalhos apresenta uma perspectiva internalista, com breves considerações sobre os fatores extra científicos.

A apreensão dessa análise geral encontra diferentes manifestações em diferentes trabalhos. Todos os trabalhos analisados são categorizados como predominantemente internalistas a partir dos indícios construídos no final do capítulo anterior. Assim, notamos características comuns aos trabalhos, em especial algumas levantadas a seguir:

- Ciência como conjunto de fatos sobre a natureza: o modo como a mudança dos conceitos é tratada e a exposição da construção de teorias científica revela, através desses trabalhos, predominantemente uma função referencial da ciência. Isso indica que os autores, embora entendam que há diversos fatores que influenciam as mudanças das teorias científicas, o mais importante para a definição de ciência é sua capacidade de se ajustar às novas evidências e descobertas de fenômenos.

- Seleção das fontes utilizadas: como veremos adiante, as fontes utilizadas, em especial as fontes primárias, são predominantemente produzidas em atividades científicas, como artigos científicos e livros acadêmicos. Tradicionalmente, esses materiais, quando produzidos na área de física, não discutem sobre aspectos culturais e externos à ciência. Mesmo através das fontes secundárias, muitas das quais também se tratam de fontes predominantemente internalistas, a abordagem se sustenta tratando, essencialmente, dos aspectos internos à ciência.

- $\quad$ O último indício da tabela pode ser compreendido no conjunto dessa discussão que apresentamos nesse subitem. Cabe ressaltar, entretanto, que além da apreensão através dos indícios, também notamos que os pesquisadores do PIEC têm conhecimento dessa discussão e, eventualmente, buscam se posicionar explicitamente.

Um dos critérios utilizados para classificar os trabalhos como internalista foi a presença da indicação implícita dessa tendência na descrição dos objetivos e características gerais da escrita do relato historiográfico. O trabalho número 17 (BARCELLOS, 2008), por exemplo, faz uma longa exposição matemática dos principais conceitos que levaram ao surgimento da equação $E=m c^{2}$. Outro exemplo é o trabalho 16 (GURGEL, 2006) que traz uma interface com a filosofia. Tal abordagem foca, portanto, nas mudanças conceituais impulsionadas por processos 
racionais, característica exigida pelo conhecimento científico.

Alguns casos, entretanto, optam por uma discussão mais explícita e densa sobre as metodologias historiográficas, incluindo, em tal discussão, um posicionamento específico sobre a abordagem historiográfica. Citamos, aqui, alguns exemplos:

\begin{abstract}
Nossa pesquisa tomará como enfoque o interesse por características mais internas sobre o funcionamento da ciência, em particular, como o pensamento de um cientista se consolida para interpretar os fenômenos da Natureza. (T23. LUIZ, 2015, p. 79)
\end{abstract}

Sendo assim, ao considerarmos que as perspectivas filosóficas expostas no primeiro capítulo encontram-se num domínio acima dos conceitos científicos, voltaremos nossa atenção agora para a discussão de conceitos científicos (T22. CAMPOS, 2014, p. 76, grifos nossos)

Além desses exemplos, destacamos também o trabalho 3 (HIGA, 1987), que, ao fazer considerações sobre a historiografia da ciência, reconhece brevemente a influência de fatores externos no desenvolvimento científico. Essa autora reconhece que incluir essas considerações externalistas na pesquisa constitui detalhes fora de sua área original de formação, mas que são componentes importantes na construção de uma narrativa crítica do desenvolvimento da ciência.

De modo geral, o internalismo apresentado pelos trabalhos do programa pode ser caracterizado pelo enfoque na mudança dos conceitos causada por fatores predominantemente científicos mas que reconhece fatores sociais em geral. São poucas excessões a essa tendência, como os trabalhos 6, 7, 8, 11 e 12.

Interpretamos isso como uma preocupação dos autores de que o ensino de ciências, aliado à história da ciência, cumpra a função de esclarecer alguns aspectos da natureza da atividade científica. Em partes, isso inclui enaltecer os aspectos que fazem da atividade científica algo valioso em termos epistemológicos, digno de confiança por causa de características específicas, compreendidas por meio da própria natureza da ciência.

Um dos fatores que os próprios autores apresentam para a escolha dessa abordagem é uma restrição proposital do escopo do relato historiográfico, o que nos permite inferir que a história da ciência no ensino tende a enfocar os aspectos lógicos da ciência, mas sem rejeitar outros aspectos externalistas.

Gostaríamos, por fim, de ressaltar que identificamos poucos trabalhos com uma 
abordagem exclusivamente internalista, uma vez que entendemos a diferença entre internalismo e externalismo de forma mais fluida, admitindo a existência de abordagens intermediárias, conforme discutimos anteriormente. Entretanto, caracterizamos a produção como próxima a essa abordagem, uma vez que aborda predominantemente os aspectos lógicos da ciência. É possível, entretanto, encontrar alguns momentos em que os autores citam alguns fatores diversos (como política, cultura, religião), apesar de não explorá-los de modo mais sistemático.

\subsection{Fontes}

Respeitando as divisões que sugerimos no final do capítulo anterior, apresentamos agora um dos frutos principais desse trabalho, que se constitui da análise das fontes utilizadas nos trabalhos analisados.

Nos guiamos especialmente pelas referências bibliográficas feitas pelos autores, pressupondo que estes preocuparam-se em manter um registro fidedigno das fontes utilizadas. Essa estratégia funcionou relativamente bem e nos permitiu entender vários aspectos interessante do uso das fontes, mas ressaltamos algumas restrições nesse método:

- Dois trabalhos não incluem as referências de modo sistemático. Utilizando o método documental, é impossível entender a dinâmica de uso das fontes nesses materiais. Para tanto, outros métodos poderiam ter sido utilizados, como entrevistas. O trabalho 18 (PEREIRA, 2010), cita as fontes no texto sem detalhá-las na bibliografia e o trabalho 6 (BATISTA, 1993), cita na bibliografia, mas sem detalhar sua utilização no texto.

- Outros trabalhos são extremamente longos e referem-se a diversas fontes diferentes de naturezas diferentes, tornando o processo de leitura algo extremamente árduo. De modo geral, optamos pela leitura dos capítulos que apresentaram algum relato historiográfico. Para o trabalhos 11 , constituído de um único relato que ocupa toda sua extensão, analisamos o capítulo 5 (A Física e Matemática na Europa).

- $\quad$ Analisando apenas as referências em termos de contexto de uso e de frequência de citações, eventualmente encontramos fontes utilizadas para elucidar alguns aspectos bastante detalhistas e pontuais. Mesmo essas fontes entraram na nossa análise, contabilizando para o resultado final. Isso occorreu, por exemplo, no 
trabalho 9 (HENRIQUE, 1996), que citou pontualmente um livro de Mach (no contexto desse trabalho, tal livro é uma fonte secundária).

\subsubsection{Gêneros discursivos}

De modo mais específico, seguindo o referencial teórico bakhtiniano que utilizamos, chamaremos essas construções de gêneros discursivos, entendendo que cada uma delas (seja livro, seja artigo, carta, etc) é fruto de um processo histórico determinado por condições específicas e que estão presentes na utilização das fontes pelos pesquisadores.

A criação desta subdimensão de análise nos permitiu atingir parte de nosso objetivo de pesquisa, ou seja, caracterizar a composição das fontes que os autores mais utilizam no decorrer de suas pesquisas historiográficas. Apresentaremos, pois, nossas principais descobertas em relação a esse tópico.

De modo geral, a análise dos dados revela a utilização proeminente de artigos e livros científicos e acadêmicos como fontes de dados historiográficos. Como há uma diferença entre a utilização de algumas construções como fontes primárias e secundárias, a proporção da utilização será explorada no próximo subitem. Cabe, aqui, a interpretação do contexto de uso das principais fontes.

Assim sendo, como forma de inferência a partir do que os autores permitem transparecer pelos seus relatos historiográficos, construímos uma tabela identificando as principais características das fontes utilizadas (caracterizando do ponto de vista bakhtiniano) e apresentamos também as características discursivas de cada fonte (do ponto de vista da própria utilização), considerando o contexto de uso das fontes mais frequentes:

Tabela 5 - Gêneros discursivos identificado no conjunto de dados analisados

\begin{tabular}{|c|c|c|}
\hline Fontes & Características discursivas & Contexto de uso \\
\hline Livros & Conteúdos acadêmicos & Como fonte secundária, \\
científicos e & referentes ao & se tratando \\
acadêmicos & desenvolvimento de teorias & principalmente de livros \\
& científicas. O estilo & sobre histórias da \\
& linguístico & ciência, os autores \\
& envolve uma linguagem & citam essas fontes \\
\hline
\end{tabular}




\begin{tabular}{|c|c|c|}
\hline & $\begin{array}{c}\text { neutra e técnica, muitas } \\
\text { vezes marcado pela } \\
\text { presença de equações } \\
\text { matemáticas, especialmente } \\
\text { nos livros da área de física. }\end{array}$ & $\begin{array}{c}\text { numa extensão maior } \\
\text { do texto, indicando que } \\
\text { foi utilizada mais frequentemente } \\
\text { para que o autor obtivesse um } \\
\text { entendimento mais amplo do } \\
\text { período estudado. Como fonte } \\
\text { primária, o uso se assemelha ao } \\
\text { dos artigos científicos, marcado } \\
\text { principalmente pela citação } \\
\text { próxima ao desenvolvimento de } \\
\text { equações, marcando a relevância } \\
\text { dessa modalidade de fontes para } \\
\text { esse tipo de } \\
\text { abordagem. }\end{array}$ \\
\hline $\begin{array}{c}\text { Artigos } \\
\text { científicos }\end{array}$ & $\begin{array}{c}\text { Resultados de pesquisas } \\
\text { científicas e acadêmicas. } \\
\text { Uma característica do } \\
\text { conteúdo temático dos } \\
\text { artigos, que é semelhante } \\
\text { dos livros acadêmicos, é a } \\
\text { presença de equações } \\
\text { matemáticas aproveitadas } \\
\text { pelos autores. }\end{array}$ & $\begin{array}{l}\text { Como fonte primária, os artigos } \\
\text { foram utilizados para apresentar } \\
\text { aspectos teóricos e matemáticos } \\
\text { sobre as teorias científicas. } \\
\text { Como fontes secundárias, o uso } \\
\text { foi semelhante ao uso dos livros, } \\
\text { especialmente porque também se } \\
\text { tratam de trabalhos da área de } \\
\text { história da ciência e, } \\
\text { eventualmente, da área } \\
\text { de ensino também. }\end{array}$ \\
\hline $\begin{array}{c}\text { Teses e } \\
\text { Dissertações }\end{array}$ & $\begin{array}{l}\text { Esses tipos de fontes têm a } \\
\text { característica de serem } \\
\text { relatórios de pesquisa } \\
\text { desenvolvida em programa } \\
\text { de pós-graduação. São } \\
\text { todas fontes secundárias } \\
\text { nacionais que apresentam } \\
\text { relatos historiográficos e }\end{array}$ & $\begin{array}{l}\text { Esses tipos de fonte são, } \\
\text { basicamente, utilizadas como } \\
\text { fontes secundárias. Inferimos que } \\
\text { os autores utilizam essas fontes } \\
\text { com o uso semelhante ao dos } \\
\text { livros, para esclarecer aspectos } \\
\text { internos específicos da história } \\
\text { do objeto estudado. }\end{array}$ \\
\hline
\end{tabular}




\begin{tabular}{|c|c|c|}
\hline & $\begin{array}{c}\text { foram produzidos no âmbito } \\
\text { de programas de ensino de } \\
\text { ciências. }\end{array}$ & \\
\hline Cartas & $\begin{array}{c}\text { Conteúdo relativo a } \\
\text { relacionamentos e diálogos } \\
\text { em geral, com conteúdo } \\
\text { temático diverso e estilo } \\
\text { mais pessoal e, } \\
\text { eventualmente, informal. }\end{array}$ & $\begin{array}{l}\text { Apesar de apresentarem conteúdo } \\
\text { diverso, as cartas são utilizadas } \\
\text { para esclarecer aspectos do } \\
\text { pensamento do cientista } \\
\text { estudado. Além disso, identifica- } \\
\text { se também o uso de possíveis } \\
\text { reações a proposições } \\
\text { científicas. }\end{array}$ \\
\hline Autobiografias & $\begin{array}{c}\text { História da vida de uma } \\
\text { pessoa escrita por ela } \\
\text { mesmo. Geralmente aparece } \\
\text { como um relato em primeira } \\
\text { pessoa com a utilização de } \\
\text { um estilo bastante pessoal. }\end{array}$ & $\begin{array}{c}\text { Quando utilizada, essa } \\
\text { modalidade de fonte apresentou } \\
\text { aspectos específicos do } \\
\text { pensamento de um } \\
\text { determinado cientista. }\end{array}$ \\
\hline
\end{tabular}

Fonte: Autoria própria com base nos dados analisados.

De modo geral, identificamos que as outras fontes (apontadas no gráfico 2) apresentam usos pontuais e semelhantes entre si. Assim, essa tabela foi construída para exemplificar como algumas das fontes mais relevantes foram utilizadas pelos autores do PIEC.

\subsubsection{Fontes primárias ou secundárias}

Como parte da caracterização que estamos propondo, cabe quantificar e entender alguns aspectos sobre a utilização das fontes primárias. Como já dito, as fontes primárias são aquelas cuja produção está diretamente ligada com o objeto ou período de estudo. As fontes secundárias são aquelas produzidas por autores em outros períodos.

No contexto desse trabalho, a análise das fontes primárias e secundárias está intimamente ligada às outras dimensões e subdimensões de análise. Entretanto, construímos dois gráficos para mostrar como as diferenças entre as fontes primárias 
estão relacionadas com as diferenças de idiomas e gêneros discursivos.

Além das diferenças em termos discursivos, pudemos também confirmar, quantitativamente, uma hipótese. Imaginamos que, devido a impossibilidades e facilidades de acesso, as fontes secundárias seriam mais frequentes do que as fontes primárias, dada a própria natureza dessas fontes. Identificamos 120 fontes primárias e 221 fontes secundárias nas 24 teses e dissertações estudadas.

Gráfico 2 - Gêneros Discursivos presentes nas fontes primárias

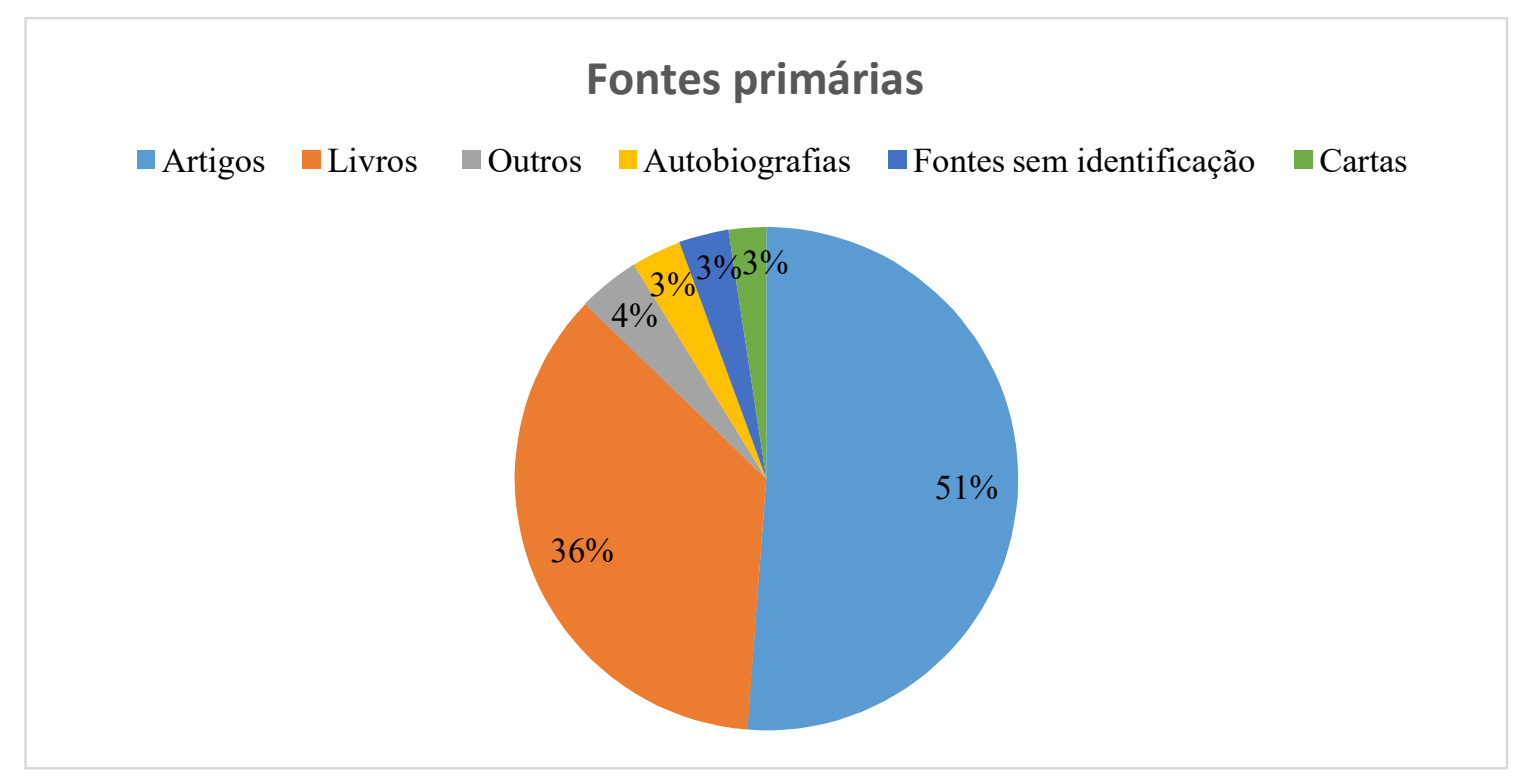

Fonte: Autoria própria com base nos dados analisados.

Para as fontes primárias pudemos notar que os autores tendem a utilizar um maior volume de artigos científicos. Nesse caso, como se tratam de fontes primárias, tratam-se de artigos sobre a área de Física, assim como os livros são compostos de tratados científicos e materiais semelhantes. Como explorado anteriormente, a utilização maior de artigos e livros científicos está em concordância com uma abordagem internalista. A seguir apresentamos um gráfico semelhante, mas para as fontes secundárias: 
Gráfico 3 - Gêneros Discursivos presentes nas fontes secundárias

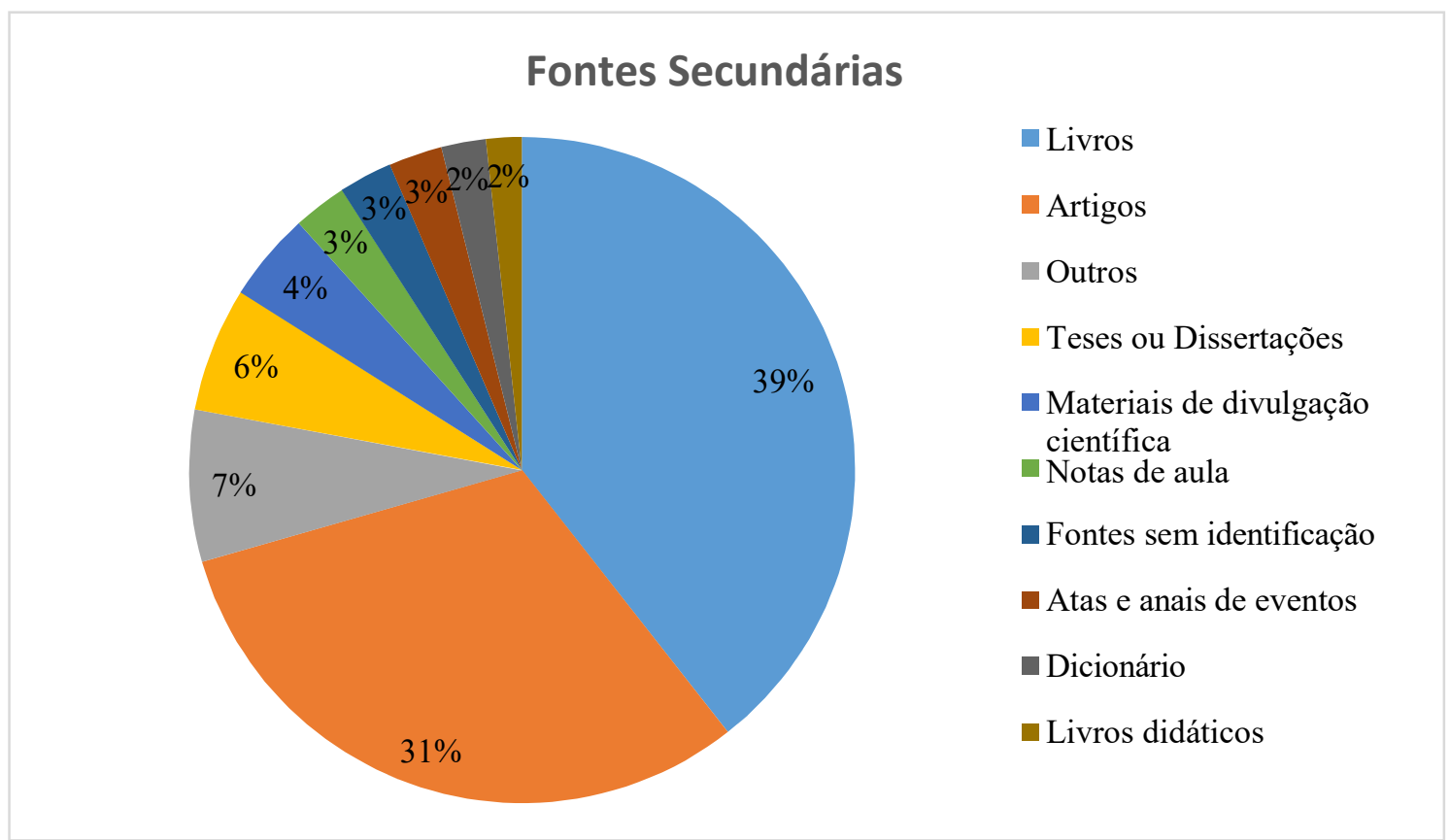

Fonte: Autoria própria com base nos dados analisados.

Nota-se uma tendência semelhante à utilização das fontes primárias, apesar dos artigos e livros utilizados serem pertencentes a áreas diferentes (história da ciência e ensino de ciências).

Aqui há uma diferença que é relevante. Há uma série de materiais diferentes que são utilizados também, como atas de eventos, notas de aula, dissertações e teses e outros, que desempenham um papel relevante em algumas teses e dissertações. Esses materiais, de modo geral, são discursos construídos sempre se referindo a um grupo de conhecimentos já estabelecidos.

Por último, gostaríamos de ressaltar que identificamos também uma modalidade de fonte secundária que tem um papel bastante relevante na produção historiográfica e serve bastante de auxílio para os autores desse programa, em especial por facilitar o acesso às fontes primárias. Tratam-se das compilações de artigos e textos. Através desses materiais os autores têm à disposição um leque bem maior de textos primários para utilizar em seus trabalhos. Citamos aqui alguns exemplos: o trabalho 3 (HIGA, 1987) apresenta o uso de uma compilação de artigos de Julius Mayer traduzidos para língua inglesa; Os artigos de Niels Bohr consultados pela autora do trabalho 12 (DONADELLI, 2002) também foram consultados em uma compilação traduzida. As cartas de Albert Einstein consultadas pelo autor do trabalho 16 (GURGEL, 2006) foram compiladas e publicadas em francês. 
De modo geral, reconhecemos um uso bastante específico das fontes secundárias, em especial quando são compostas de relatos historiográficos. Através delas, os autores obtêm aspectos variados sobre o período estudando. Em outras palavras, as fontes secundárias em geral permitem aos autores um conhecimento geral sobre o episódio estudado para, então, construírem sua própria interpretação do objeto de estudo. Uma excessão a essa tendência se apreende, entretanto, da análise do trabalho 10 (ARAÚJO FILHO, 1998). No capítulo 5, o autor constrói seu relato baseado em uma fonte primária de Galileu Galilei que foi traduzida e publicada em português.

Também é possível encontrar ao menos duas posturas diferentes em relação ao uso de fontes secundárias e a abordagem historiográfica. Alguns trabalhos justificam a utilização predominante de fontes secundárias por não se tratarem de trabalhos puramente de história da ciência:

No caso dos trabalhos de Einstein foram consultadas fontes originais. Os outros dados históricos são de fontes secundárias. Aqui é necessário enfatizar que este não é um trabalho de história da física, mas de aplicação dessa história no ensino de ciências, assim, a não ser no que se refere aos trabalhos de Einstein, não recorremos à leitura de textos originais e sim aos trabalhos de historiadores que trabalharam com esse tema. (T17, BARCELLOS, 2008, p. 57)

O estudo histórico aqui apresentado foi baseado principalmente no uso de fontes secundárias. Por não ser o foco principal da pesquisa, julgamos que não haveria tempo suficiente para o desenvolvimento de um estudo profundo com o uso de metodologia adequada, pautada no uso predominante de fontes primárias (T19, HENRIQUE, 2015, p. 67)

É importante ressaltar que o resultado dessa análise é decorrente da própria metodologia que escolhemos para entender a construção desses trabalhos. Esse resultado vem da frequência de citação dessas fontes secundárias e do contexto dessas citações.

\subsubsection{Acesso às fontes}

Como discutimos anteriormente, a questão do acesso é uma das mais relevantes da historiografia da ciência, pois o acesso a uma fonte está cercada de vários fatores, tais como:

1. Acesso do material físico ou digitalizado

2. Idioma original/tradução e consulta de determinados idiomas 
3. Disponibilidade de publicação de determinados materiais

De modo geral, em relação ao acesso das fontes via digitalização e/ou materiais físicos, nossa análise pôde constatar que há uma certa imprecisão no modo como os autores representam como se deu o acesso aos materiais estudados. A maioria dos trabalhos, em especial aqueles produzidos após a década de 1990, seguem as normalizações da ABNT, que sugerem a utilização de um modelo padrão para a representação de determinadas formas de produções, como os artigos e livros.

A norma prevê a identificação de algumas características relevantes para a identificação desses materiais, como a o título completo, o autor, o ano de publicação e edição, o periódico (quando se tratando de artigos) e editora (quando se trata de livros). A princípio, essa mesma norma também sugere a identificação de materiais digitais, por meio do website consultado com a data de acesso.

Consideramos que, embora a produção do programa caracterize bem as fontes em termos de publicação (periódicos, editoras, anos e etc), ainda carece de maior detalhamento em relação ao modo que se deu a busca pelas fontes. Certamente isso inclui também uma maior discussão sobre as dificuldades encontradas na obtenção das fontes que, atualmente, é pouco presente.

Embora dirijamos essa crítica aos trabalhos, ressaltamos que não esperávamos trabalhos com o mesmo rigor e detalhamento historiográfico no que se refere ao tratamento das fontes, que normalmente encontra-se em trabalhos produzidos na área de história da ciência. Entretanto, consideramos que é relevante uma maior sistematização na descrição da utilização das fontes.

\subsubsection{Idiomas}

Em relação aos idiomas, expressaremos nossas descobertas através da divisão entre fontes primárias e secundárias. Para as fontes primárias utilizadas, encontramos a distribuição de idiomas na utilização de tais materiais: 
Gráfico 4 - Idiomas de utilização das fontes primárias

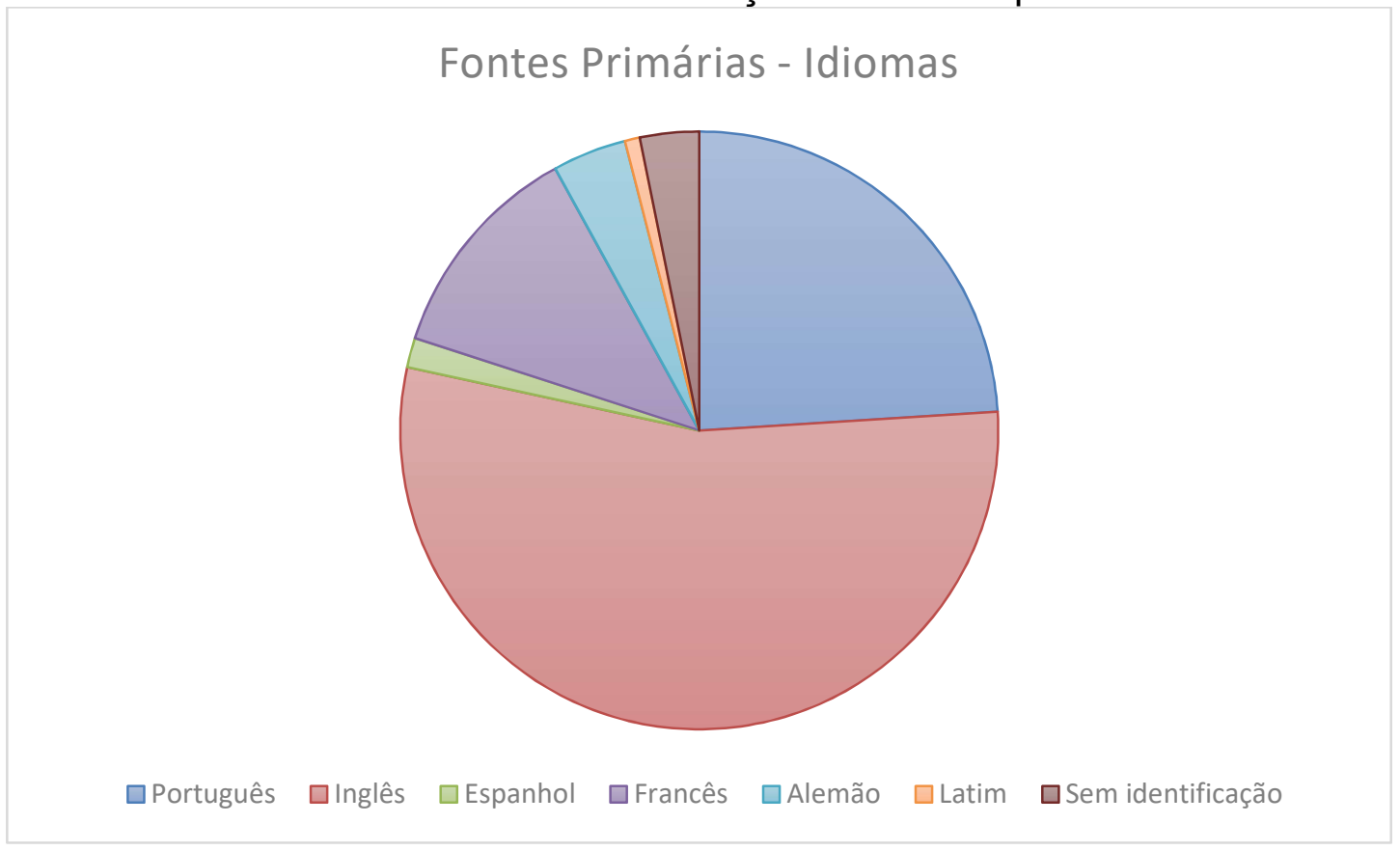

Fonte: Autoria própria com base nos dados analisados.

Nota-se, portanto, uma predominância de materiais na língua inglesa e portuguesa, seguida por materiais em língua francesa. Como as fontes primárias se tratam basicamente de materiais produzidos pelos personagens ligados diretamente ao período estudado, uma das explicações para a predominância da língua inglesa é justamente a preferência pela tradução e publicação de materiais originais nessa língua. Há alguns exemplos de materiais produzidos em outras línguas e publicados em língua inglesa: Mozena (2003), autora do trabalho 13, utiliza um livro e uma autobiografia traduzidas para o inglês de Max Planck, um importante cientista alemão; Campos (2014), autor do trabalho 22, utiliza um capítulo de livro de Nicolas Carnot, um físico francês. Além disso, há também alguns materiais produzidos por cientistas ingleses e utilizados em sua língua original, como os materiais de Michael Faraday, utilizados por Gardelli (2004) no trabalho 14 e os materiais escritos por James Joule, consultados por Higa (1987).

Algo semelhante acontece com os materiais consultados na língua francesa, especialmente nos trabalhos que tratam das teorias termodinâmicas. Aurani (1986), autora do trabalho 1, utilizou dois artigos de Nicolas Carnot, um dos personagens mais conhecidos da termodinânica. Essas fontes foram consultadas em sua língua original (francês), obtidas através de fac-símile e uma compilação. Essa mesma compilação foi utilizada pelo autor do trabalho 21 (SILVA, 2013). Além de citar essa 
fonte primária, ele cita outras obras de autores franceses, como Joseph-Louis Lagrange e Pierre Duhem. Algumas obras foram traduzidas de sua língua original para o francês, como as cartas de Einstein utilizadas por Gurgel (2006) ao escrever o trabalho 16.

As fontes primárias consultadas na língua portuguesa são, em sua grande maioria, traduções de livros e artigos produzidos por figuras conhecidas da ciência. Gurgel (2006), autor do trabalho 16, utilizou uma autobiografia traduzida de Einstein, além de dois artigos e um livro. Arruda (1994), autor do trabalho 7, investigou o surgimento da Teoria da Relatividade Especial em uma perspectiva estritamente internalista, se utilizando de quatro artigos traduzidos de Albert Einstein. Alguns outros cientistas "famosos" tiveram suas obras traduzidas e utilizadas nas teses e dissertações analisadas, como Niels Bohr e Werner Heisenberger (fontes utilizadas no trabalho 5 (FREIRE JUNIOR, 1991)), Isaac Newton e Jules Poincaré (fontes utilizadas no trabalho 11 (OLIVEIRA, 2001) e Max Born (fonte utilizada no trabalho 12 (DONADELLI, 2002)).

De modo semelhante, construímos também um gráfico indicando as tendências da utilização de determinados idiomas para as fontes secundárias:

Gráfico 5 - Idiomas de utilização das fontes secundárias

\section{Fontes Secundárias - Idiomas}

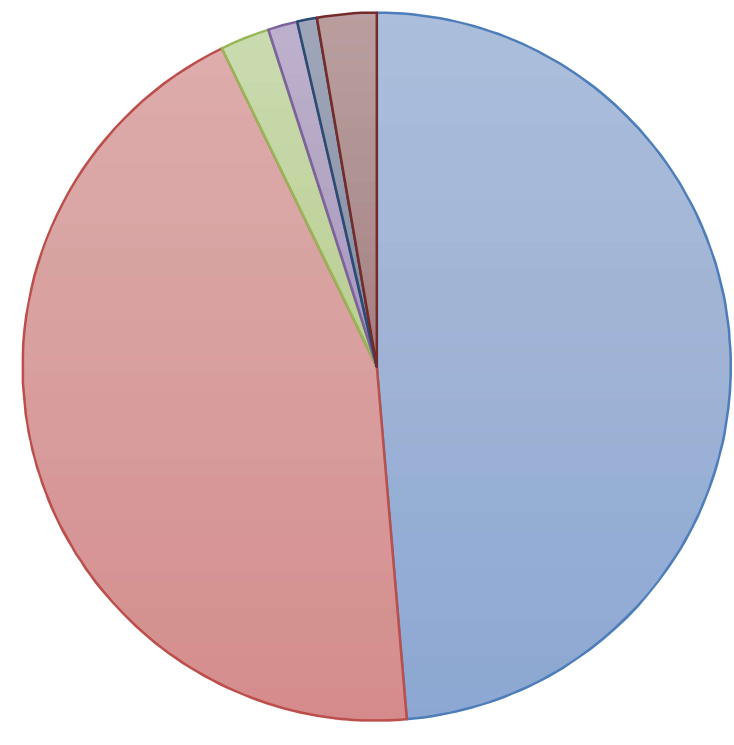

$\square$ Português $\square$ Inglês $\square$ Espanhol $\square$ Francês $\square$ Italiano

$\square$ Sem identificação

Fonte: Autoria própria com base nos dados analisados.

A diferença reside, essencialmente, em uma utilização mais recorrente dos 
materiais em língua portuguesa e inglesa, que juntos correspondem praticamente à totalidade dos idiomas utilizados nas fontes secundárias. Agora, embora ainda seja relevante a tradução de materiais para a língua portuguesa, os autores também apresentam maior uso de materiais nacionais, demonstrando também uma presença relevante da área de história da ciência no Brasil.

Uma consideração importante a ser feita em relação aos idiomas consultados é que, diferentemente da indicação dos materiais físicos ou digitais, o modo como os autores indicam as fontes consultadas dão menos espaços a imprecisões. De modo geral, quando explicitada a fonte utilizada, o próprio título já carrega o idioma.

Entretanto, apesar dessa precisão na indicação dos idiomas, é possível dirigir uma crítica referente à consulta em diferentes idiomas. Em nenhum dos trabalhos analisados notamos a presença de uma preocupação em comparar diferentes traduções ou de fazer considerações sobre a presença de traduções de baixa fidedignidade. Em vários casos (que não mensuramos), há a indicação do(a) tradutor(a), mas em nenhum caso encontramos considerações sobre a qualidade da tradução.

Finalizando nossas considerações sobre os idiomas utilizados pelos autores, é relevante citar que o PIEC há alguns anos filtra seus candidatos também pelo idioma. Dessa forma, pode-se dizer que há uma tentativa explícita de garantir que os pesquisadores sejam capazes de se relacionar com o inglês, ampliando, assim, a possibilidade de utilizar materiais publicados neste idioma..

\subsection{Fontes e ensino}

O terceiro foco de interesse principal desse trabalho é a investigação sobre a existência de algum tipo de relação entre a utilização das fontes e o ensino de física. De modo geral, antes de iniciar a pesquisa, imaginamos que algumas produções carregariam consigo também ideias de como utilizar tais materiais no ensino de física. Entretanto, nossa análise confirma que a maior parte dos trabalhos, embora produzam textos historiográficos, não propõe nenhuma intervenção com as fontes diretamente no ensino.

O enfoque dos trabalhos, conforme pudemos obter através da análise proposta, é a construção de relatos historiográficos. Dessa forma, a utilização das fontes históricas é parte exclusivamente da metodologia de pesquisa historiográfica empregada, uma vez que nenhum dos trabalhos apresentou uma proposta de ensino 
que utilizasse diretamente essas fontes. A principal justificativa para a utilização das fontes é, portanto, uma pretensão de fidedignidade para a construção de relatos historiográficos que apresentam uma visão crítica do processo de desenvolvimento do conhecimento científico. Selecionamos alguns exemplos que mostram esse ponto de vista:

O estudo da História da Ciência pode ajudar o professor a complementar os aspectos puramente técnicos de uma aula com aspectos sociais, humanos e culturais de uma época; pode fornecer informações sobre a vida dos cientistas e seus eventuais êxitos e fracassos; pode abordar as concepções alternativas de um certo período e as controvérsias e dificuldades de aceitação de novas ideias; [...] e também pode permitir uma visão crítica da origem e evolução dos conceitos científicos (T14. GARDELLI, 2004, p. 2, grifos nossos)

Neste capítulo será apresentada a controvérsia entre a teoria do Big Bang e a teoria do Estado Estacionário. Este foi o episódio histórico escolhido para conduzir discussões sobre relações entre ciência e visões de mundo, porque permite a investigação da influência de aspectos filosóficos e religiosos na construção de teorias cosmológicas entre as décadas de 1940 e 1960. (T19, HENRIQUE, 2015, p. 67, grifos nossos)

Explorando dessa maneira, pretendemos trazer uma visão de história mais completa e menos ingênua, fugindo da pseudo-história, muito presente em manuais didáticos e em alguns dos livros de divulgação consultados nessa pesquisa. (T17, BARCELLOS, 2008, p. 57, grifos nossos)

Uma conclusão retirada diretamente da análise desses materiais é que a inserção da história da ciência no ensino visa muito mais uma ampliação da visão de ciência pelos estudantes do que um ensino de ciências que seja pautado pela historiografia, o que inclui o trabalho com fontes.

A análise do impacto das fontes no ensino é restrita, uma vez que mapear qual a exata influência (ou até mesmo chegar próximo do entendimento dessa influência) exigiria um estudo de outra natureza que não a desse trabalho. Como análise documental, propositalmente analisamos o discurso escrito. $E$, nesse ponto, não encontramos proposições dessa natureza através desse tipo de discurso. 


\section{CONCLUSÃO: CARACTERIZAÇÃO DE UM ASPECTO DO PROGRAMA}

Nesse ponto final desse trabalho e com a quantidade de dados analisados, gostaríamos de propor algumas conclusões e uma caracterização geral da produção do programa. Para tanto, dividimos a escrita dessa parte final em dois tópicos: o primeiro é uma reflexão da própria análise de relatos historiográficos o segundo é uma caracterização geral dos trabalhos que analisamos.

\subsection{A historiografia dos trabalhos}

Do ponto de vista historiográfico, pudemos notar a predominância de algumas características que fazem parte dessa caracterização geral que estamos propondo. Conforme insistimos no decorrer do desenvolvimento desse trabalho, a abordagem desse grupo de trabalhos é próxima ao internalismo, mas incluindo algumas breves considerações sobre os variados contextos das diferentes épocas estudadas. A produção do programa não é, então, completamente internalista; pode ser considerada mais próxima dessa abordagem, mas que compreende que outros fatores são também relevantes.

É possível considerar, a partir das análises, da leitura de referenciais diversos e do contraste entre algumas "tradições" diferentes, que alguns fatores constroem essa tendência do programa. Dentre tais fatores, cremos que as principais influências construídas dentro da área são ligadas ao valor de verdade das proposições científicas e da relevância "quase exclusiva" de sua lógica interna. O tratamento majoritário desses aspectos é convergente com a própria defesa da $\mathrm{HC}$ na área de Ensino, que visa, dentre outras coisas, um entendimento maior dos processos de construção de conhecimento científico.

\subsection{As fontes utilizadas no PIEC}

De modo geral, podemos listar as nossas descobertas em relação as fontes utilizadas pelos autores do PIEC da seguinte forma:

1) Nota-se uma predominância do uso de fontes secundárias em relação às fontes primárias. Nossa interpretação é que os fatores para essa escolha são referentes à facilidade de encontrar e lidar com fontes secundárias. Além disso, como 
visto em alguns exemplos no capítulo anterior, alguns autores associam a predominância do uso de fontes secundárias como uma simplificação do trabalho historiográfico, dando sentido ao relato histórico como parte de um trabalho maior (como visto em T17 e T19, por exemplo).

2) Embora haja diferenças entre as fontes primárias e secundárias, notamos que os autores tendem a utilizar um número maior de artigos e livros em relação a outras modalidades de fontes. Em nossa interpretação, vários fatores podem justificar estas escolhas, como a própria facilidade de encontrar tais fontes, que, em sua maioria, têm caráter público. Além disso, são modalidades discursivas mais comuns dentro das áreas acadêmicas, sejam elas física, história da ciência ou ensino de ciências. Por último, ressaltamos que é possível também identificar uma correlação entre o uso dessas fontes e a escolha internalista. Através dessas fontes que tratam mais dos aspectos teóricos e, eventualmente metodológicos das teorias científicas, é possível tratar das especificidades internas do objeto de estudo.

3) Os autores, de modo geral, lidam bem com fontes na língua inglesa, havendo um predomínio do uso de fontes em língua portuguesa e inglesa. No caso das fontes primárias, a língua inglesa é predominante uma vez que a produção original dos cientistas, de modo geral, é feita nesse idioma. No caso das fontes primárias em língua portuguesa, constatamos que tratam-se, principalmente, de traduções de textos clássicos produzidos por cientistas mais conhecidos. Em relação às fontes secundárias, a língua portuguesa é predominante, evidenciando uma existência em boa quantidade de materiais historiográficos em língua portuguesa.

4) Em relação ao acesso às fontes, notamos que, embora tenhamos certa precisão no entendimento do idioma utilizado, muito pouco é refletido ou dito sobre as dificuldades de acesso. Poucas menções sobre o acesso a fontes digitalizadas ou acessadas fisicamente.

$\mathrm{E}$, por último, como uma contribuição específica à área de ensino de ciências, concluímos que há um papel bastante relevante das fontes para o ensino, principalmente através de seu uso na construção de relatos historiográficos, que servem a diferentes fins no ensino de ciências.

Notamos, pois, que este é o principal fim dessas fontes. Pouco se diz da adaptação de materiais historiográficos para aplicação direta no ensino, mas muito tem se desenvolvido em relação à importância da história da ciência no ensino.

Com esse trabalho esperamos ter oferecido uma pequena contribuição à área de 
ensino de ciências, em especial aos futuros pesquisadores que tenham intenção de trabalhar na interface entre HC e EC. Além disso, esperamos também ter lançado um pouco de luz sobre a produção do PIEC, no que se refere a esse aspecto específico. 


\section{REFERÊNCIAS BIBLIOGRÁFICAS}

AITCHISON, Jean. Language Change: Progress or Decay? Nova lorque: Cambridge University Press, 2001

ASSIS, Kleyson R. História e filosofia da ciência no ensino de ciências e o debate universalismo versus relativismo. Revista Brasileira de História da Ciência, v. 7, n. 2. 2014.

BAGHRAMIAN, Maria; CARTER, J. Adam. Relativism. The Stanford Encyclopedia of Philosophy. 2015.2 Disponível em: https://plato.stanford.edu/archives/win2019/entries/relativism/, acesso em janeiro de 2020.

BAKHTIN, Mikhail. Os gêneros do discurso. Tradução de Paulo Bezerra. 1 ed. São Paulo: Editora 34, 2016.

BRAIT, Beth; MELO, Rosineide de. Enunciado/enunciado concreto/enunciação. In: BRAIT, B. (Org.) Bakhtin: conceitos-chave. São Paulo: Contexto, 2005.

BURKE, Peter. O que é História do Conhecimento? Tradução de Claudia Freire. 1 ed. São Paulo: Editora UNESP, 2015.

CANIATO, Rodolpho. Um projeto brasileiro para o Ensino de Física. 1973. 586f. Tese (Doutorado) do Programa de Pós-Graduação em Física. Universidade Estadual Paulista Julio de Mesquita Filho - campus Rio Claro, 1973.

DIAS, 2008. História e Filosofia da Ciência na pesquisa em Ensino de Ciências no Brasil: manutenção de um mito? 2008. 116f. Tese (Doutorado) do Programa de PósGraduação em Educação para a Ciência. Universidade Estadual Paulista Julio de Mesquita Filho - campus Bauru, 2008.

FERES, Glória Georges; NARDI, Roberto. A Pós-Graduação em Ensino de Ciências no Brasil: contribuição teórico-analítica sobre panorama histórico e o perfil dos cursos. In: NARDI, R.; GONÇALVES, T. V. O. (Org.) A Pós-Graduação em Ensino de Ciências e Matemática do Brasil: memórias, programas e consolidação da pesquisa na área. São Paulo: Editora Livraria da Física, 2014.

FIORIN, José Luiz. Introdução ao Pensamento de Bakhtin. 1 ed. São Paulo: Contexto, 2006.

GAVROGLU, Kostas. O Passado das Ciências como História. Porto: Porto Editora, 2007. 
GUERRINI, Anita. Translation as a Way of Life. Isis 109, n. 4, 2018. Disponível em: https://www.journals.uchicago.edu/doi/full/10.1086/701245. Acesso em janeiro de 2020.

HACKING, lan. Representar e intervir: tópicos introdutórios de filosofia da ciência natural. 1 ed. Rio de Janeiro: Editora da Universidade Estadual do Rio de Janeiro, 2017.

HOBSBAWM, Eric. Era dos Extremos: o breve século XX (1914 - 1991). 2 ed. São Paulo: Companhia das Letras, 1995.

HUNT, Bruce J. Os Seguidores de Maxwell. Belo Horizonte: Editora UFMG, 2015. KNORR-CETINA, Karin. A comunicação na ciência. In: GIL, F. (org.) A Ciência tal qual se Faz. Lisboa: Edições João Sá da Costa, 1999.

KRAGH, Helge. An Introduction to the Historiography of Science. 1 ed. New York: Cambridge University Press, 1987.

KRASILCHIK, Myriam. Reformas e Realidade: O caso do ensino das ciências. São Paulo em Perspectiva, v. 14, n. 1, p 85 - 93. 2000.

KUHN, Thomas S. A História da Ciência. In: KUHN, Thomas S. A Tensão Essencial: Estudos Selecionados Sobre Tradição e Mudança Científica. São Paulo: Editora Unesp, 2011.

KUHN, Thomas S. A Estrutura das Revoluções Científicas. 13 ed. São Paulo: Pesrpectiva, 2017.

LATOUR, Bruno. A Esperança de Pandora: ensaios sobre a realidade dos estudos científicos. São Paulo: Editora Unesp, 2017.

LE GOFF, Jacques. História e Memória. São Paulo: Editora Unicamp, 1994.

MACHADO, Irene. Gêneros discursivos. In: BRAIT, B. (Org.) Bakhtin: conceitoschave. São Paulo: Contexto, 2005.

MAGALHÃES, Gildo; SALATEO, Rosiney. História da ciência e crescimento econômico: a produção de artigos de história da química em periódicos brasileiros (1974-2004). Revista Brasileira de História da Ciência, v. 8, nº 2, p. 16 - 25.

MARTINS, Lilian Al-Chueyr Pereira. História da Ciência: objetos, métodos e problemas. Ciência \& Educação, v. 11, n. 3, p. 305-317, 2005.

MARTINS, Roberto de Andrade. Ciência versus historiografia: os diferentes níveis discursivos nas obras sobre História da Ciência. In: ALFONSO-GOLDFARB, A. M.; BELTRAN, M. H. R. (Org.) Escrevendo a História da Ciência: tendências, propostas e 
discussões historiográficas. São Paulo: Editora da PUC, 2004.

MATTHEWS, Michael. História, filosofia e ensino de ciências: a tendência atual de reaproximação. Caderno Brasileiro de Ensino de Física, v. 12, n 3, 1995.

MEGID NETO, Jorge. Origem e desenvolvimento do campo de pesquisa em Educação em Ciências no Brasil. In: NARDI, R.; GONÇALVES, T. V. O. (Org.) A Pós-Graduação em Ensino de Ciências e Matemática do Brasil: memórias, programas e consolidação da pesquisa na área. São Paulo: Editora Livraria da Física, 2014.

MOREIRA, Marco Antonio. Ensino de Física no Brasil: retrospectiva e perspectivas. Revista Brasileira do Ensino de Física, v. 22, n. 1, 2000.

MOTTA, Rodrigo Patto Sá. A Ditadura nas universidades: repressão, modernização e acomodação. Ciência e Cultura, v. 66 n 4. 2014.

NARDI, Roberto. A área de Ensino de Ciências no Brasil: fatores que determinaram sua constituição e suas características segundo pesquisadores brasileiros. 2005. 166f. Tese (Livre Docência), Universidade Estadual Paulista, Bauru.

OGILVIE, Brian. Scientific Archives in the Age of Digitization. Isis 107, $\mathrm{n}^{\circ}$ 1. 2016. Disponível em: https://www.journals.uchicago.edu/doi/full/10.1086/686075, acesso em janeiro de 2020.

PENA, Fábio Luís Alves. Sobre a presença do projeto Harvard no sistema educacional brasileiro. Revista Brasileira de Ensino de Física, v. 34, nº 1. 2012.

PONTES, Luís A. Fajardo. O movimento norte-americano de reforma educacional: sinopse de sua evolução, desafios e associação com as habilidades do século 21. Pesquisa e Debate em Educação, v. 4, nº 1. 2014.

SALÉM, Sônia. Perfil, evolução e perspectivas da Pesquisa em Ensino de Física no Brasil. 2012. 385f. Tese (Doutorado), Universidade de São Paulo, São Paulo.

SILVA, Francismary Alves da. Descoberta versus Justificativa: a Sociologia e a Filosofia do conhecimento científico na primeira metade do Século XX. Revista de Teoria da História, v. 2, n² 2. 2009.

SOCIEDADE BRASILEIRA DE FÍSICA. Boletim $n^{\circ} 4$ - Simpósio Nacional sobre o Ensino de Física. Salvador, 1970.

VIDEIRA, Antônio A. P. Historiografia e História da Ciência. Escritos, n 1. 2007. VILLANI, Alberto; PACCA, Jesuína Lopes de Almeida; FREITAS, Denise de. Science Teacher Education in Brazil: 1950-2000. Science \& Education, v. 18, nº 1, p $125-$ 148. 2009. 


\section{APÊNDICE A}

\section{TRABALHOS DO PIEC NA INTERFACE ENTRE HISTÓRIA DA CIÊNCIA E ENSINO}

\section{Teses de doutorado}

\section{6}

CARVALHO, Tassiana Fernanda Genzini de. Da divulgação ao ensino: um olhar para o céu. Orientado por Jesuína Lopes de Almeida Pacca.

SCHMIEDECKE, Winston Gomes. A história da ciência nacional na formação e na prática de professores de física. Orientado por Paulo Alves Porto.

\section{5}

HENRIQUE, Alexandre Bagdonas. Controvérsias envolvendo a natureza da ciência da ciência em sequências didáticas sobre cosmologia. Orientado por João Zanetic.

\section{4}

CAMPOS, Alexandre. A conceitualização do princípio de conservação da energia mecânica: os processos de aprendizagem e a teoria dos campos conceituais.

Orientado por Elio Carlos Ricardo.

\section{3}

SILVA, Djalma Nunes da. Ensino e aprendizagem da termodinâmica: questões didáticas e contribuições da história da ciência. Orientado por Jesuína Lopes de Almeida Pacca.

2012

Não há

\section{Dissertações de Mestrado}

Os trabalhos de 2017 ainda não haviam sido catalogados na ocasião da consulta.

\section{6}

Não há 2015

SCHUTT, Kléber Roberto. O diálogo entre a física e a arte no renascimento:

construindo uma proposta interdisciplinar envolvendo o estudo de pontes no ensino médio. Orientado por João Zanetic.

LUIZ, Danilo Cardoso Rodrigues. A complementariedade dos pensamentos narrativo e matemático na gestação da teoria da relatividade geral. Orientado por Ivã Gurgel. 
2014

SKOLIMOSKI, Kellen Nunes. Cosmologia na teoria e na prática: possibilidades e limitações no ensino. Orientado por João Zanetic.

MOREIRA, André Batista Noronha. Interpretando a relatividade especial: discutindo o debate realismo e antirrealismo científicos no ensino de ciências. Orientado por Ivã Gurgel.

2013

Não há

2012

ALBUQUERQUE, Vanessa Nóbrega de. O caso Plutão e a natureza da ciência: uma proposta para alunos do ensino médio. Orientado por Cristina Leite.

2011

HENRIQUE, Alexandre Bagdonas. Discutindo a natureza da ciência a partir de episódios da história da cosmologia. Orientado por Cibelle Celestino Silva.

2010

PEREIRA, Rafael Andrade. A física da música no Renascimento: uma abordagem histórico-epistemológica. Orientado por Oscar João Abdounur.

2009

SILVA, Djalma Nunes da. A termodinâmica no ensino médio: ênfase nos processos irreversíveis. Orientado por Jesuína Lopes de Almeida Pacca.

BUENO, Maria Christina Fernandes. Os textos originais para ensinar conceitos de mecânica. Orientado por Jesuína Lopes de Almeida Pacca.

ANDREIS, Ulisses Antônio. Uma ligação entre a teoria da peça didática de Brecht, pedagogia de Paulo Freire e o Ensino de Física. Orientado por João Zanetic.

\section{8}

SOUZA, Paulo Henrique de. Tempo, Ciência, História e Educação: um diálogo entre a Cultura e o Perfil Epistemológico. Orientado por João Zanetic.

MOURA, Breno Arsioli. A aceitação da óptica newtoniana no século XVIII: subsídios para discutir a Natureza da Ciência do Ensino. Orientado por Cibelle Celestino Silva. BARCELLOS, Marcília Elis. História, sociologia, massa e energia: Uma reflexão sobre a formação de pesquisadores em física. Orientado por João Zanetic.

\section{7}

Não há. 


\section{6}

GURGEL,Ivã. A imaginação científica como componente do entendimento: subsídios para o ensino de física. Orientado por Maurício Pietrocola Pinto de Oliveira.

CARVALHO, Silvia Helena Mariano. Ciência e arte, razão e imaginação complementos necessários ao ensino de uma nova física. Orientado por João Zanetic.

\section{5}

DELGADO, Nely Magdalena Barrios. Concepções alternativas e conhecimento científico: contribuições para o problema da incompatibilidade teórica em ensino de ciências. Orientado por Norberto Cardoso Ferreira.

\section{4}

GARDELLI, Daniel. Concepções de interação física: Subsídios para uma abordagem histórica do assunto no ensino médio. Orientado por Roberto de Andrade Martins.

DIAS, Valéria Silva. Michael Faraday: subsídios para metodologia de trabalho experimental. Orientado por Alberto Villani.

\section{3}

MOZENA, Erika Regina. A solução de Planck para o problema da radiação do corpo negro (PRCN) e o ensino de física quântica. Orientado por João Zanetic.

\section{2}

DONADELLI, Marisilvia. Exercícios de compreensão da mecânica quântica, de seus fenômenos de correlação à distância e possíveis aplicações. Orientado por Amélia Império Hamburger.

\section{1}

OLIVEIRA, Ana Maria de. Pode o ensino de física prescindir da matemática? respostas em estudos históricos e epistemológicos. Orientado por Amélia Império Hamburger.

1999 e 2000

Não há

1998

ARAÚJO FILHO, Walter Duarte de. Galileu e a Queda de Corpos: Conteúdo Veiculado nos Livros Didáticos de Física do $2^{\circ} \mathrm{Grau}$ : Uma Abordagem Crítica. Orientado por Norberto Cardoso Ferreira. 
MARTINS, André Ferrer Pinto. O Ensino do Conceito de Tempo: Contribuições Históricas e Epistemológicas. Orientado por João Zanetic.

SILVA, Joselina Conceição da. Um exemplo do uso da História e Filosofia da Física: Disciplina FEP156 - Gravitação. Orientado por João Zanetic.

1997

FAGUNDES, Maria Beatriz. Ensinando a Dualidade Onda-Partícula sob uma nova Óptica. Orientado por João Zanetic.

VANNUCCHI, Andrea Infantosi. História e Filosofia da Ciência: da Teoria para a Sala de Aula. Orientado por Anna Maria Pessoa de Carvalho.

\section{6}

HENRIQUE, Katia Ferreira. O Pensamento Físico e o Pensamento do Senso

Comum: a Energia no $2^{\circ}$ grau. Orientado por Jesuína Lopes de Almeida Pacca.

1995

KAMIOJI, Marly Ivo. Ser sendo: a Energia que se conserva ao se transformar Análise de situações da emergência do conceito de Energia na aprendizagem em Exposição Científica. Orientado por Amélia Império Hamburger.

SIMÕES, Armando Amorim. A Concepção Dialética do Conhecimento e o Ensino de Física. Orientado por João Zanetic.

1994

LARANJEIRAS, Cássio Costa.Redimensionando o Ensino de Física numa perspectiva histórica. Orientado por João Zanetic.

ARRUDA, Sérgio de Mello. Mudança conceitual na Teoria da Relatividade Especial. Orientado por Manoel Roberto Robilotta.

1993

OLIVEIRA, Margareth Miranda de. O "Átomo": da conceituação indutiva grega à realização quantitativa europeia. Orientado por Amélia Império Hamburger.

CASTRO, Ruth Schmitz de. História e Epistemologia da Ciência: investigando suas contribuições num curso de física de segundo grau. Orientado por Anna Maria Pessoa de Carvalho.

BATISTA, Irinéa de Lourdes. A concepção física de Espaço e o ensino de Mecânica. Orientado por Maria Regina Dubeux Kawamura.

1992

Não há 
1991

MARDEGAN, Luiz Augusto. Um estudo das origens conceitual e matemática do Princípio da Mínima Ação. Orientado por Amélia Império Hamburger.

MATTOS, Cristiano Rodrigues de. Entrando na Era de ensino de Entropia. Orientado por Amélia Império Hamburger.

FREIRE JÚNIOR, Olival. Estudo sobre interpretações (1927 - 1949) da Teoria Quântica: Epistemologia e Física. Orientado por Amélia Império Hamburger. 1990

Não há.

1989

ABRAMOF, Patrícia Guimarães. Um estudo do Opticks de Newton - Aspectos do pensamento Newtoniano e dos seus métodos de trabalhar em Física. Orientado por Amélia Império Hamburger.

VERDEAUX, Maria de Fátima da Silva. Evolução história do Conhecimento, utilização e aplicação dos Raios-X: a relação entre Ciência, Tecnologia e Sociedade. Orientado por Jesuína Lopes de Almeida Pacca.

1988

RODRIGUES, Idely Garcia. Aspectos epistemológicos da Mecânica de Newton. Orientado por Amélia Império Hamburger.

HIGA, Teresinha Teruko. Conservação de Energia: estudo histórico e levantamento conceitual dos alunos. Orientado por Ernst Wolfgang Hamburger.

ALBUQUERQUE, Ivone Freire de Mota e. Entropia e Quantização da Energia: cálculo termodinâmico de Planck. Orientado por Amélia Império Hamburger. 1987

SOUZA FILHO, Oswaldo Melo. Evolução da ideia de Conservação de Energia - um exemplo de História da Ciência no Ensino de Física. Orientado por Manoel Roberto Robilotta.

ROVIGATTI, Rodinei Lourenço. O papel da explicação causal no Ensino de Física. Orientado por Alberto Villani.

1986

AURANI, Katya Margareth. Ensino de conceitos: estudo das origens da $2^{\mathrm{a}}$ Lei da Termodinâmica e do Conceito de Entropia a partir do Século XVIII. Orientado por Ernst Wolfgang Hamburger. 
1985

Não há.

1984

MEDEIROS, Alexandre José Gonçalves. Condicionantes históricos e sociais no surgimento da Física (um guia e um guia bibliográfico para professores de física). Orientado por Luís Carlos de Menezes.

1983, 1982, 1980, 1978, 1979, 1978, 1977 - Não há 


\section{APÊNDICE B}

\section{TRABALHOS ANALISADOS PARA A CONSTRUÇÃO DESSE TRABALHO}

CARVALHO, Tassiana Fernanda Genzini de. Da divulgação ao ensino: um olhar para o céu. Orientado por Jesuína Lopes de Almeida Pacca.

CAMPOS, Alexandre. A conceitualização do princípio de conservação da energia mecânica: os processos de aprendizagem e a teoria dos campos conceituais. Orientado por Elio Carlos Ricardo.

SILVA, Djalma Nunes da. Ensino e aprendizagem da termodinâmica: questões didáticas e contribuições da história da ciência. Orientado por Jesuína Lopes de Almeida Pacca.

LUIZ, Danilo Cardoso Rodrigues. A complementariedade dos pensamentos narrativo e matemático na gestação da teoria da relatividade geral. Orientado por Ivã Gurgel. ALBUQUERQUE, Vanessa Nóbrega de. O caso Plutão e a natureza da ciência: uma proposta para alunos do ensino médio. Orientado por Cristina Leite.

HENRIQUE, Alexandre Bagdonas. Discutindo a natureza da ciência a partir de episódios da história da cosmologia. Orientado por Cibelle Celestino Silva.

PEREIRA, Rafael Andrade. A física da música no Renascimento: uma abordagem histórico-epistemológica. Orientado por Oscar João Abdounur.

BARCELLOS, Marcília Elis. História, sociologia, massa e energia: Uma reflexão sobre a formação de pesquisadores em física. Orientado por João Zanetic.

GURGEL, Ivã. A imaginação científica como componente do entendimento: subsídios para o ensino de física. Orientado por Maurício Pietrocola Pinto de Oliveira. DELGADO, Nely Magdalena Barrios. Concepções alternativas e conhecimento científico: contribuições para o problema da incompatibilidade teórica em ensino de ciências. Orientado por Norberto Cardoso Ferreira.

GARDELLI, Daniel. Concepções de interação física: Subsídios para uma abordagem histórica do assunto no ensino médio. Orientado por Roberto de Andrade Martins. MOZENA, Erika Regina. A solução de Planck para o problema da radiação do corpo negro (PRCN) e o ensino de física quântica. Orientado por João Zanetic.

DONADELLI, Marisilvia. Exercícios de compreensão da mecânica quântica, de seus fenômenos de correlação à distância e possíveis aplicações. Orientado por Amélia Império Hamburger. 
OLIVEIRA, Ana Maria de. Pode o ensino de física prescindir da matemática? respostas em estudos históricos e epistemológicos. Orientado por Amélia Império Hamburger.

ARAÚJO FILHO, Walter Duarte de. Galileu e a Queda de Corpos: Conteúdo Veiculado nos Livros Didáticos de Física do $2^{\circ}$ Grau: Uma Abordagem Crítica. Orientado por Norberto Cardoso Ferreira.

FAGUNDES, Maria Beatriz. Ensinando a Dualidade Onda-Partícula sob uma nova Óptica. Orientado por João Zanetic.

HENRIQUE, Katia Ferreira. O Pensamento Físico e o Pensamento do Senso Comum: a Energia no $2^{\circ}$ grau. Orientado por Jesuína Lopes de Almeida Pacca.

SIMÕES, Armando Amorim. A Concepção Dialética do Conhecimento e o Ensino de Física. Orientado por João Zanetic.

ARRUDA, Sérgio de Mello. Mudança conceitual na Teoria da Relatividade Especial. Orientado por Manoel Roberto Robilotta.

BATISTA, Irinéa de Lourdes. A concepção física de Espaço e o ensino de Mecânica. Orientado por Maria Regina Dubeux Kawamura.

FREIRE JÚNIOR, Olival. Estudo sobre interpretações (1927 - 1949) da Teoria Quântica: Epistemologia e Física. Orientado por Amélia Império Hamburger.

VERDEAUX, Maria de Fátima da Silva. Evolução história do Conhecimento, utilização e aplicação dos Raios-X: a relação entre Ciência, Tecnologia e Sociedade. Orientado por Jesuína Lopes de Almeida Pacca.

ROVIGATTI, Rodinei Lourenço. O papel da explicação causal no Ensino de Física. Orientado por Alberto Villani.

HIGA, Teresinha Teruko. Conservação de Energia: estudo histórico e levantamento conceitual dos alunos. Orientado por Ernst Wolfgang Hamburger.

AURANI, Katya Margareth. Ensino de conceitos: estudo das origens da $2^{\text {a }}$ Lei da Termodinâmica e do Conceito de Entropia a partir do Século XVIII. 